Florida International University FIU Digital Commons

4-1-2004

\title{
Kit-of-parts architecture : an exploration into the standardization and simplification of an urban residential building unit
}

John Anderson Allmand

Florida International University

DOI: $10.25148 /$ etd.FI13101593

Follow this and additional works at: https://digitalcommons.fiu.edu/etd

Part of the Urban, Community and Regional Planning Commons

\section{Recommended Citation}

Allmand, John Anderson, "Kit-of-parts architecture : an exploration into the standardization and simplification of an urban residential building unit" (2004). FIU Electronic Theses and Dissertations. 1070.

https://digitalcommons.fiu.edu/etd/1070 
FLORIDA INTERNATIONAL UNIVERSITY

Miami, Florida

KIT-OF-PARTS ARCHITECTURE:

AN EXPLORATION INTO THE STANDARDIZATION

AND SIMPLIFICATION OF AN URBAN

RESIDENTIAL BUILDING UNIT

A thesis submitted in partial fulfillment of the

requirements for the degree of

MASTER OF ARCHITECTURE

by

John Anderson Allmand 
This thesis, written by John Anderson Allmand, and entitled Kit-of-Parts Architecture: An Exploration into the Standardization and Simplification of an Urban Residential Building Unit, having been approved in respect to style and intellectual content, is referred to you for judgment.

We have read this thesis and recommend that it be approved.

Gray Read

'William McMinn

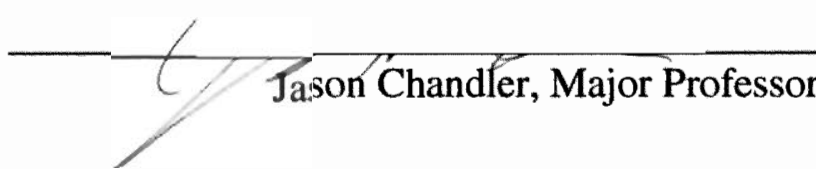

Date of Defense: April 1, 2004

The thesis of John Anderson Allmand is approved.

Dean Juan Antonio Bueno School of Architecture

Dean Douglas Wartzok University Graduate School 
(C) Copyright 2004 by John Anderson Allmand All rights reserved. 
DEDICATION

I dedicate this thesis to Christine, who inspires me to excel at everything I do. 
ABSTRACT OF THESIS

KIT-OF-PARTS ARCHITECTURE:

AN EXPLORATION INTO THE STANDARDIZATION

AND SIMPLIFICATION OF AN URBAN

RESIDENTIAL BUILDING UNIT

by

John Anderson Allmand

Florida International University

Miami, Florida

Professor Jason Chandler, Major Professor

This thesis focuses on the design of a construction method that utilizes a single adaptable kit-of-parts system. The new system is designed to be flexible while also enhancing construction speeds without severely limiting the building's ability to merge into an urban fabric. This thesis proposes a residential structure to be built from a handful of simple structural units.

This is accomplished through the design of a residential building situated in an area of Miami currently under reconstruction. 


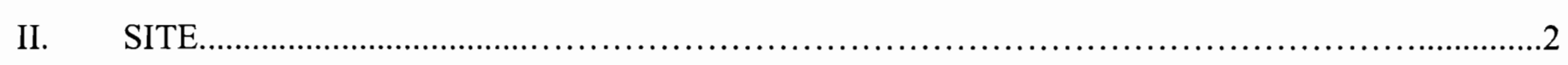

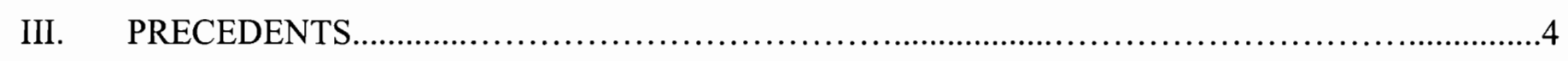

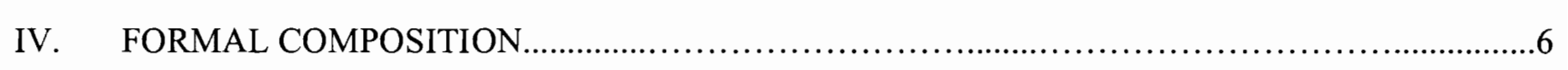

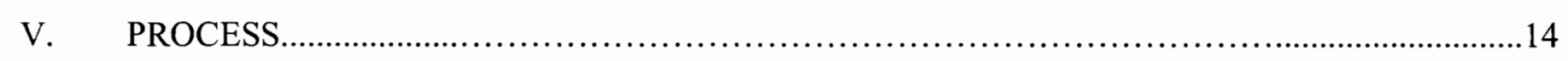

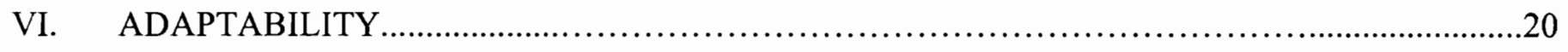

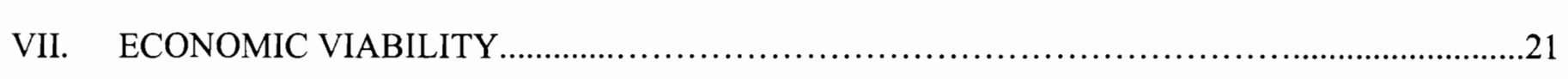

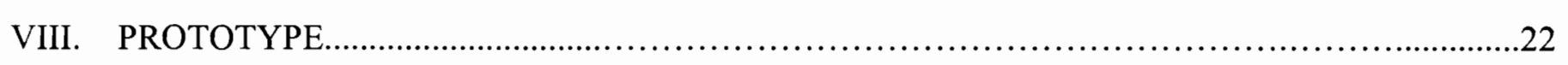

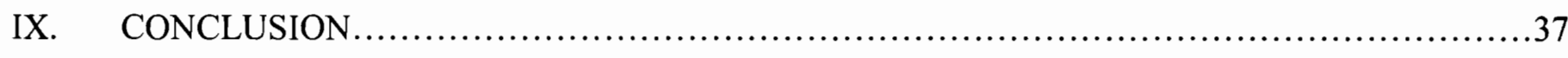

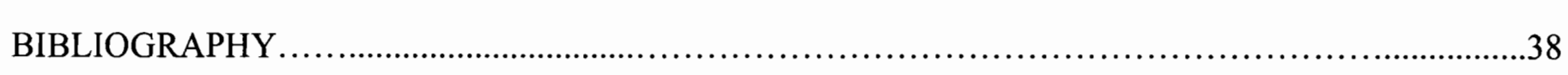

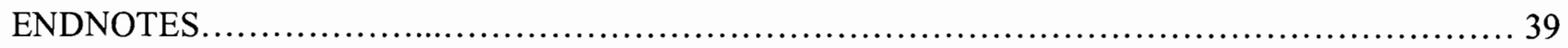


1. Site Overview

2. Site Overview.

3. Site Ariel. $\ldots . .2$

4. Site Photo - Low Density Example. ....2

5. Site Photo - Low Density Example.

6. Site Photo - Medium Density Example. $\ldots . .2$

7. Site Photo - Medium Density Example. .2

8. Site Photo - High Density Example..

9. Site Photo - High Density Example $\ldots . .2$

10. Site Photo - Miami River. .....2

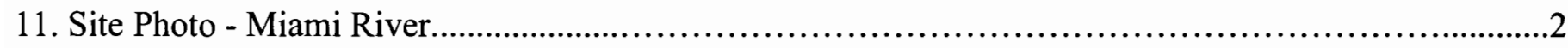

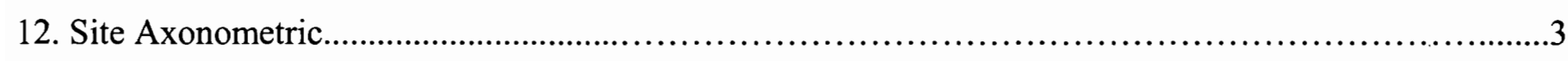

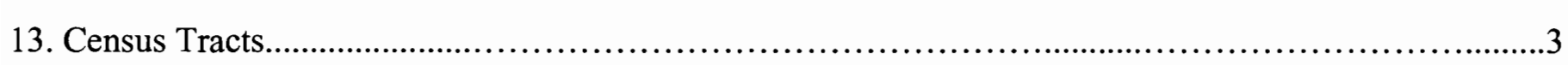

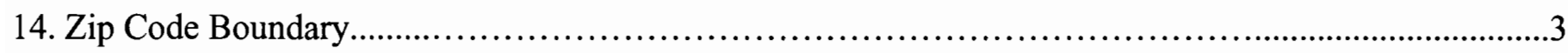

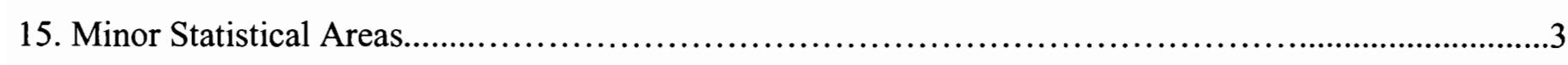

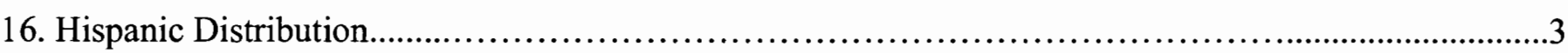

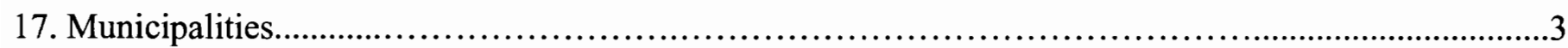

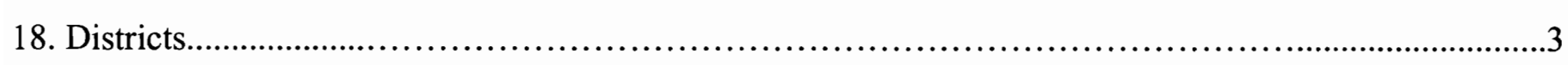

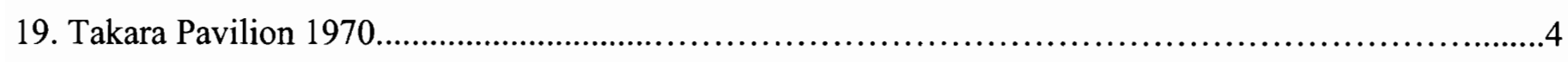

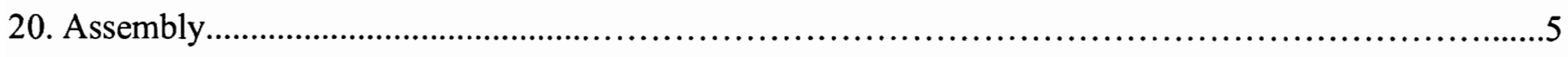

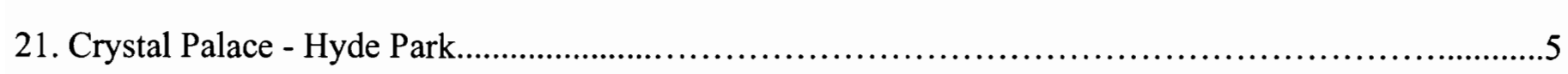

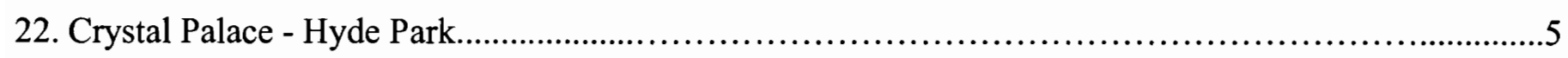

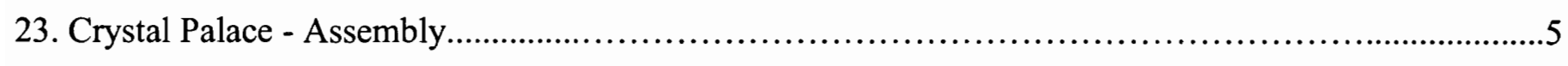

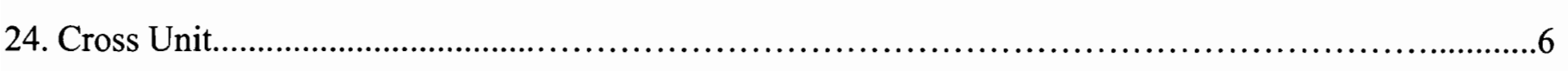


26. Assembly. ....7

27. Assembly.

28. Cross and Plates

29. Cross Family. ....8

30. Plate Family . .9

31. Material Axonometric $\ldots 10$

32. Material Axonometric . .11

33. Material Axonometric $\ldots 12$

34. Louver Balcony Large.. .....12

35. Louver Balcony Small.. ....12

36. Railing Balcony Large... $\ldots 12$

37. Railing Balcony Small.. $\ldots .12$

38. Storefront Balcony Large .....12

39. Storefront Balcony Small. $\ldots 12$

40. Walled Balcony Large. .12

41. Walled Balcony Small. ....12

42. Balcony Family. . .13

43. Full Assembly $\ldots . .14$

44. Assembly Detail. $\ldots .15$

45. Assembly Detail . .16

46. Assembly Detail. .....17

47. Unit Section Detail $\ldots 17$

48. Assembly Detail $\ldots .18$

49. Assembly Detail . .18

50. Assembly Detail. 
52. Assembly Detail

54. Example Rendering...

55. Building Rendering - close up.

56. Building Rendering

57. Site Plan.

58. Typical Plan A $\ldots .24$

59. Typical Plan B .25

60. Typical Double Unit. . .26

61. Single Unit A and B . .27

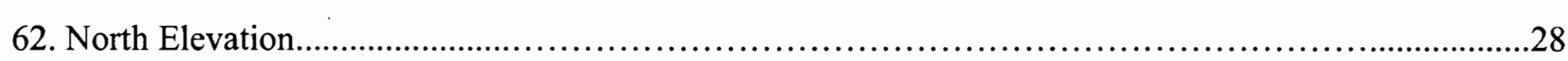

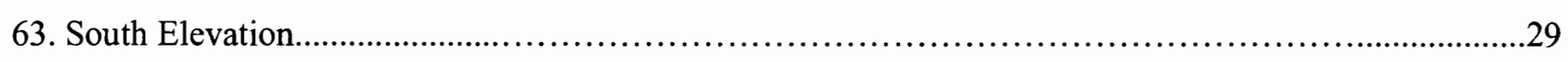

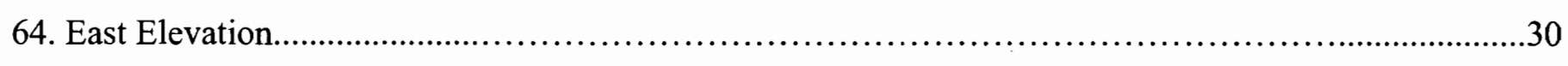

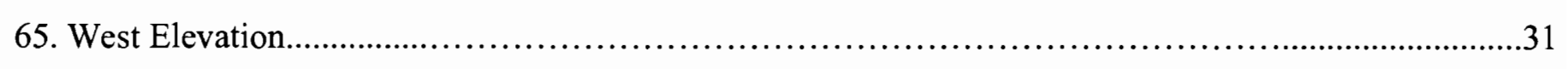

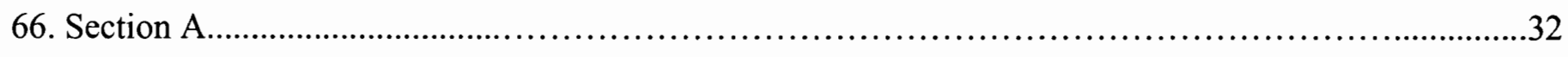

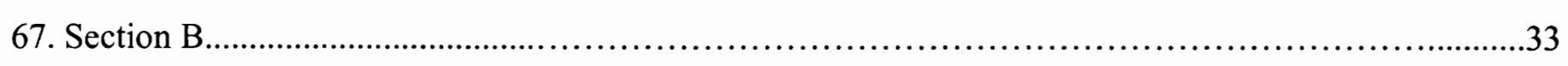

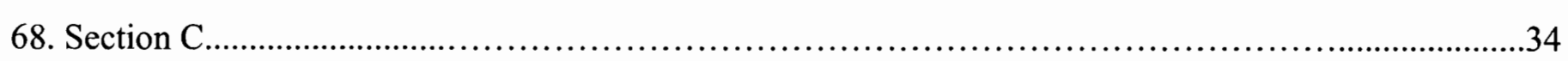

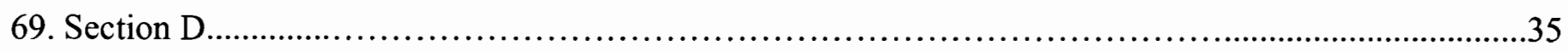

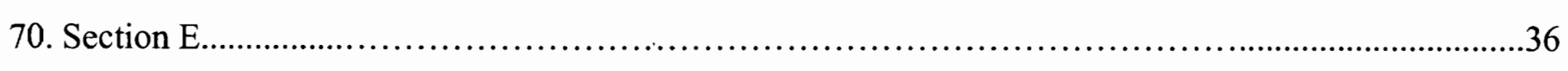

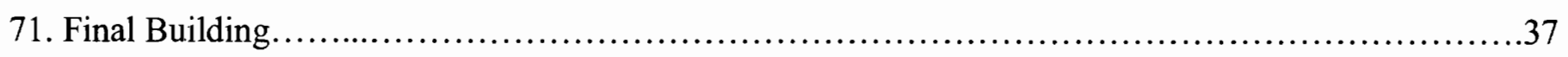




\section{INTRODUCTION}

Is there a way to improve today's urban construction techniques that would increase the efficiency and lower the cost of the entire process? This question allowed for an investigation of methods and concepts of construction that could be utilized to simplify the building procedure. Is it possible to design a construction system based around a single adaptable kit-of-parts system without severely limiting the building's ability to merge into the current urban fabric? This thesis is sited in downtown Miami. It is an urban residential structure built with a handful of structural units. With close attention to formal composition, process, adaptability, and economic viability, the design will embrace its surrounding context and provide an effective urban element within downtown Miami.

With the reemergence of Miami's downtown, architects increasingly focus on new urban conditions such as increased density and building within a historic context (See Figures 1-2). The solutions that have been presented to date utilize the current construction system of building that can be costly and time consuming.

A kit-of-parts building system and streamlined construction process could create more cost-effective space and create savings which could be passed onto the consumer. The revitalization of the city could reduce all kinds of problems from reducing morning traffic to slowing the effects of urban sprawl and providing more affordable housing.

This project was to design a new construction system which when introduced into Miami's urban fabric, could both increase density quickly and effectively. This new system is done through a design of a residential building situated in an area of the city currently under reconstruction.
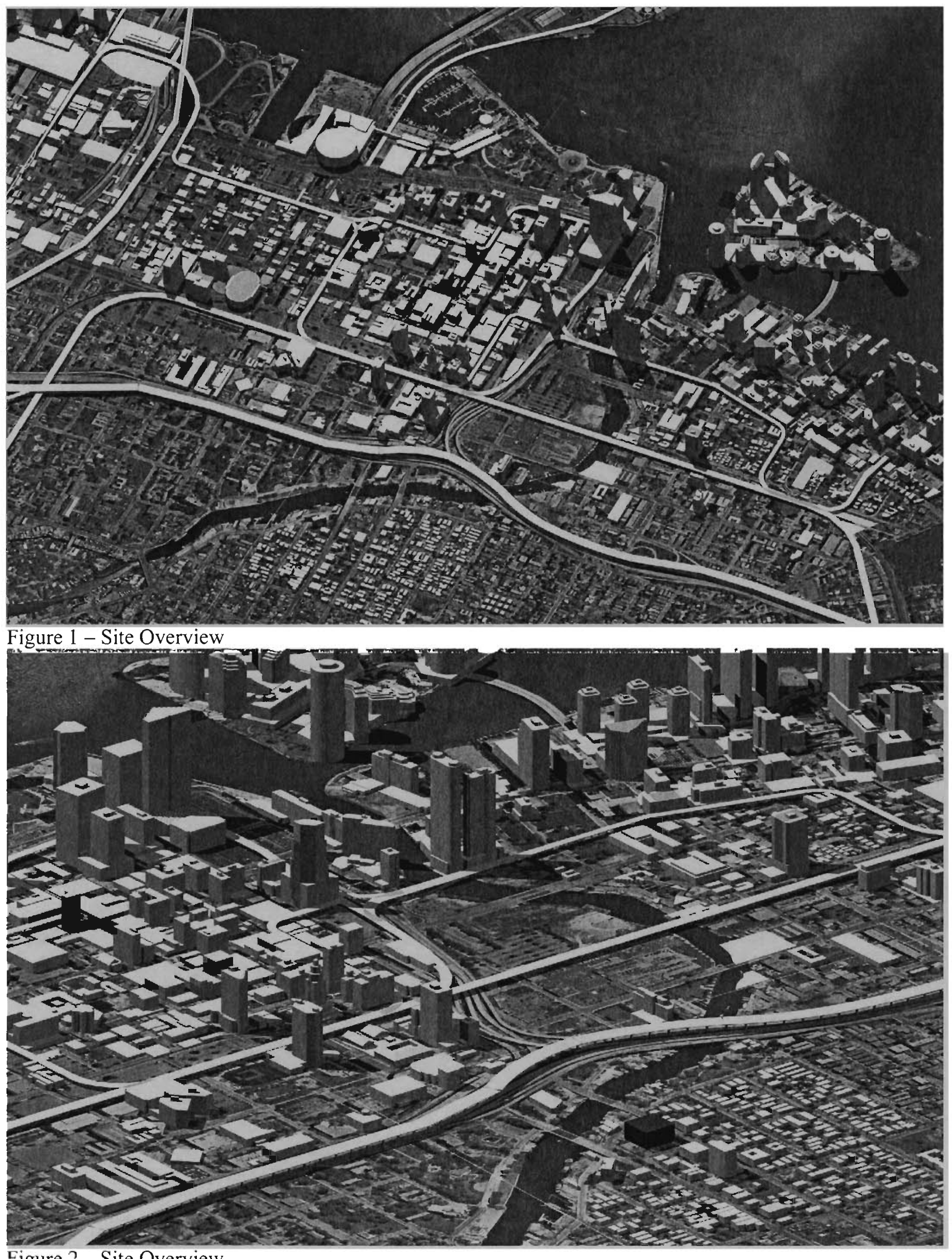

Figure 2 - Site Overview 


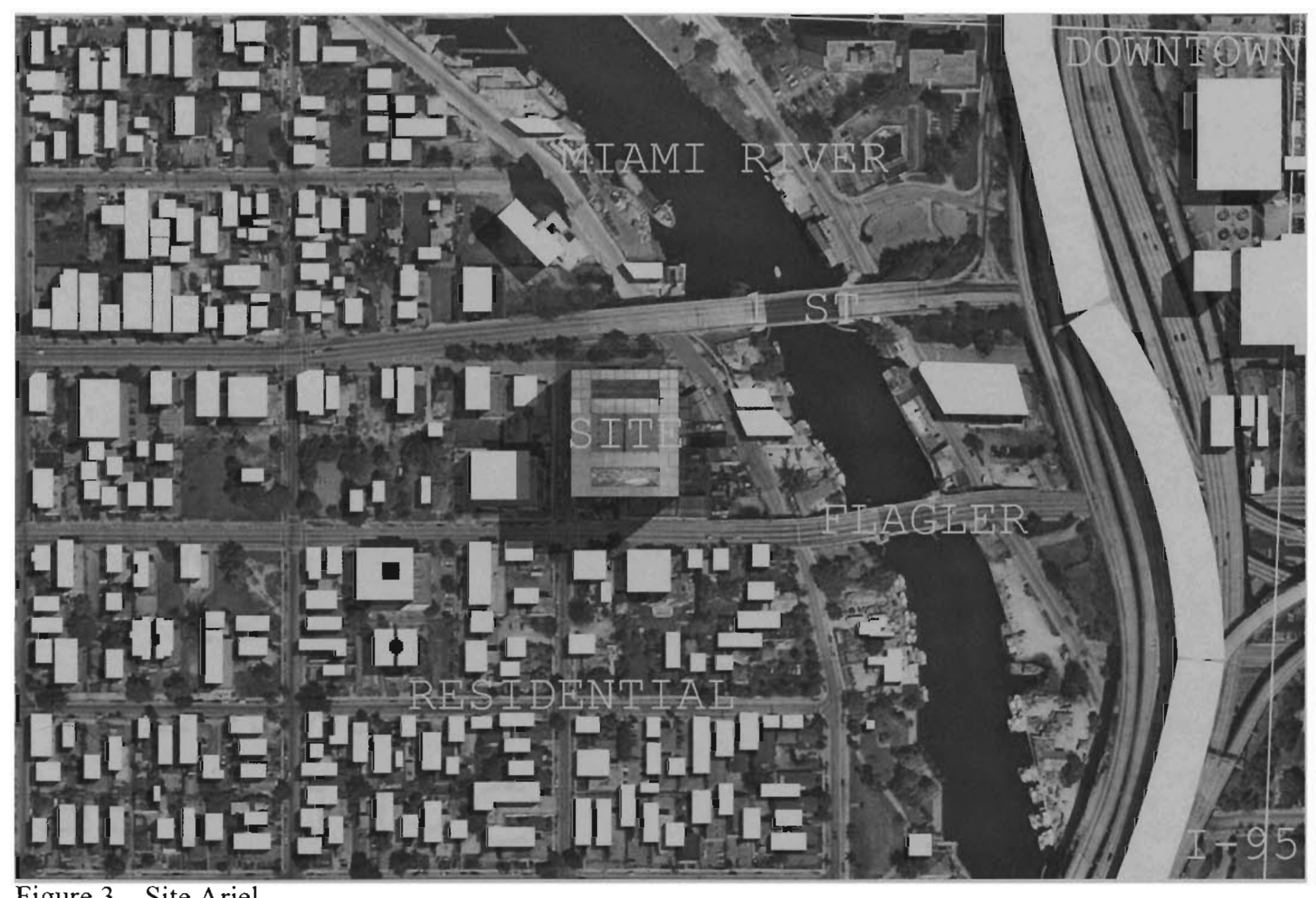

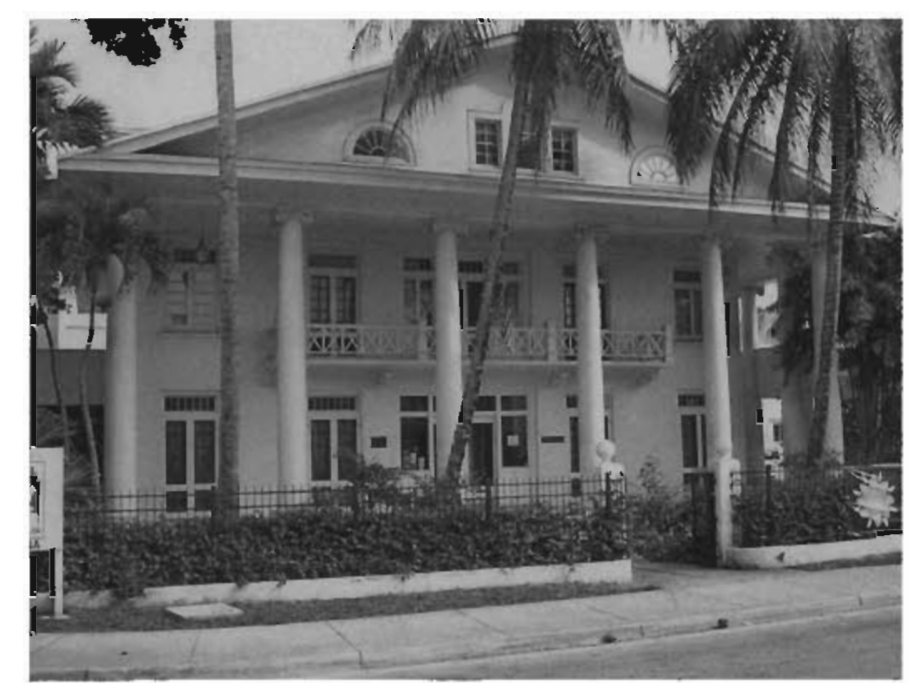

Figure 4 - Site Photo -

Low Density Example

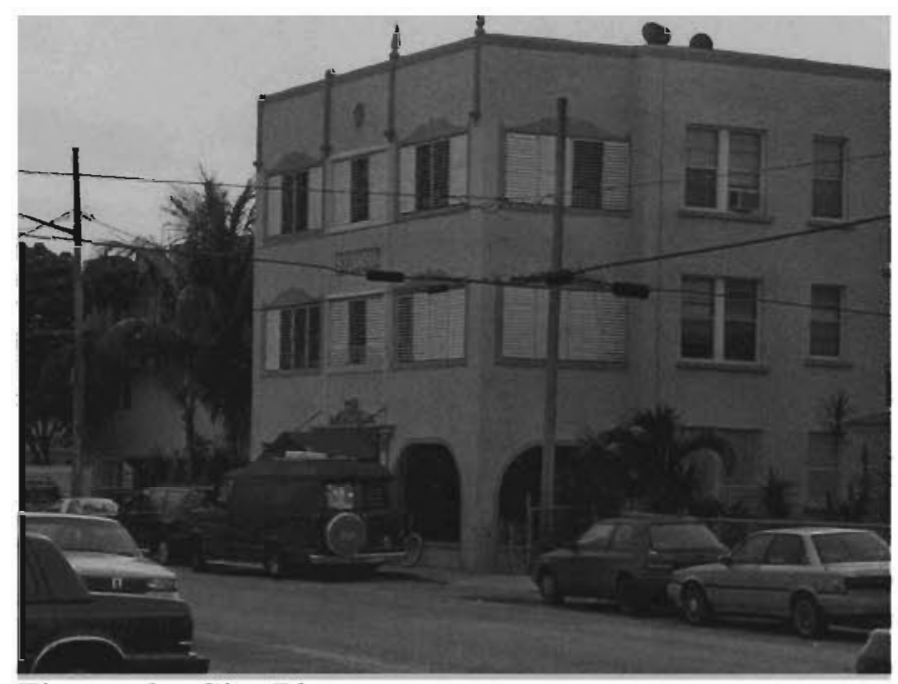

Figure 6 - Site Photo -

Medium Density Example

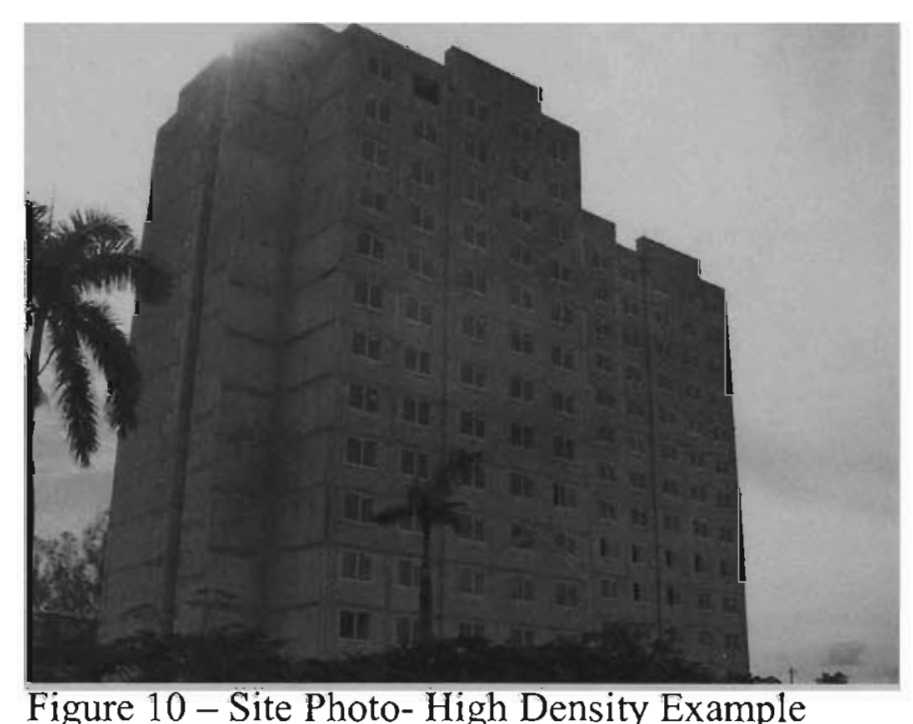

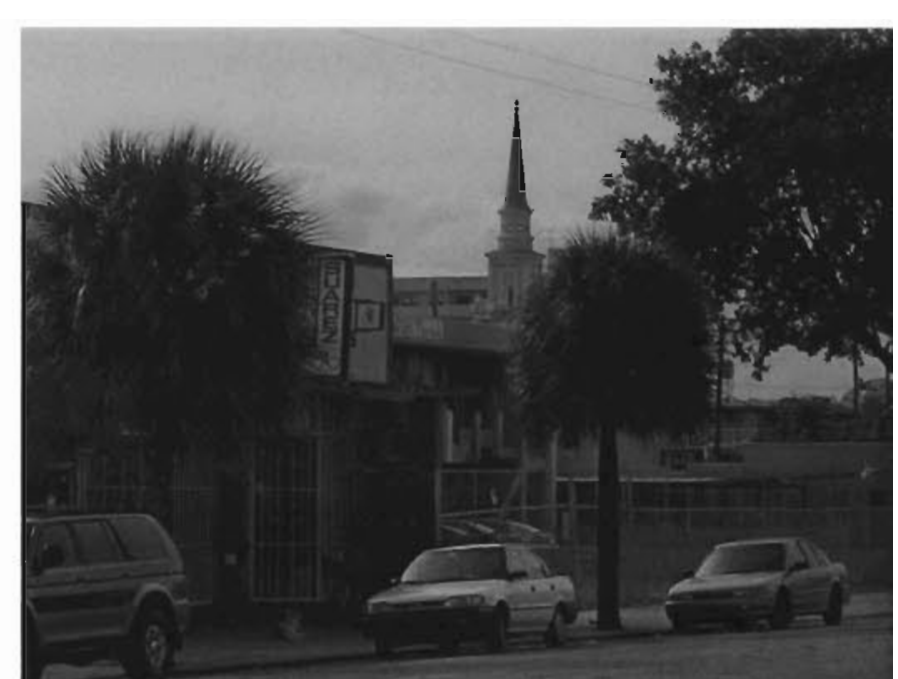

Figure 5 - Site Photo -

Low Density Example

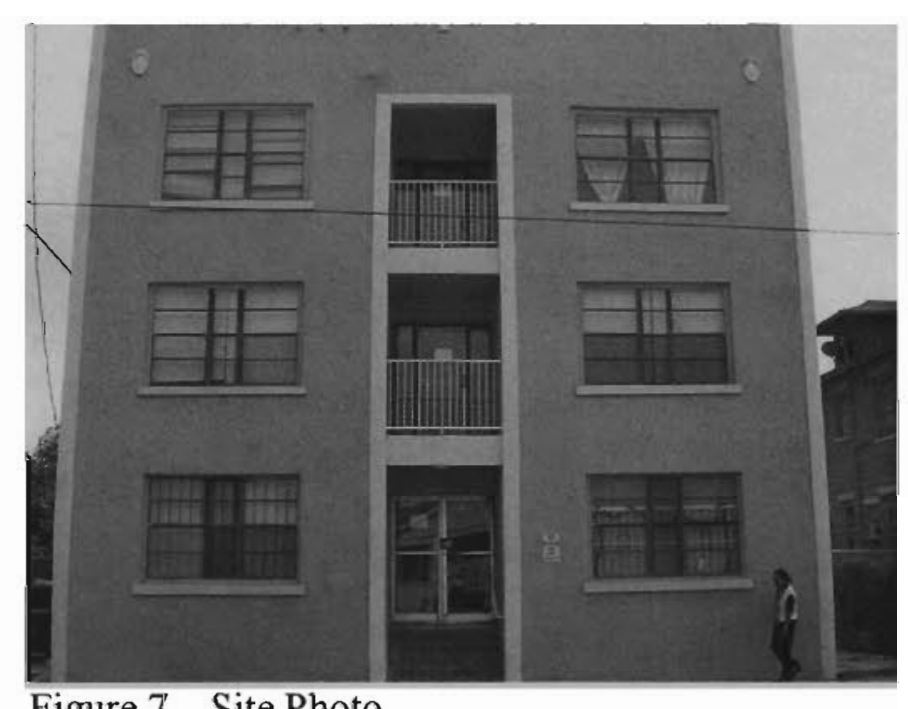

Figure 7 - Site Photo -

Medium Density Example

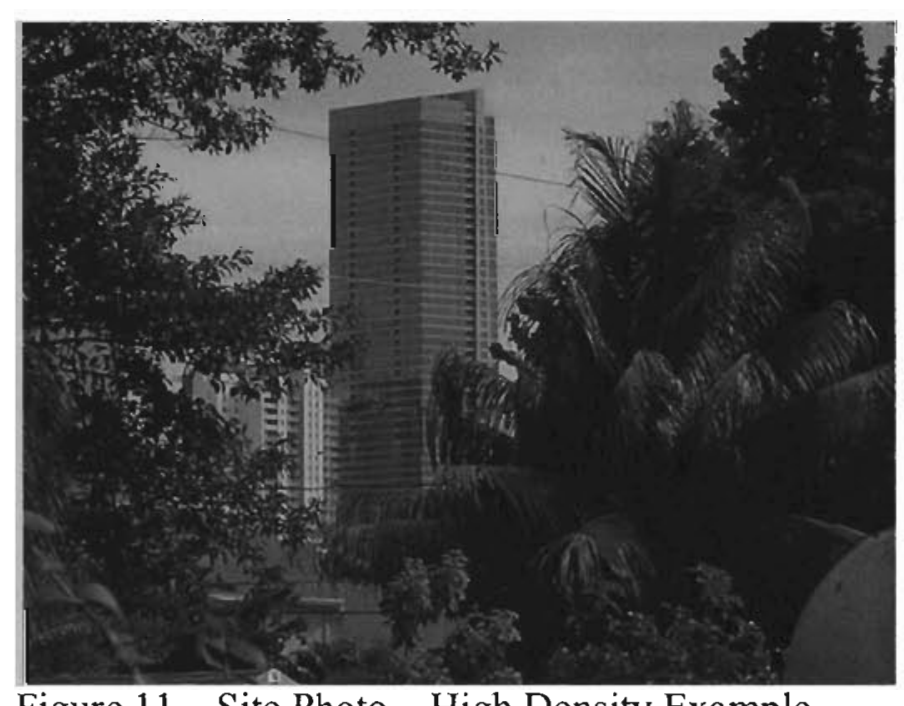

Figure 11 - Site Photo - High Density Example 


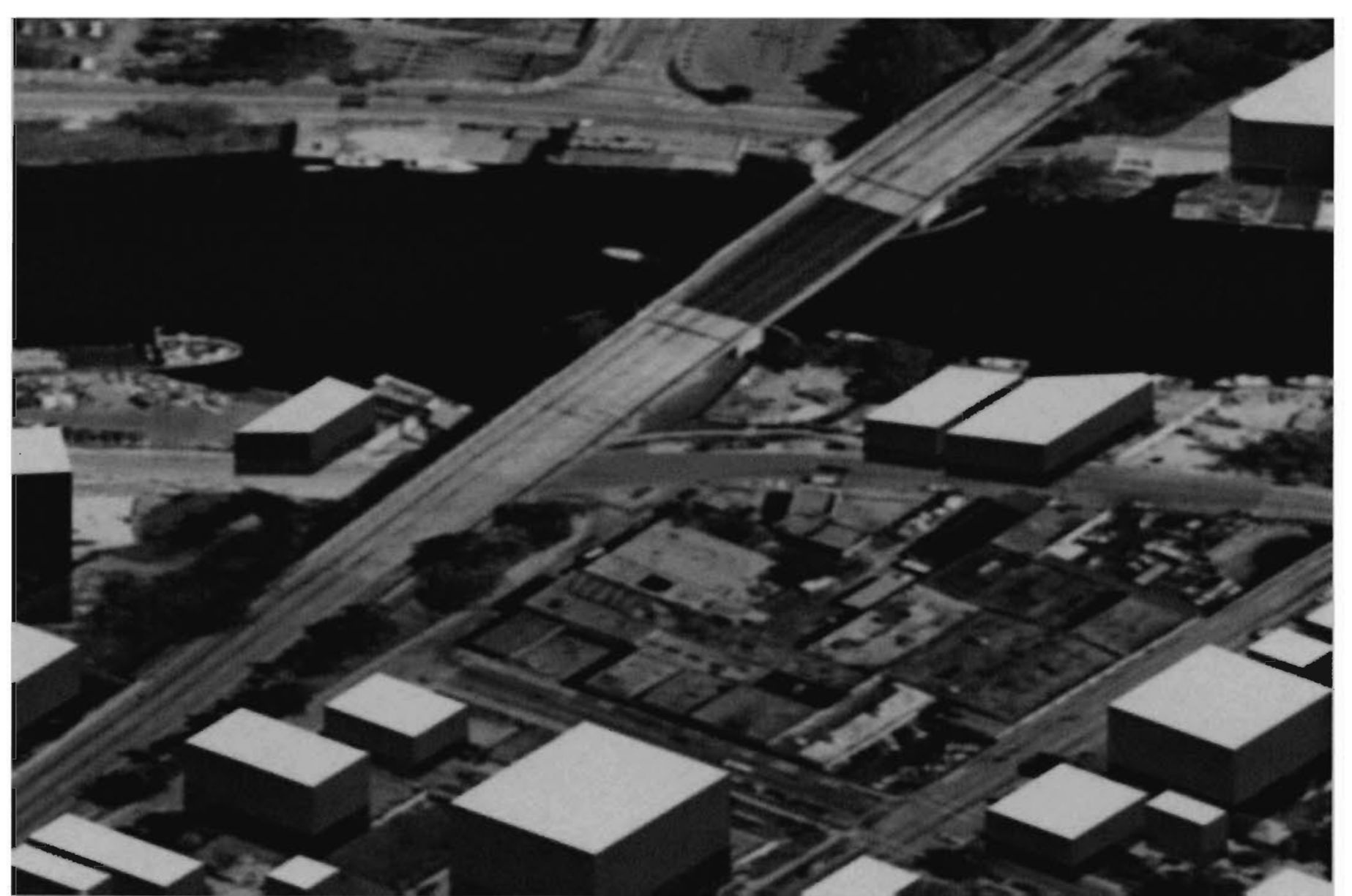

Figure 12 - Site Axonometric

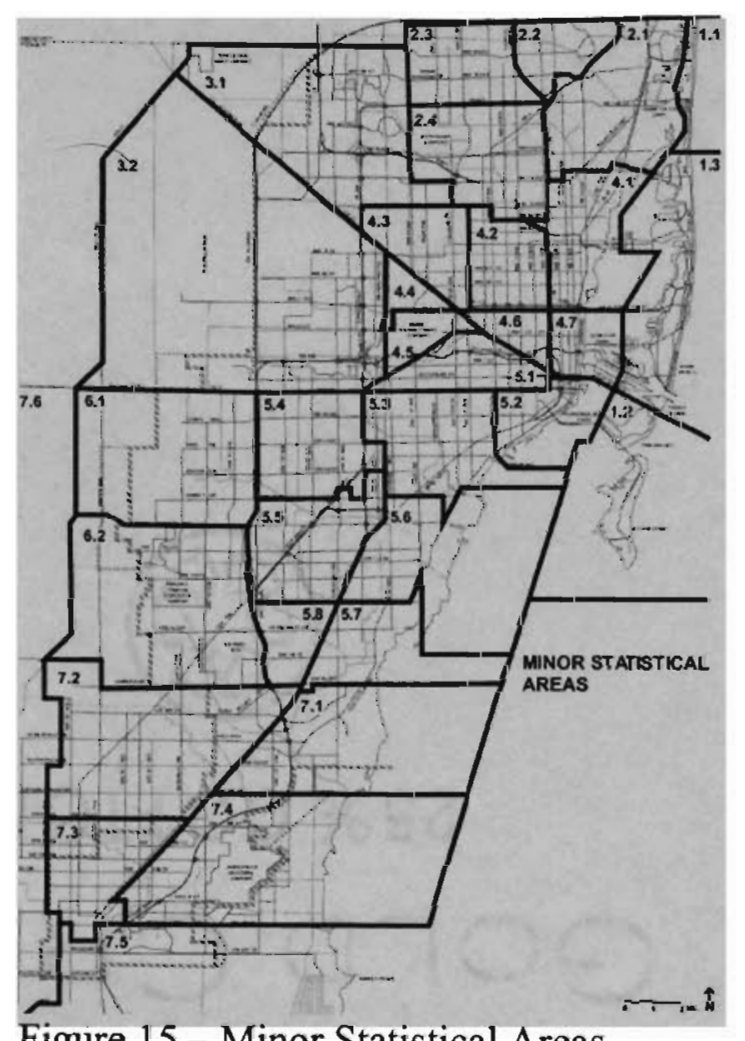

Figure 15-Minor Statistical Areas

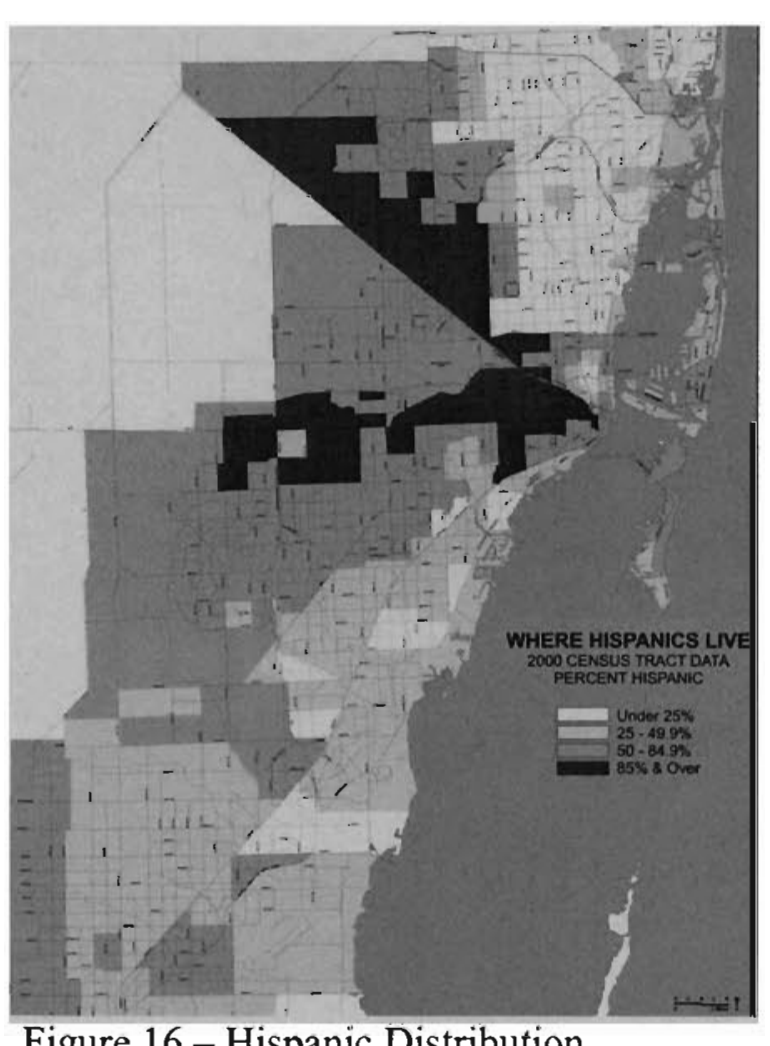

Figure 16 - Hispanic Distribution

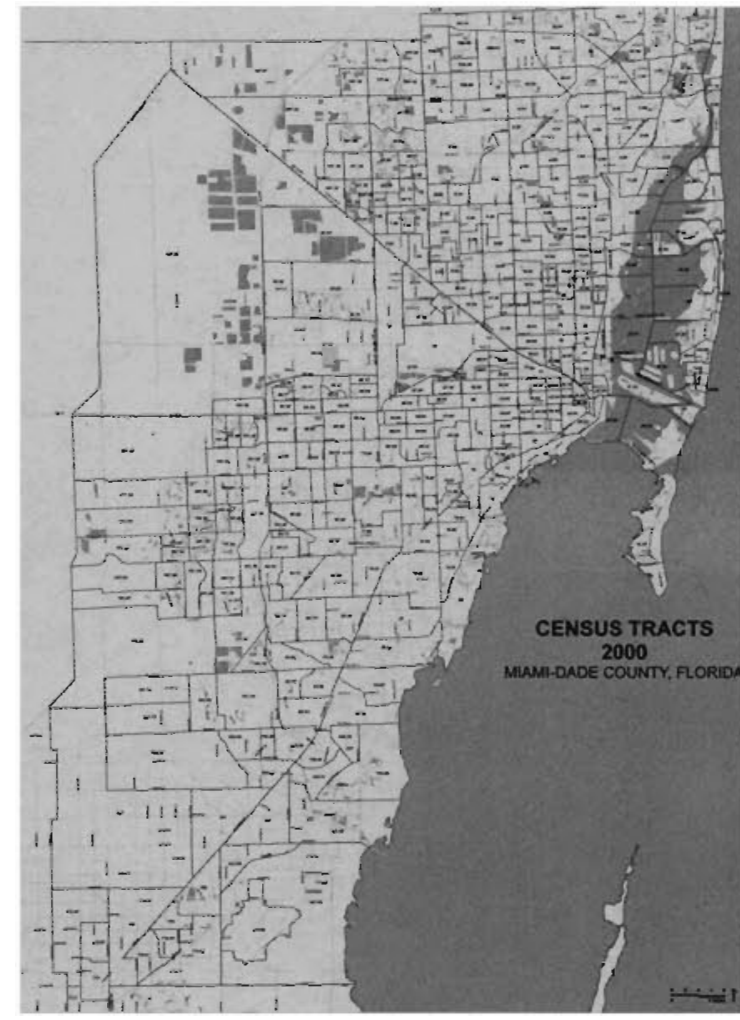

Figure - 13 Census Tracts

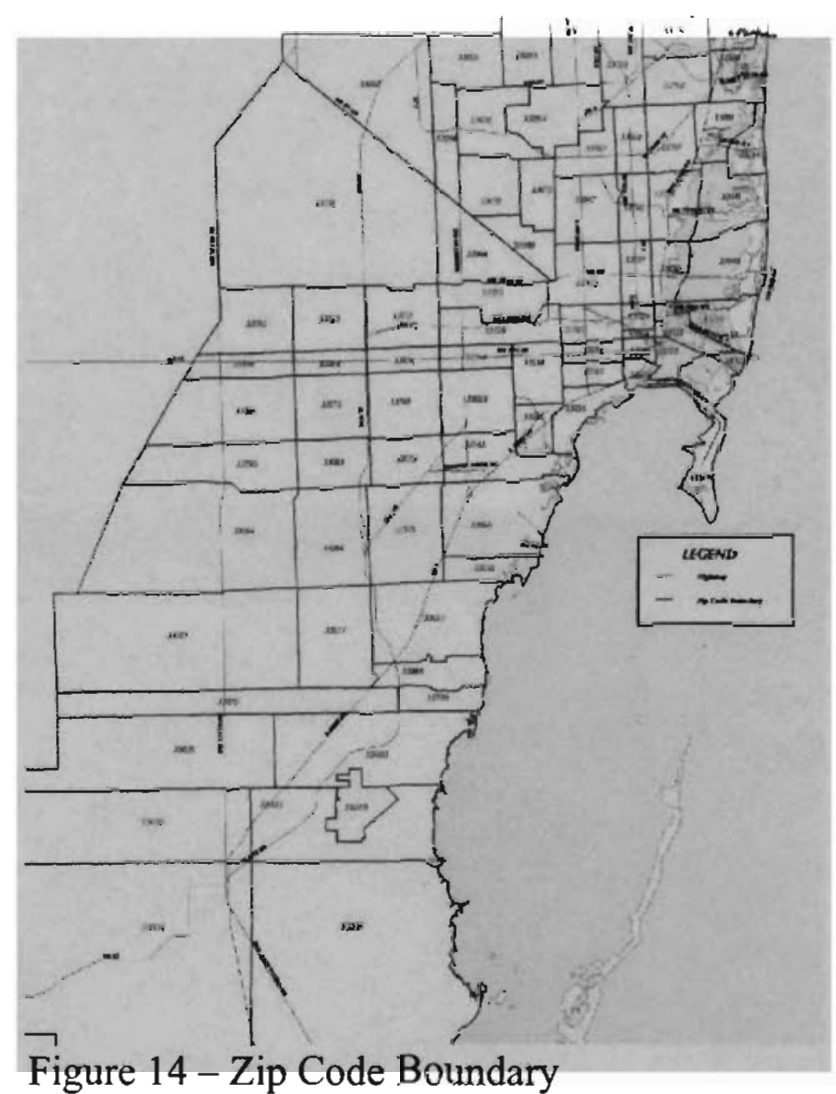

Figure 14 - Zip Code Boundary

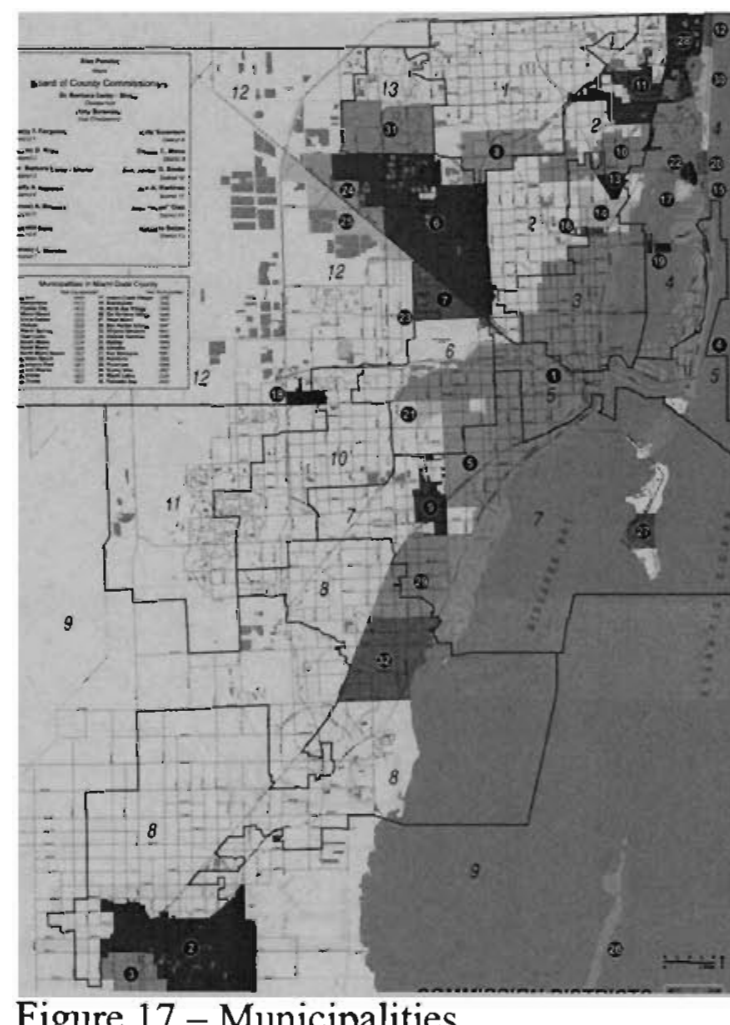

Figure 17 - Municipalities

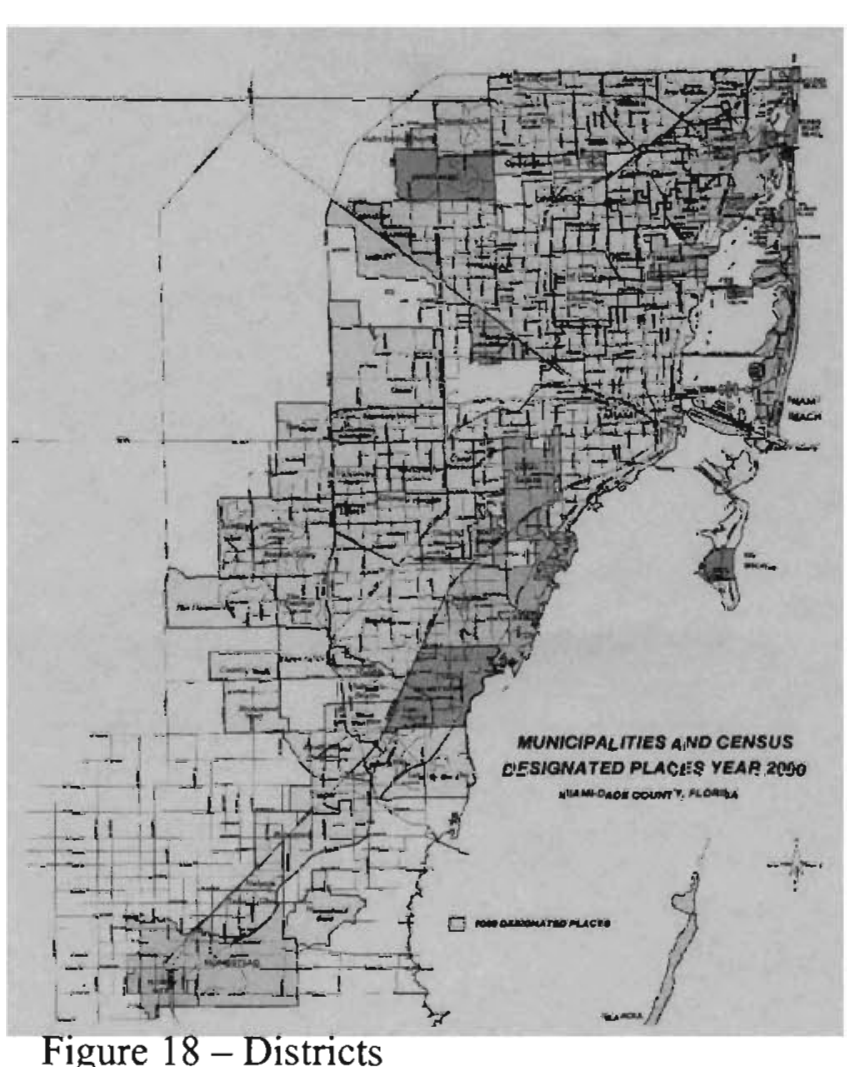

Figure 18 - Districts 
construction system (See Figure 19). Robin Boyd explained the system, "The structural system is based on a single pre-fabricated framing unit which is repeated some 200 times. Each unit is made up of 12 blunt rightangle bends of steel pipe (10 cm diameter) welded to make six arms, each consisting of four pipes grouped in a square, thus forming overall a $3-d$, six-pointed cross measuring 3.3 meters in each of the three

dimensions... The end of each arm is welded to a flat circular disc, like a hand holed for bolts. When several of these units are bolted together at the discs, they make up a space frame of repetitive cubes... Floors are of pre-cast concrete slabs dropped into the steel frame. The whole system looks as easy and as full of fun as a toy construction kit." He goes on to say, "Joining was accomplished by the use of high tension bolts and assembly was extremely easy to complete, only a few days were required."1

The main form of the project's structural unit was derived from the figure present in the pavilion. Rather than steel, concrete was used because it can be considered a finished material and the replication process is easier when considering the degree of flexibility required. Finally, a key observation that Mr. Boyd made was the ease and speed of the construction process, which are definite goals of the design.

The first kit-of-parts building, The Crystal Palace, built in London in 1851, exemplifies the speed and efficiency by which these types of building's can be assembled (See Figure 20-23). That year England was scheduled to host an exhibition of the most modern technologies and they needed a large space to hold the event. They employed Joseph Paxton, a botanist with experience in building greenhouses, who assembled the Crystal Palace in ten days. "Built out of prefabricated and wrought-iron elements and based on a fourfoot module, this 1,848-foot-long ferro-vitreous construction was erected to the designs of Joseph Paxton and Charles Fox of Fox, Henderson \& Co. Its interior volume was organized into galleries that were alternately 24 feet and 48 feet wide. The roof of these galleries stepped up by 20 feet every 72 feet and culminated in a central nave 72 feet wide. The 'ridge and furrow' roof glazing system specially devised for the occasion required 49-inch glass sheets capable of spanning between furrows 8 feet apart, with three ridges occurring every 24 feet." ${ }^{2}$ It was located in Hyde Park and housed oven a million square feet of

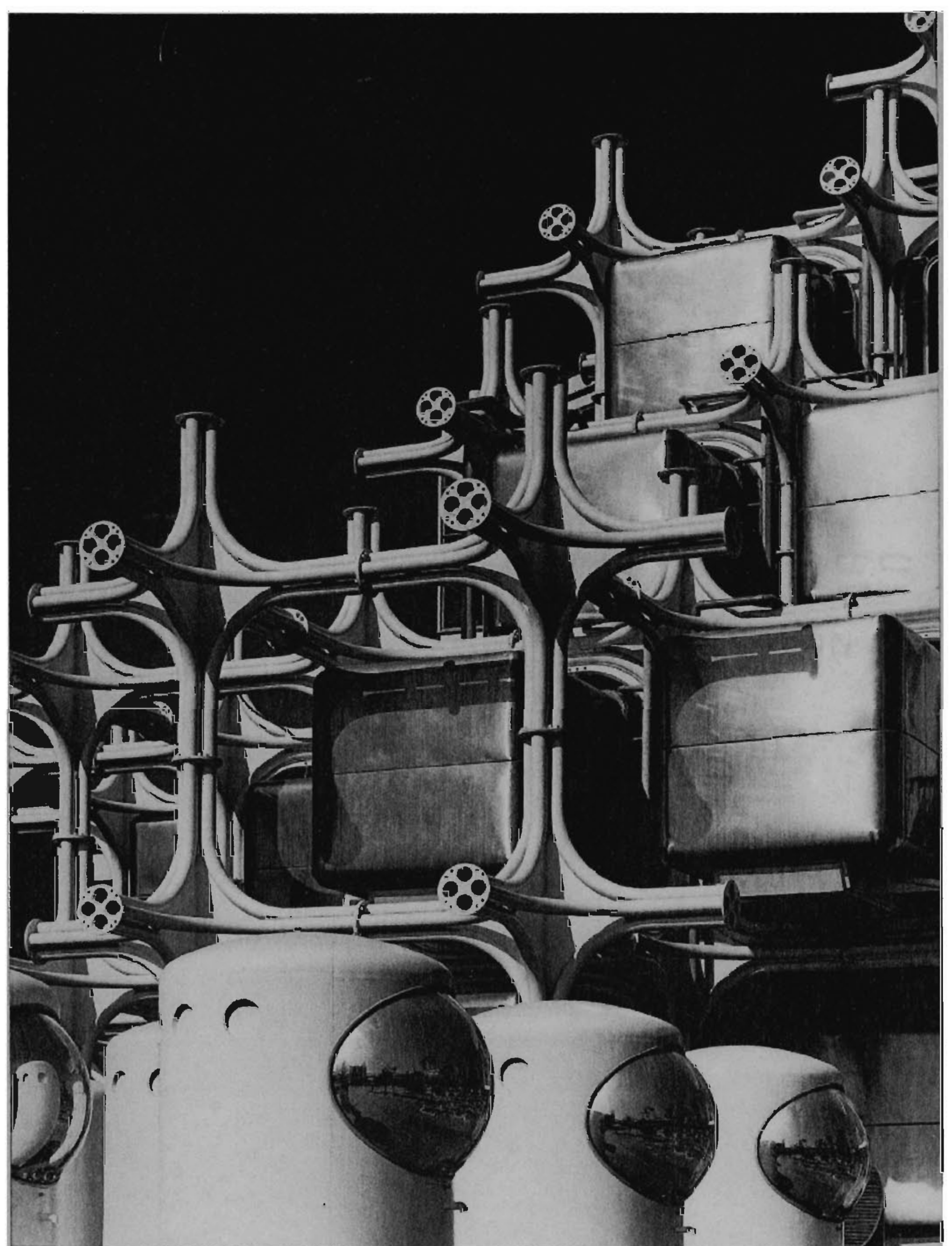

Figure 19 - Takara Pavilion 1970 
exhibition space. So successful was the Crystal Palace that when no longer needed it was disassembled and moved to another location. The idea that an entire building could be moved by simply disassembling it and reassembling it somewhere else motivates this thesis. The lesson from this masterpiece is the importance of construction organized where all the pieces arrive together to form the building with economy and speed.

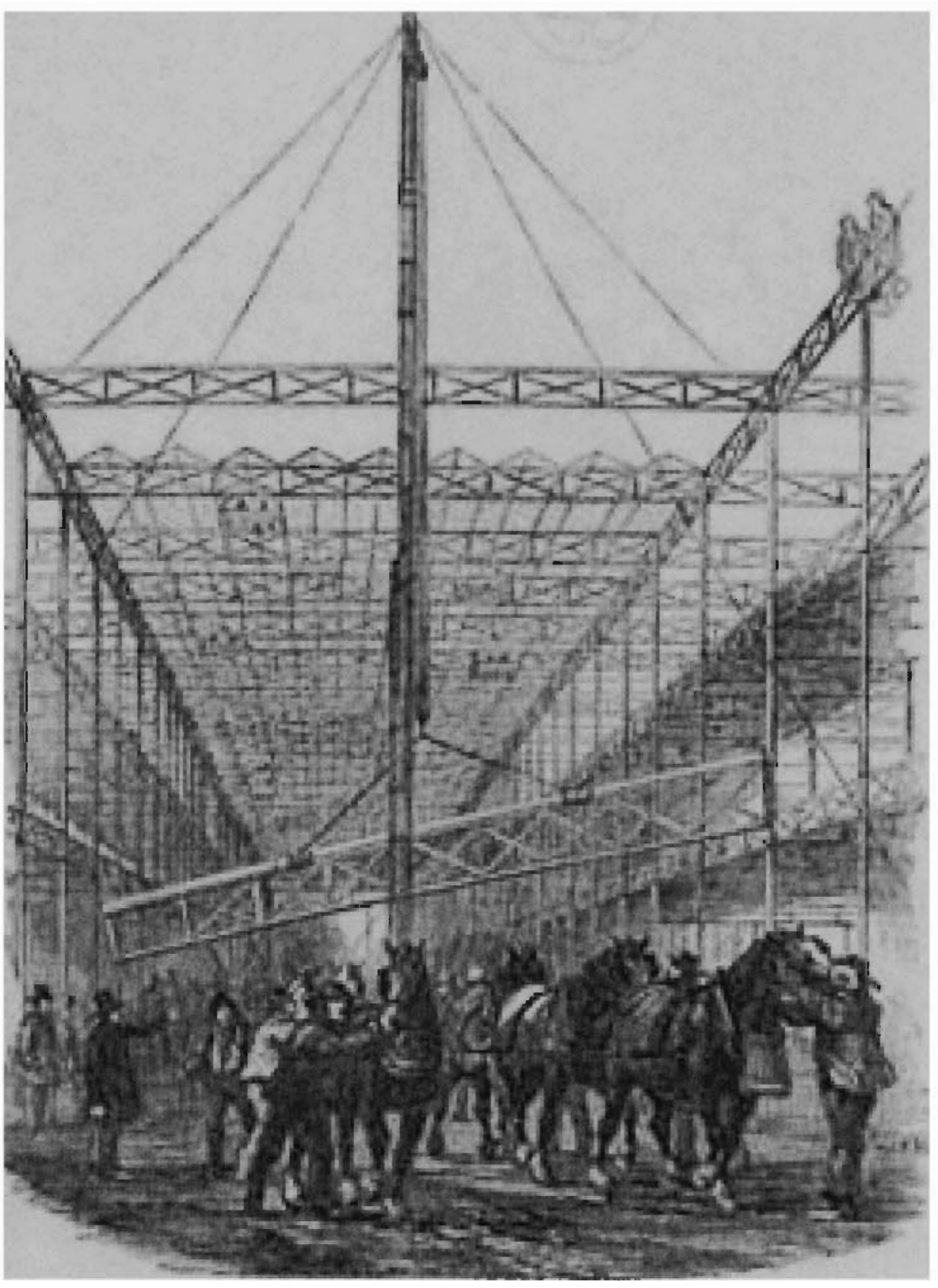

Figure $20-$ Assembly

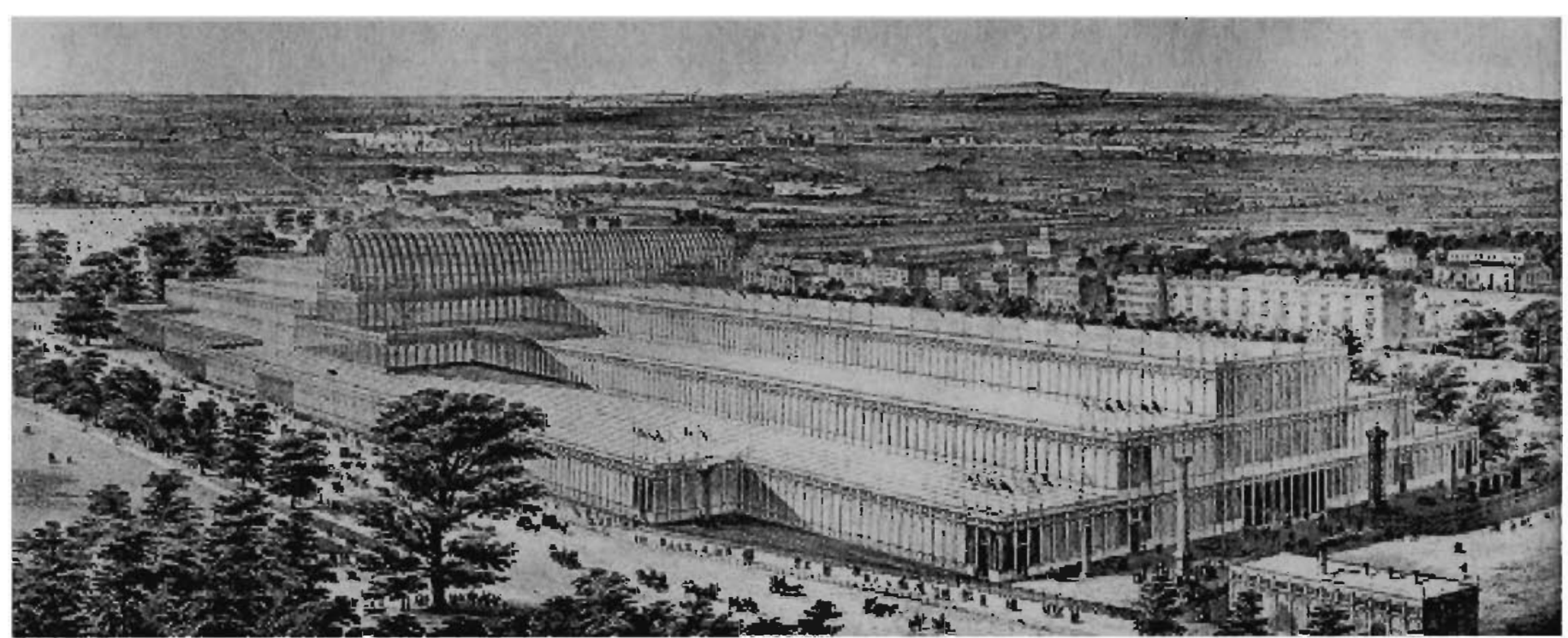

Figure 21 - Crystal Palace - Hyde Park
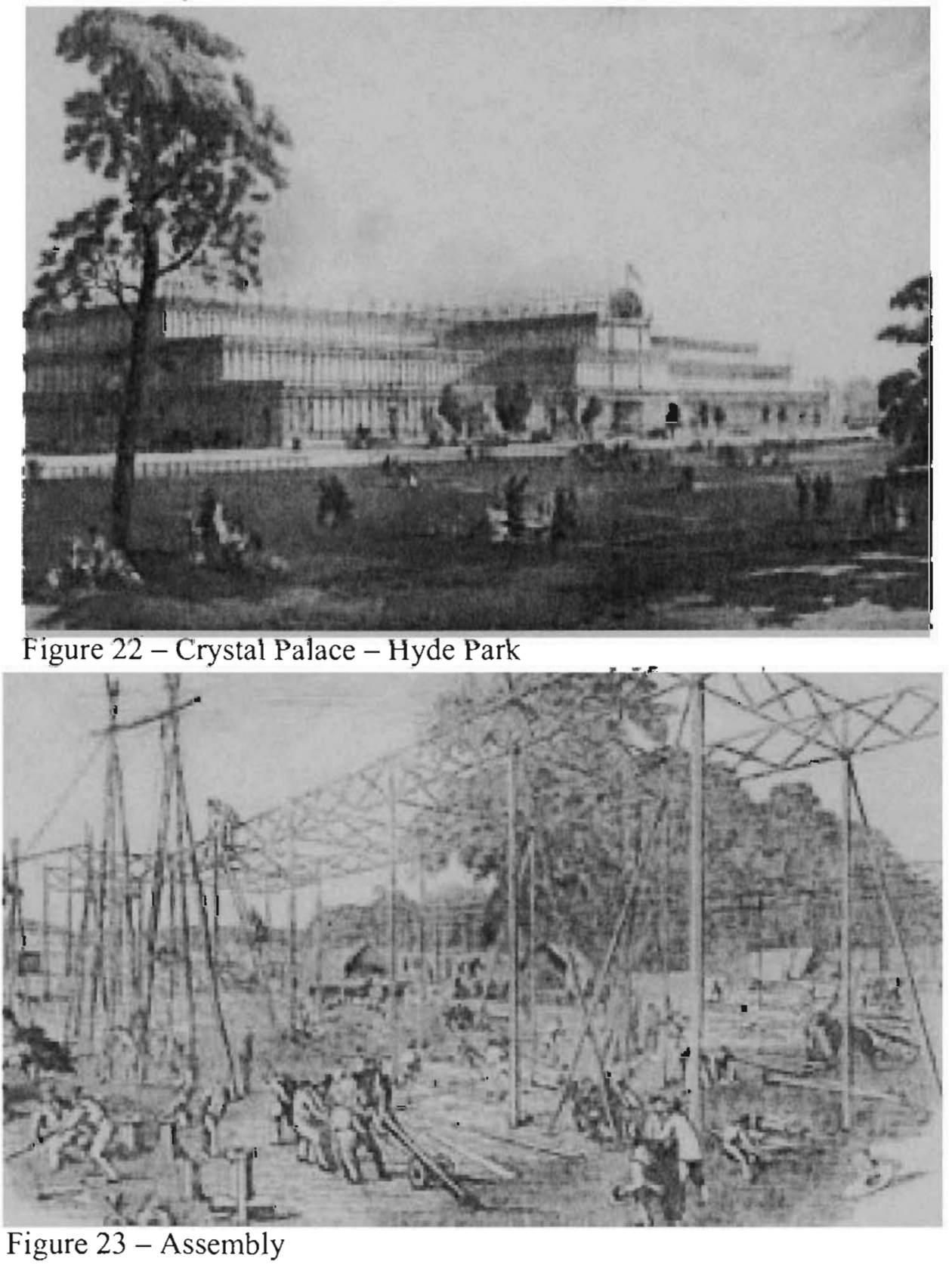


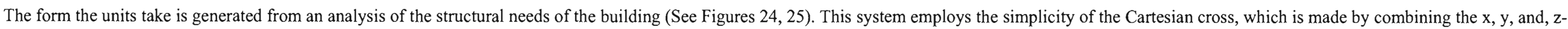

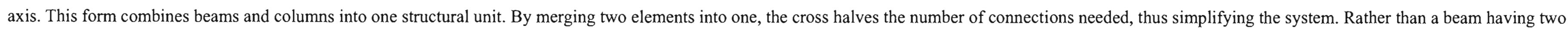

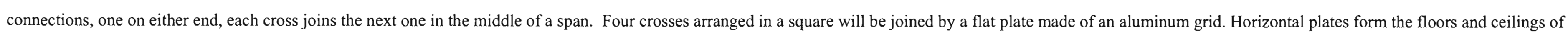
the building while the vertical plates will function as demising walls as well as elements that resist shear and other lateral forces (See Figures 26-28).
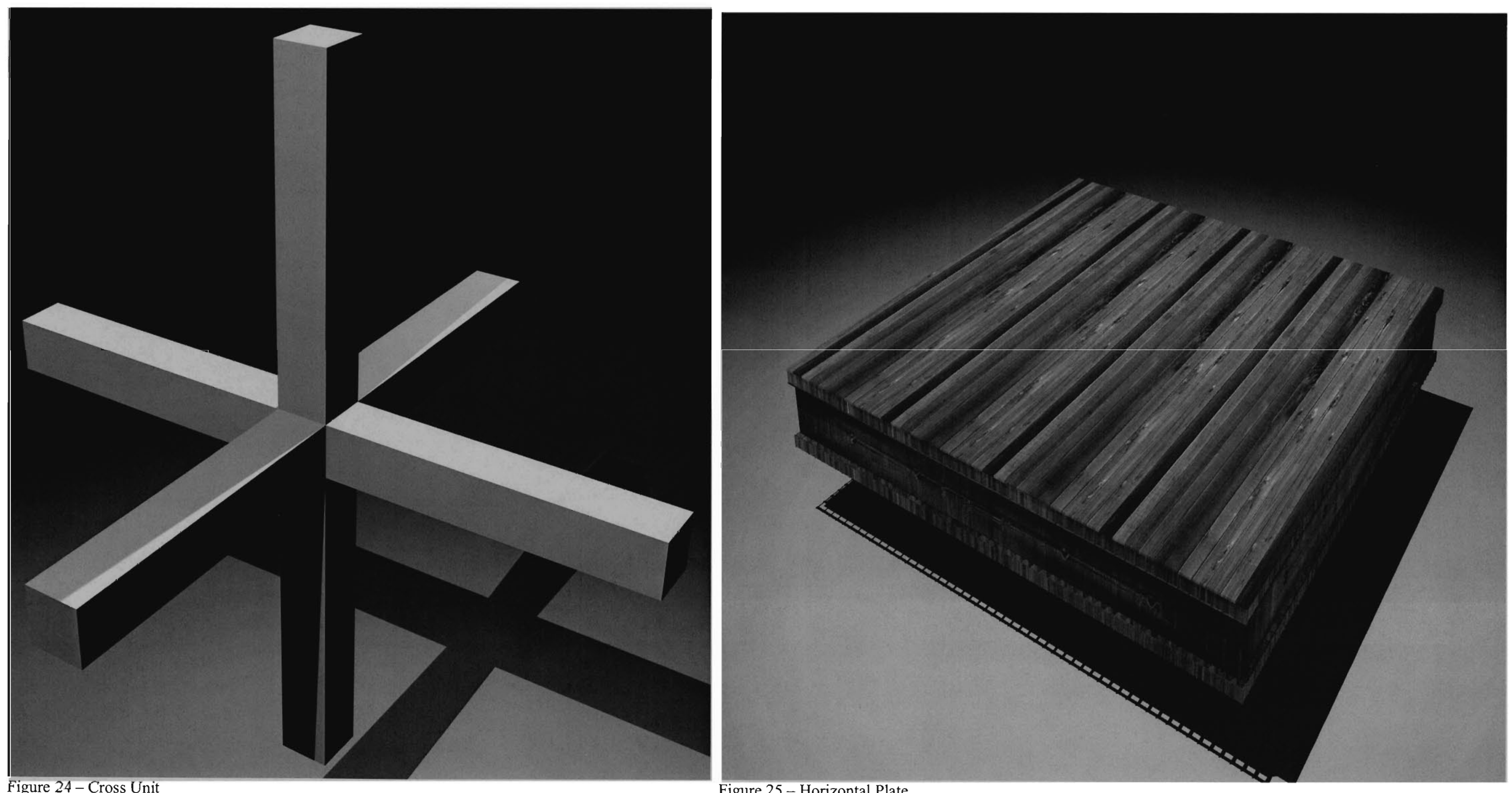


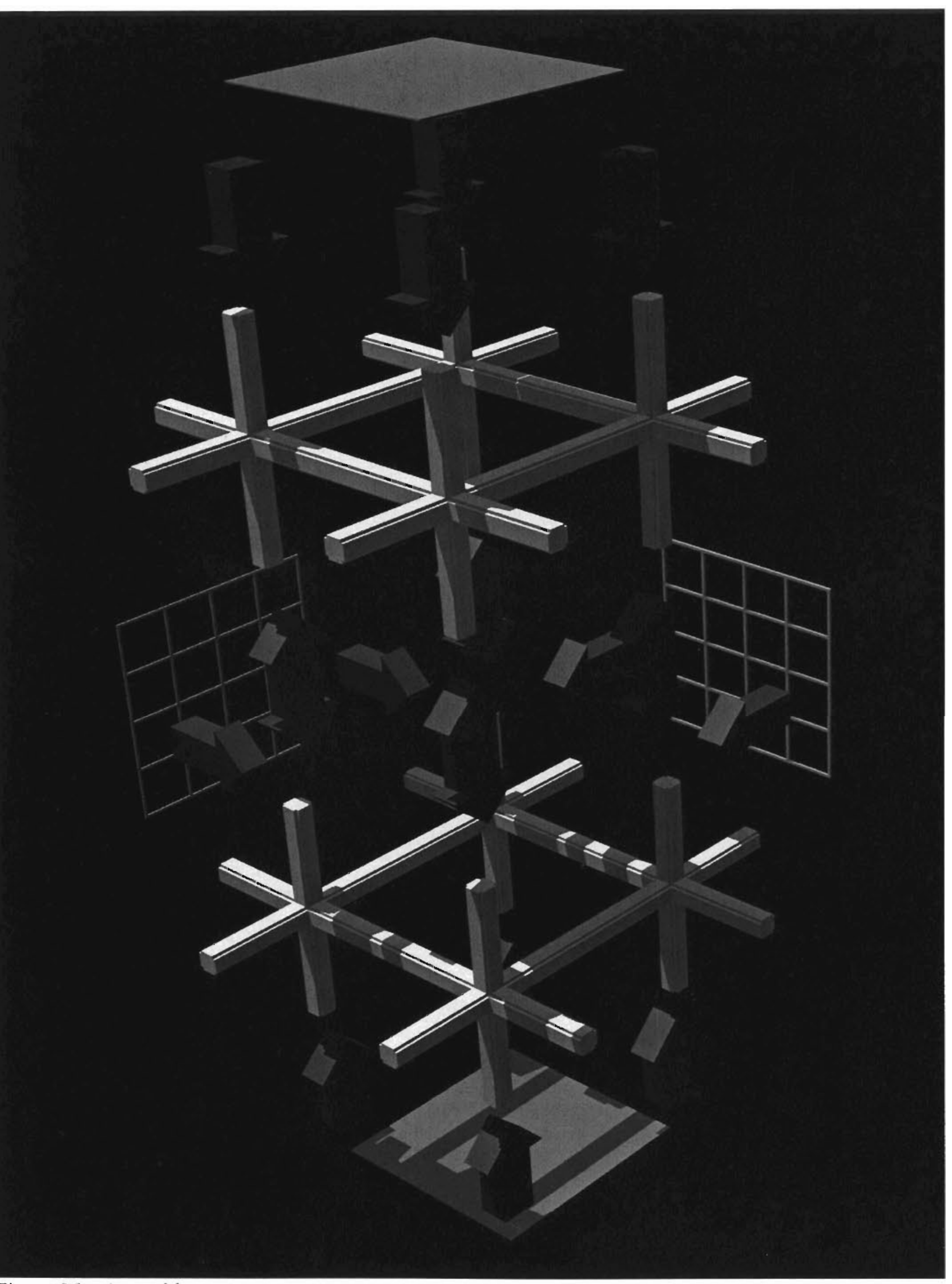

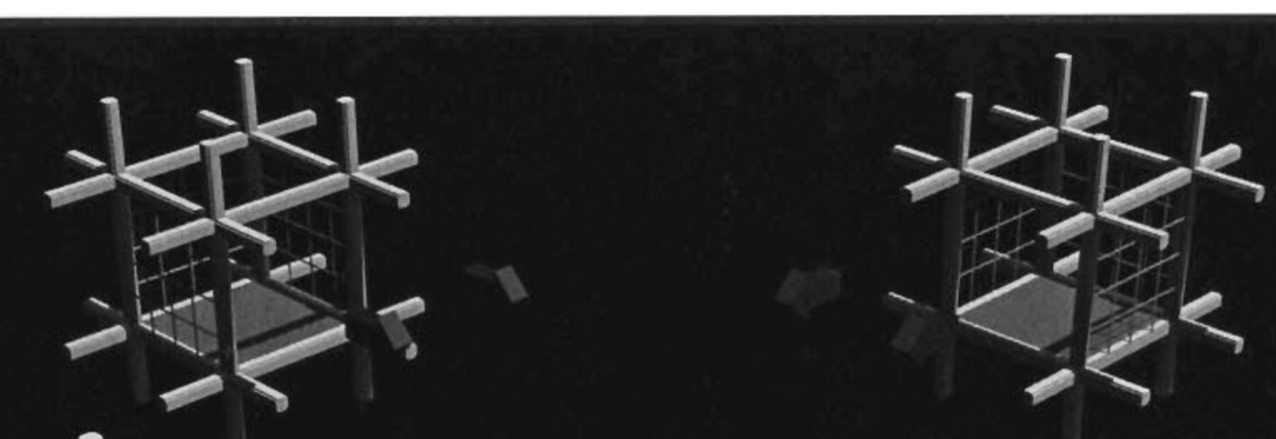
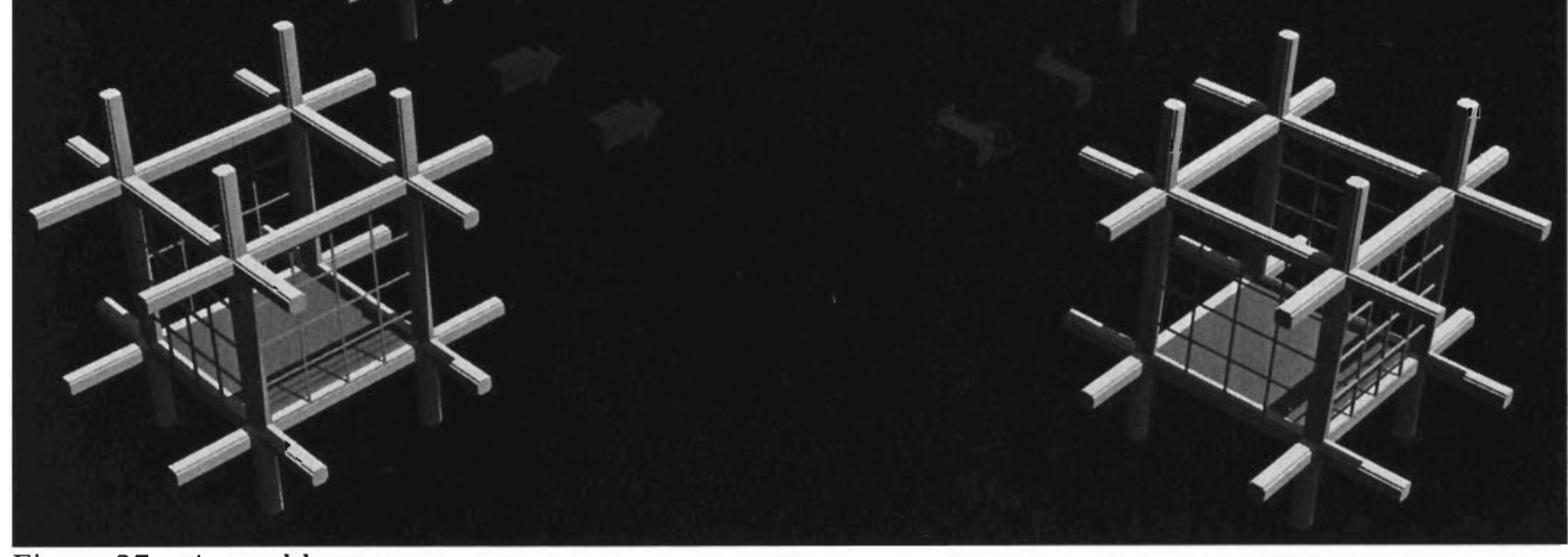

Figure 27 - Assembly

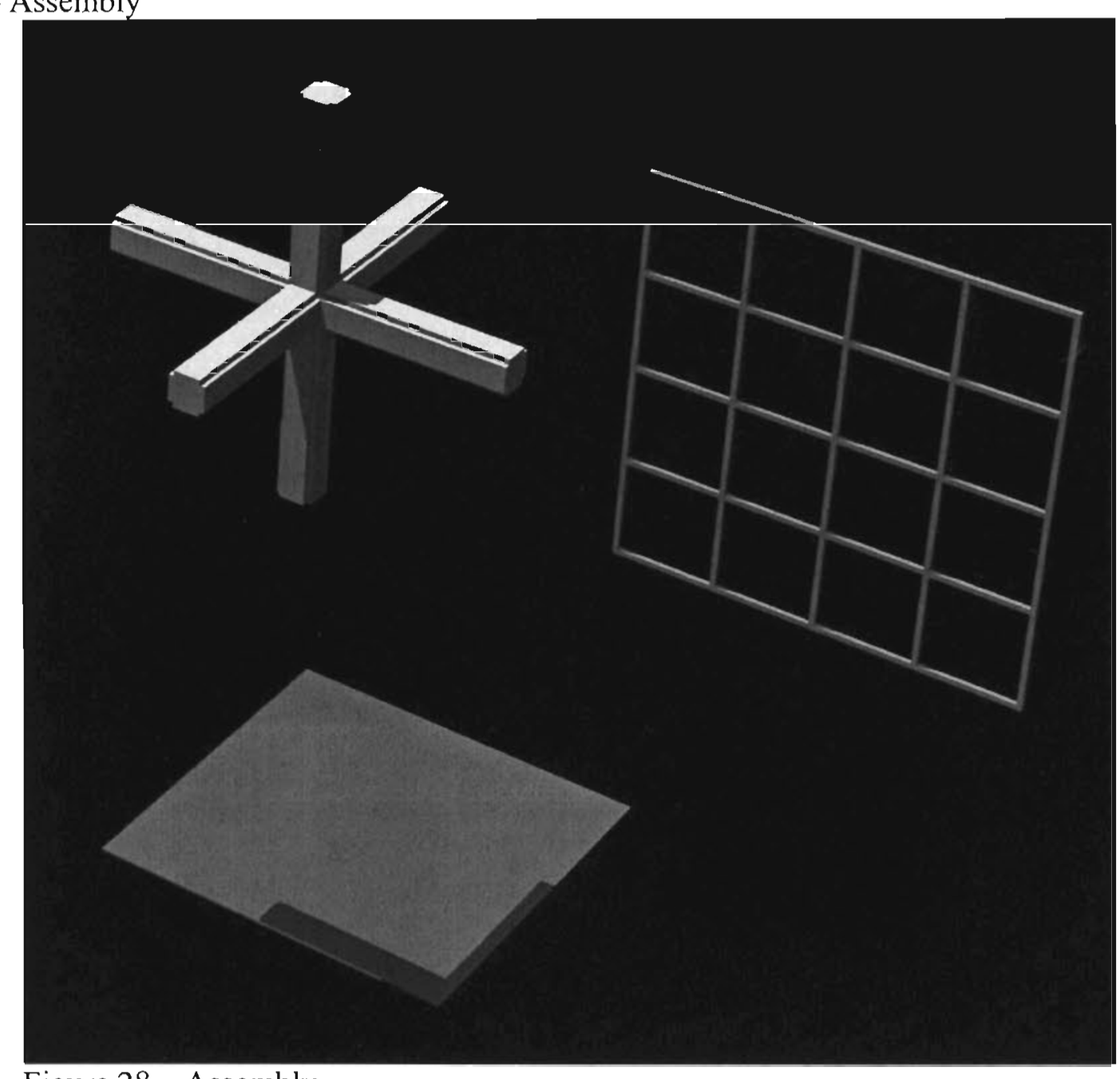

Figure 28 - Assembly 


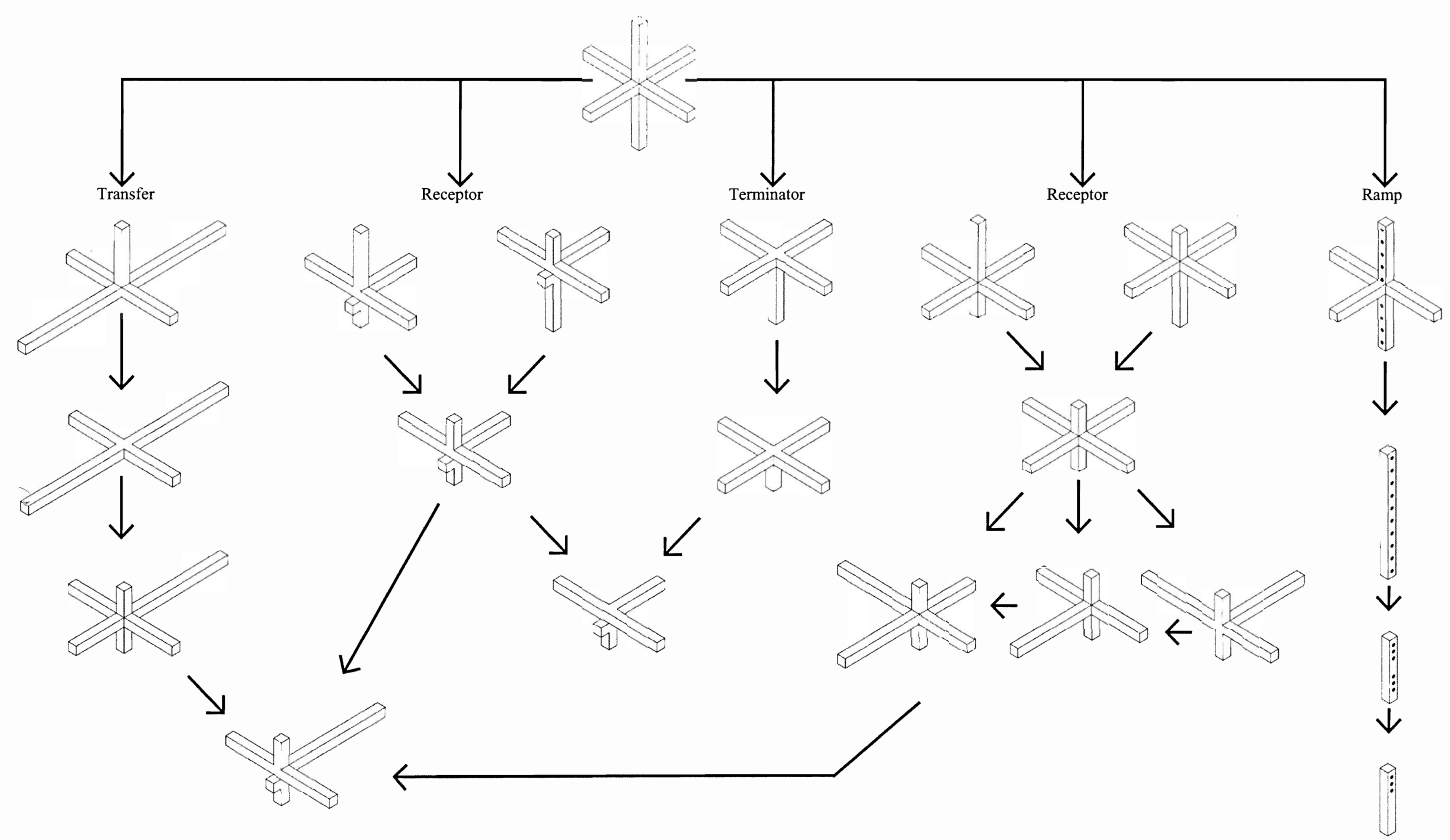



greater flexibility in the size and shape of the spaces that are formed within the building.

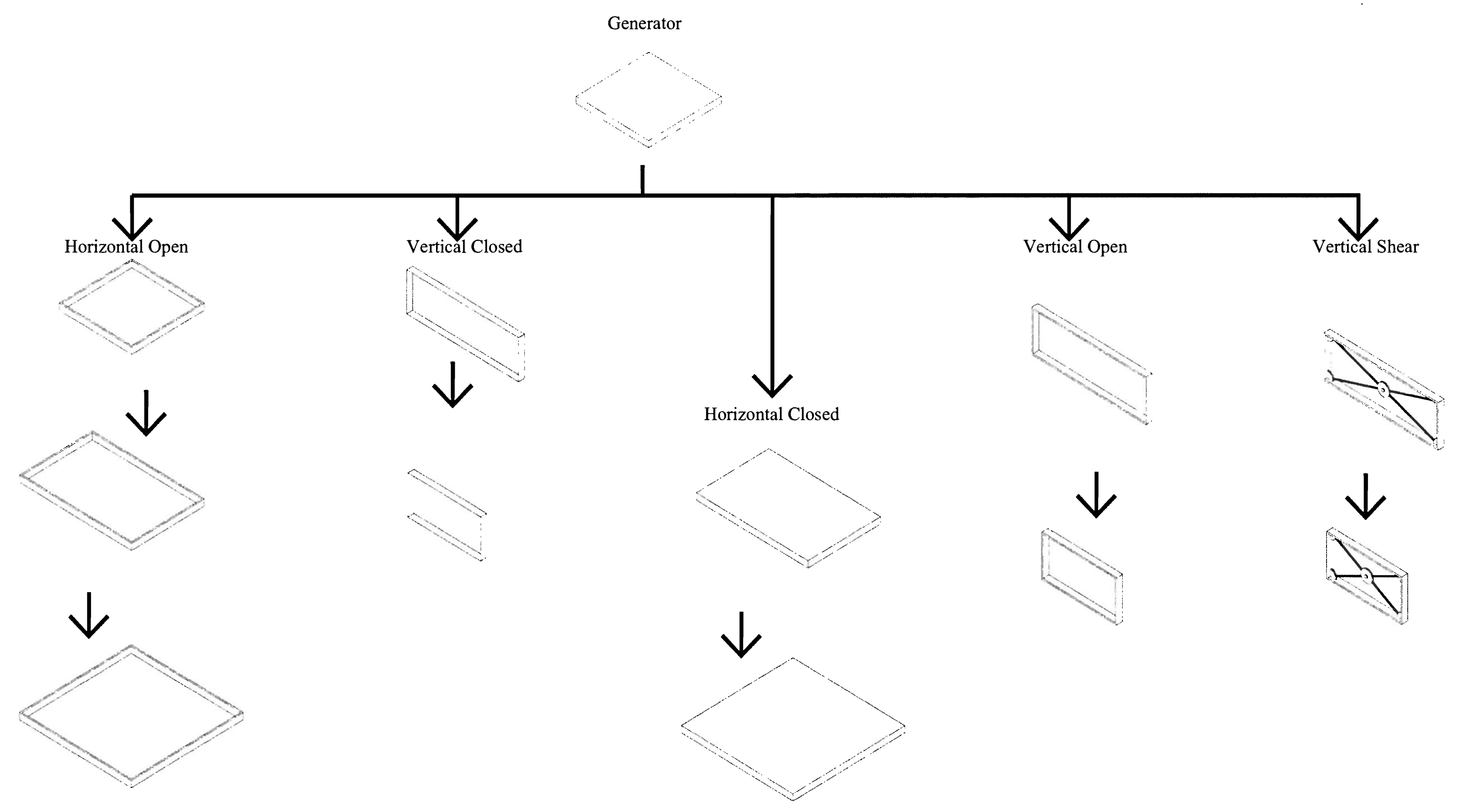




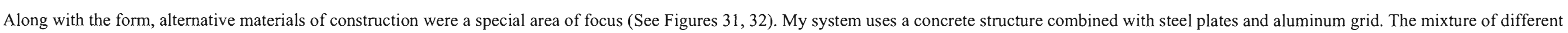

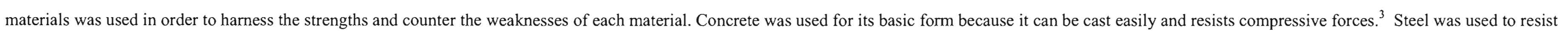
tension and to provide a strong and stable platform for connections. Aluminum was used for its lightweight and ability to be molded into different forms easily. ${ }^{3}$

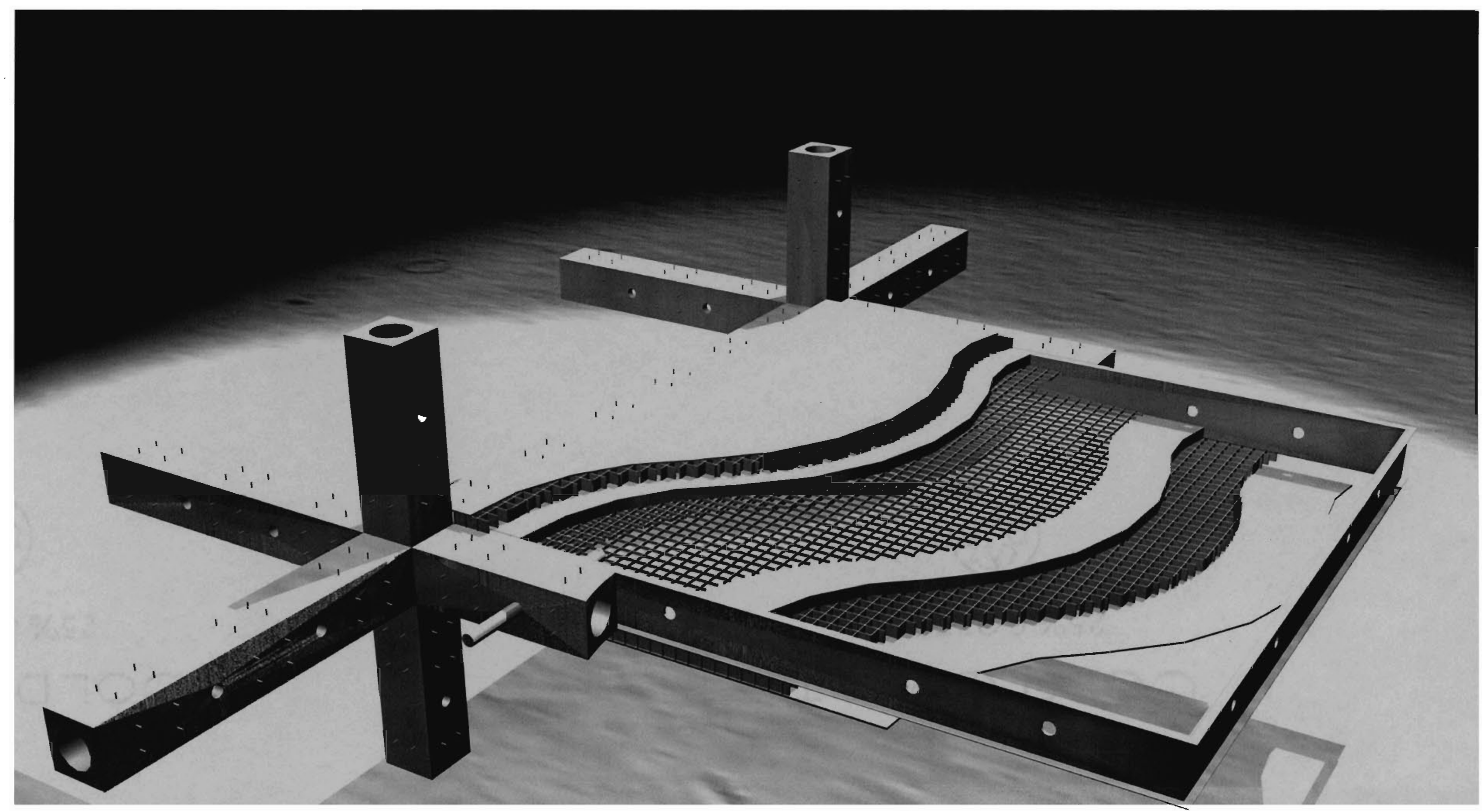




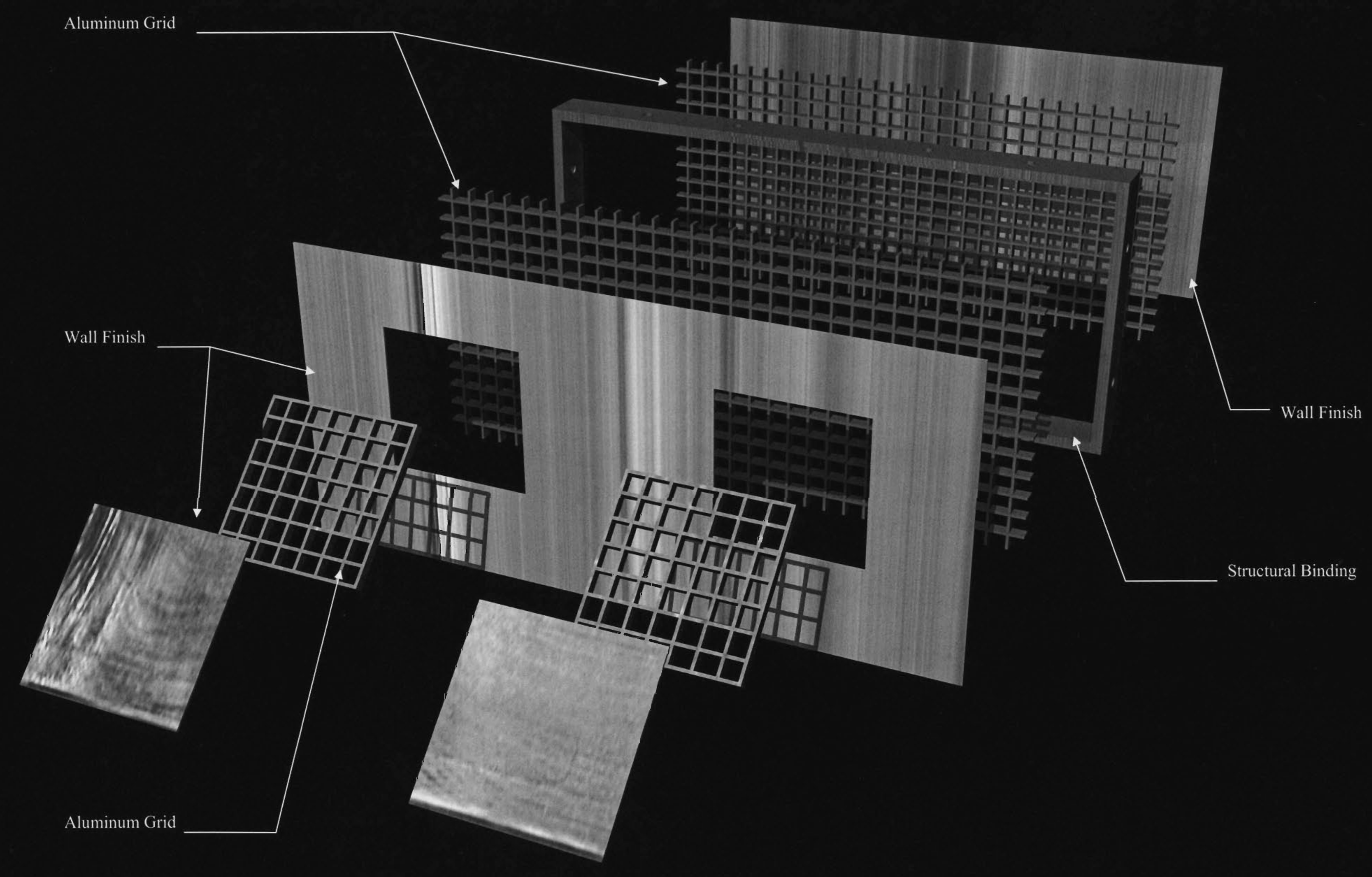


through the insulation blocks (See Figure 33). The floor finish is cut away and the pipe is brought to the unit where it supplies the occupant with mechanical, electrical and plumbing utilities. All utilities are supplied to the unit in this way except the air conditioning, which is brought to the occupant through single wall units.

The last units are the balcony assemblies. (See Figures 34-42) These pieces arrive on the site preconstructed and fit directly onto the facade of the building.

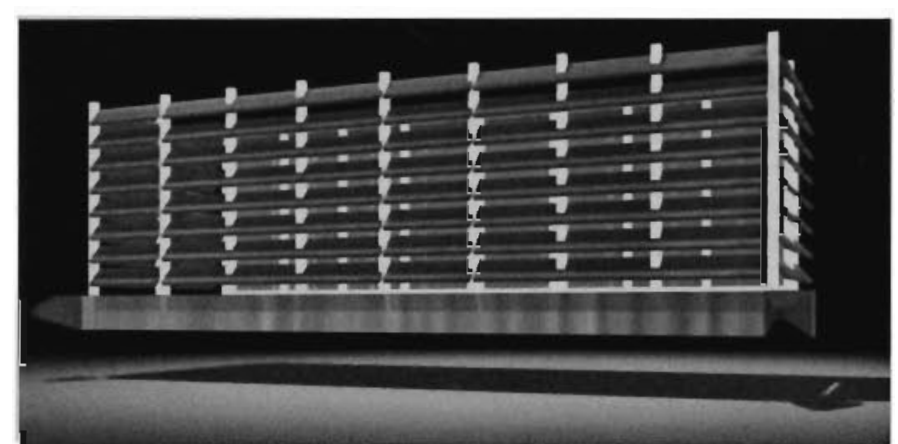

Figure 34 - Louver Balcony Large

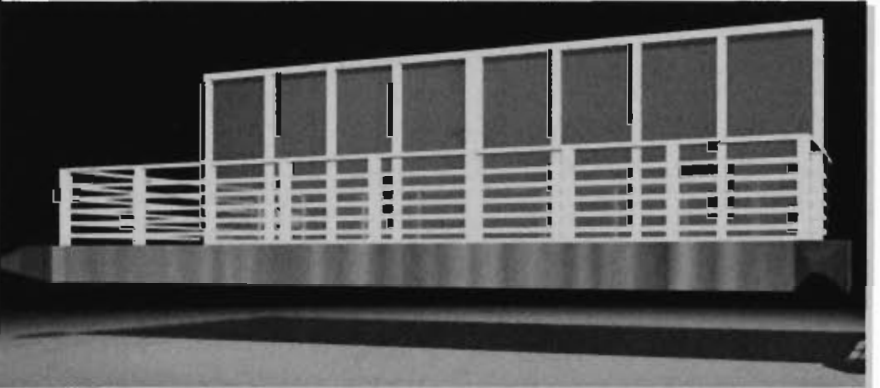

Figure 36 - Railing Balcony Large
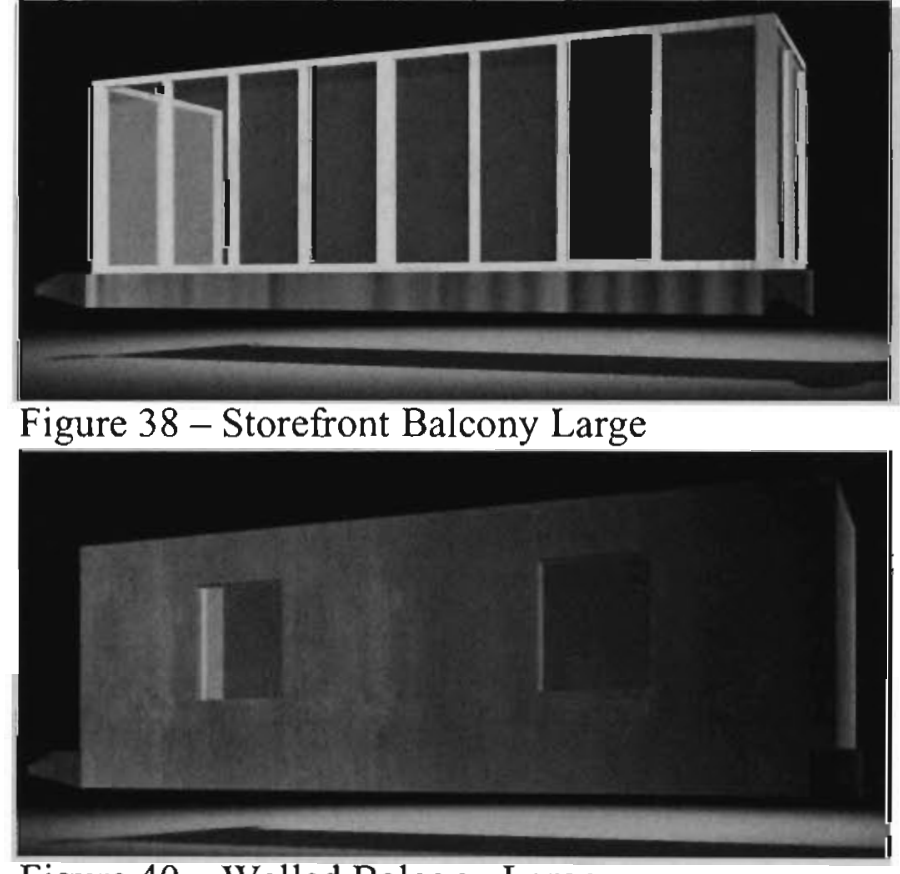

Figure 40 - Walled Balcony Large

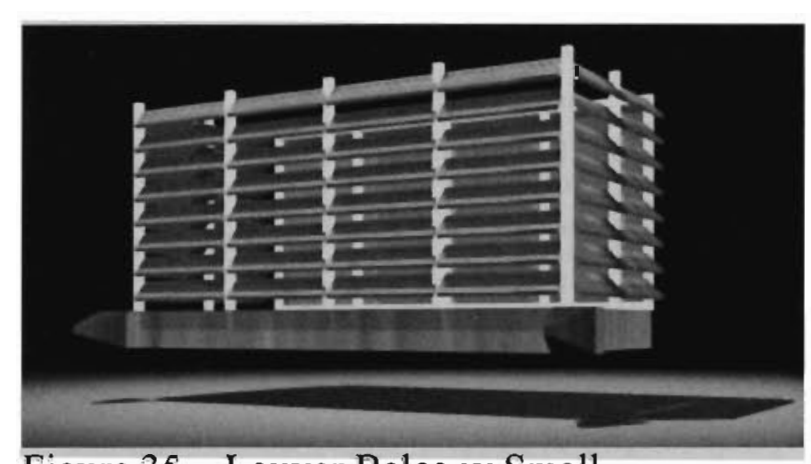

Figure 35 - Louver Balcony Small

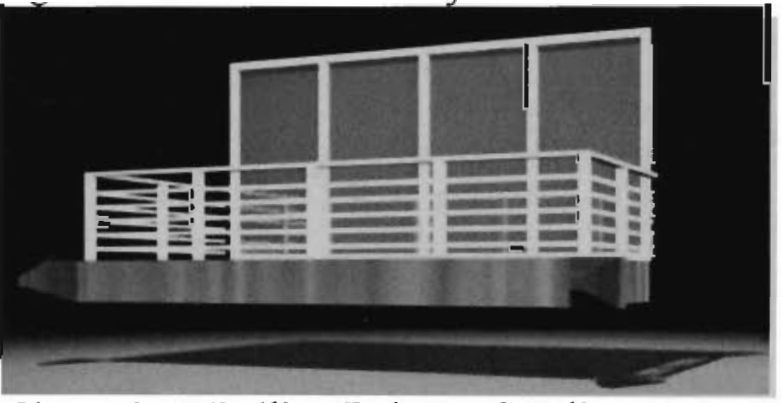

Figure 37 - Railing Balcony Small
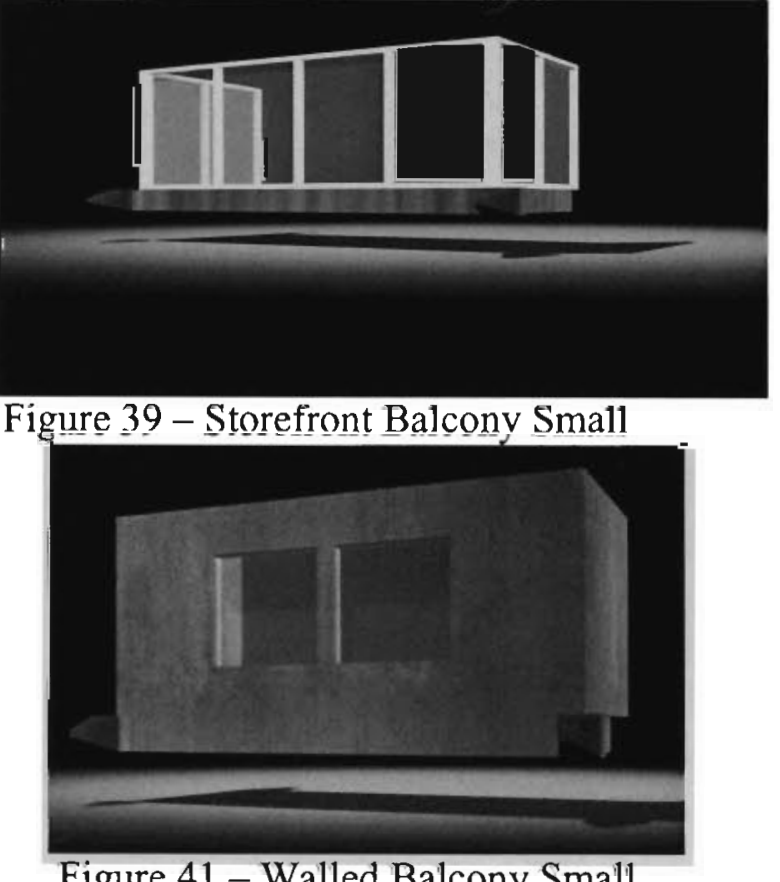

Figure 41 - Walled Balcony Small 

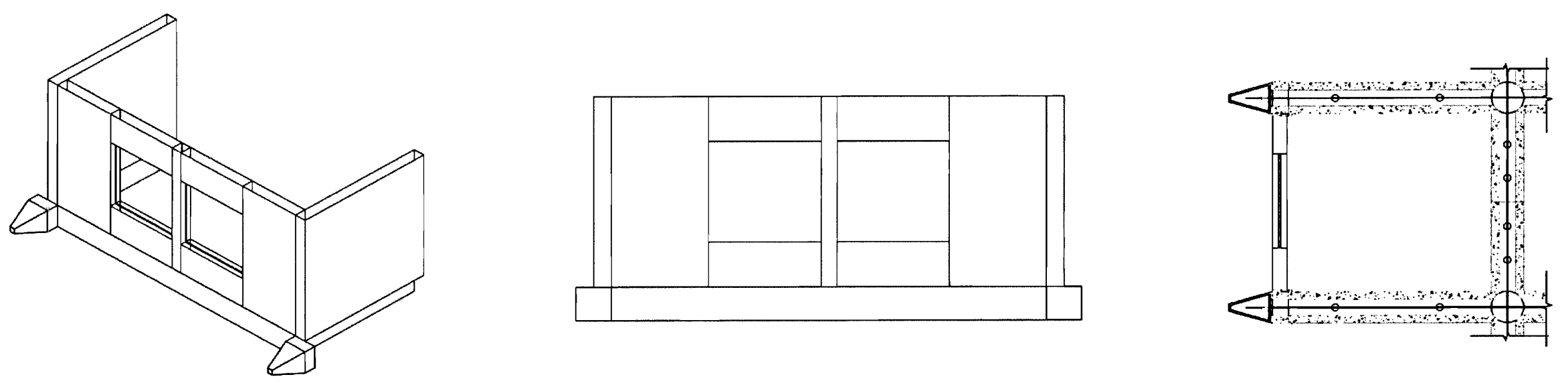

Storefront Balcony
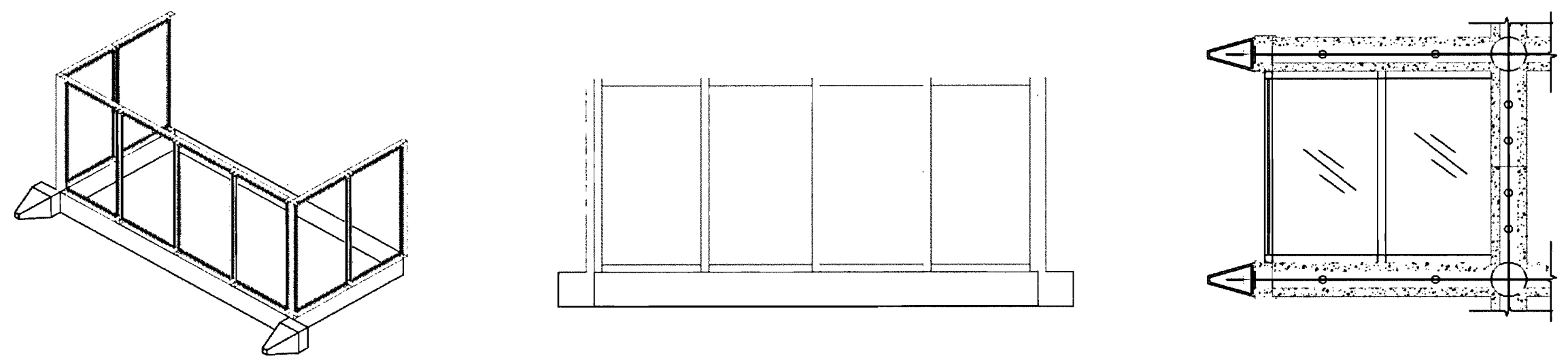

Louvered Balcony
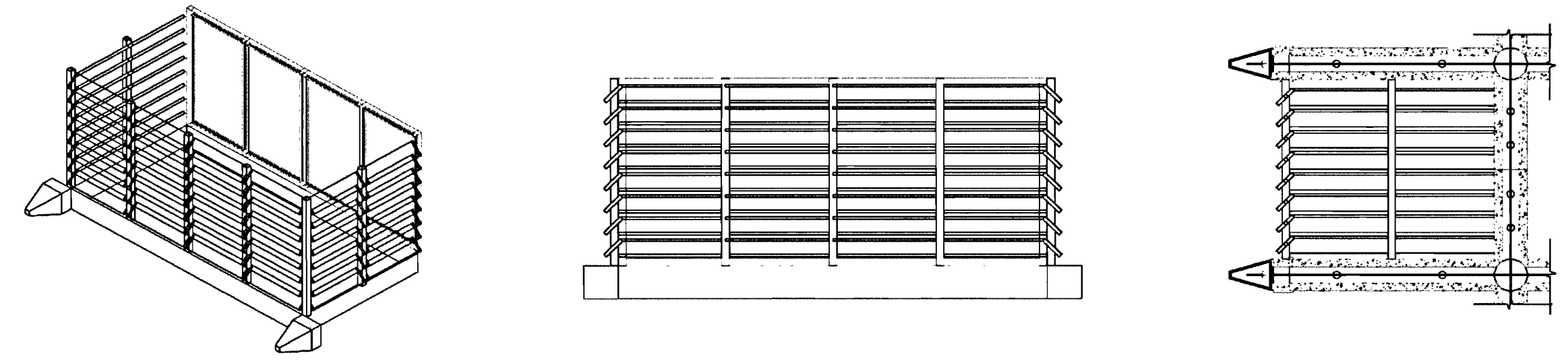

Railing Balcony
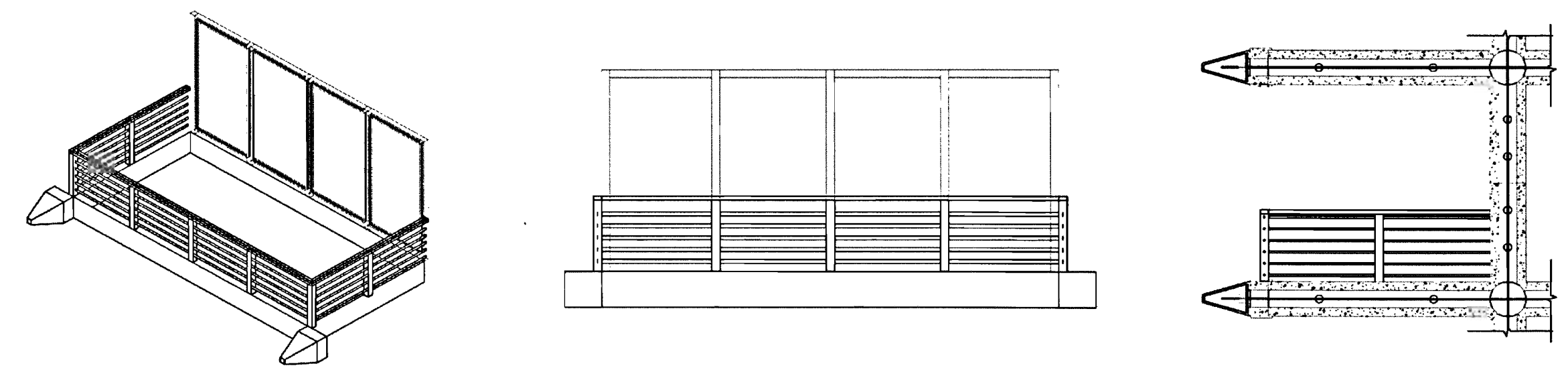


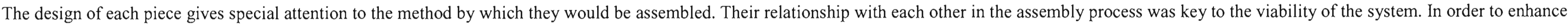

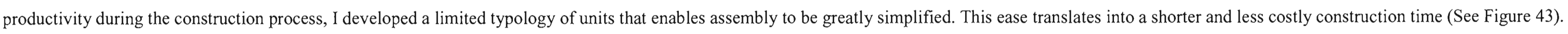

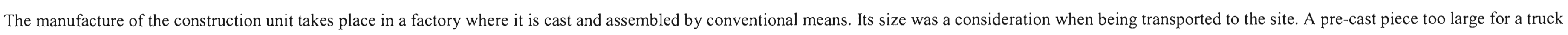

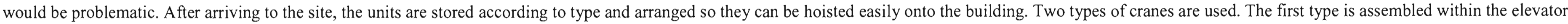

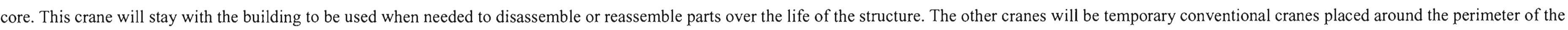
site.

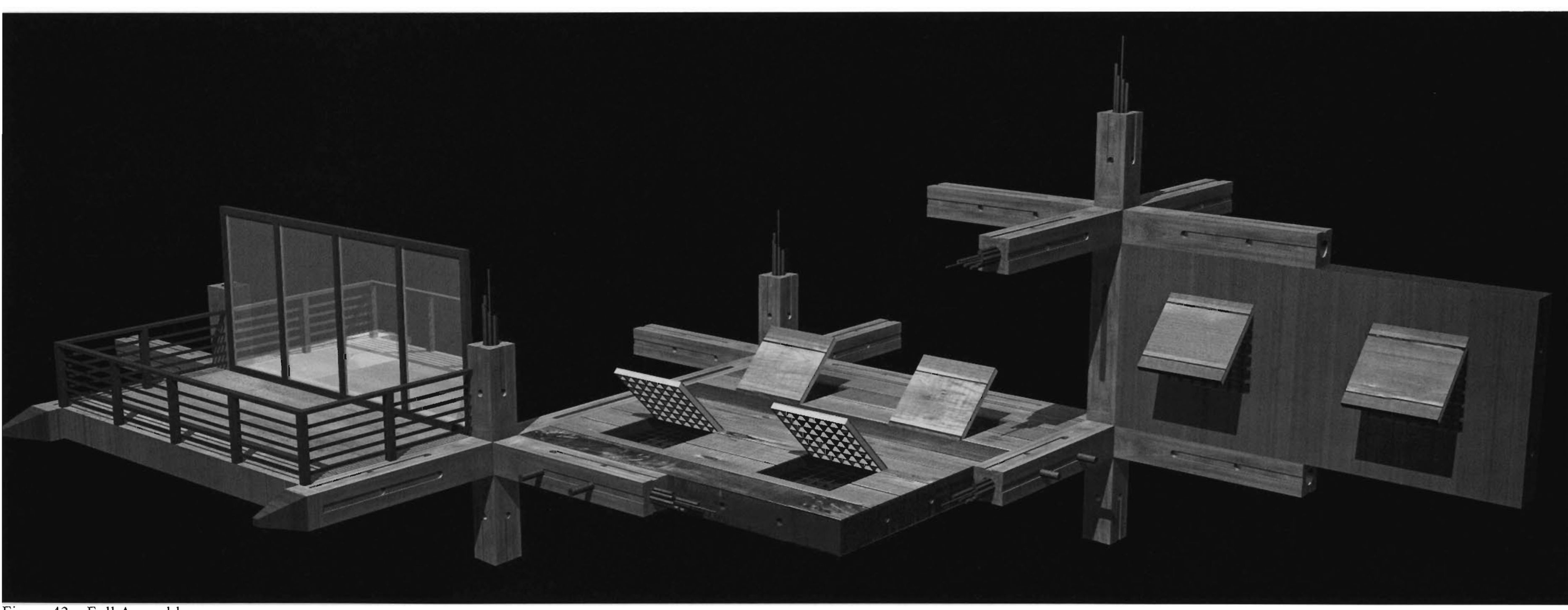

Figure 43 - Full Assembly

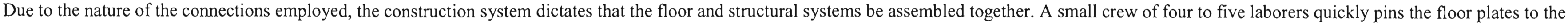

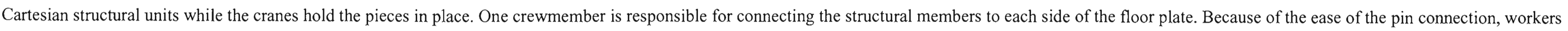

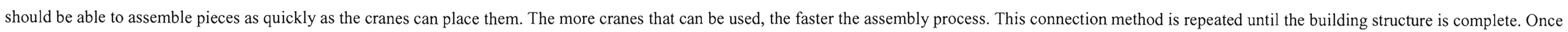



removed and replaced easily by the same process, allowing a high level of customization for apartment tenants.

Through this process a significant amount of time is saved in the construction process, and the system becomes a viable alternative to current construction techniques.

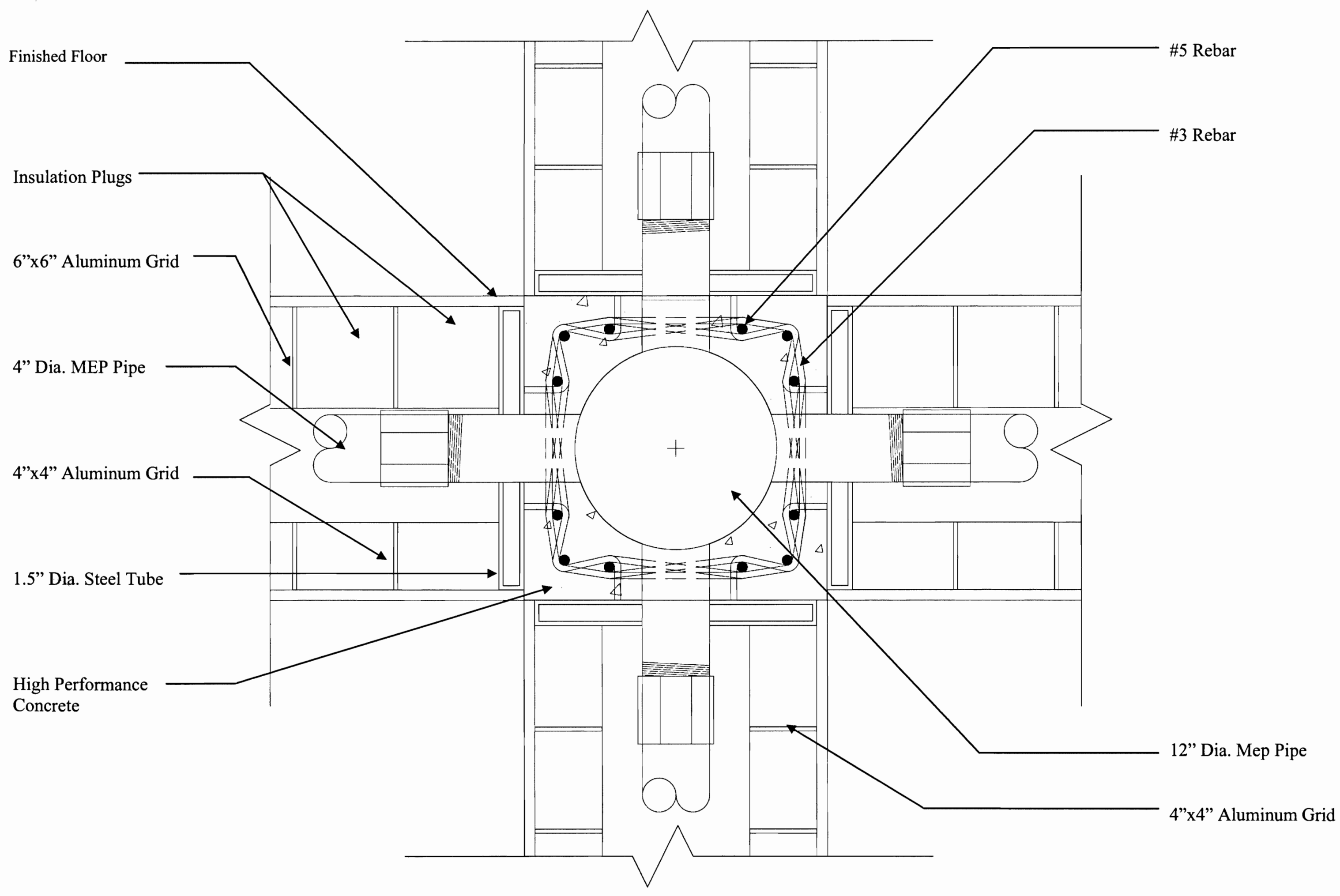



wall. This cap performs the same connection that the plates would accomplish in its place (See Figure 45).

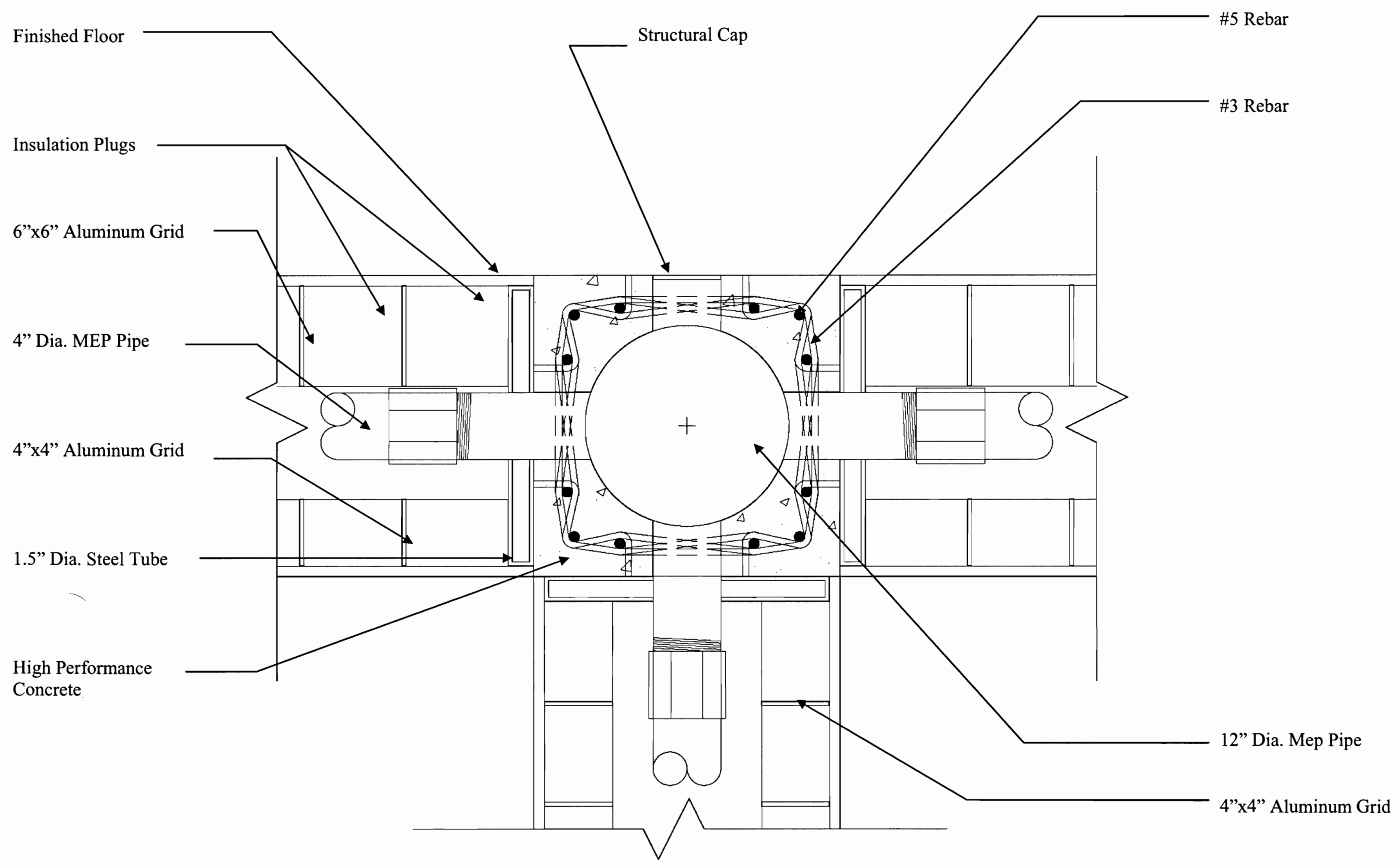




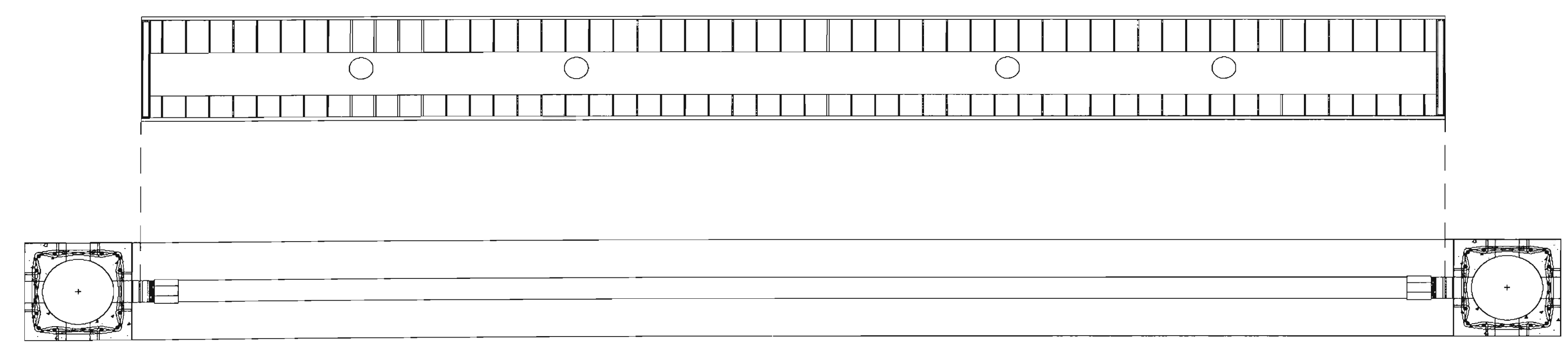

Figure 46 - Assembly Detail

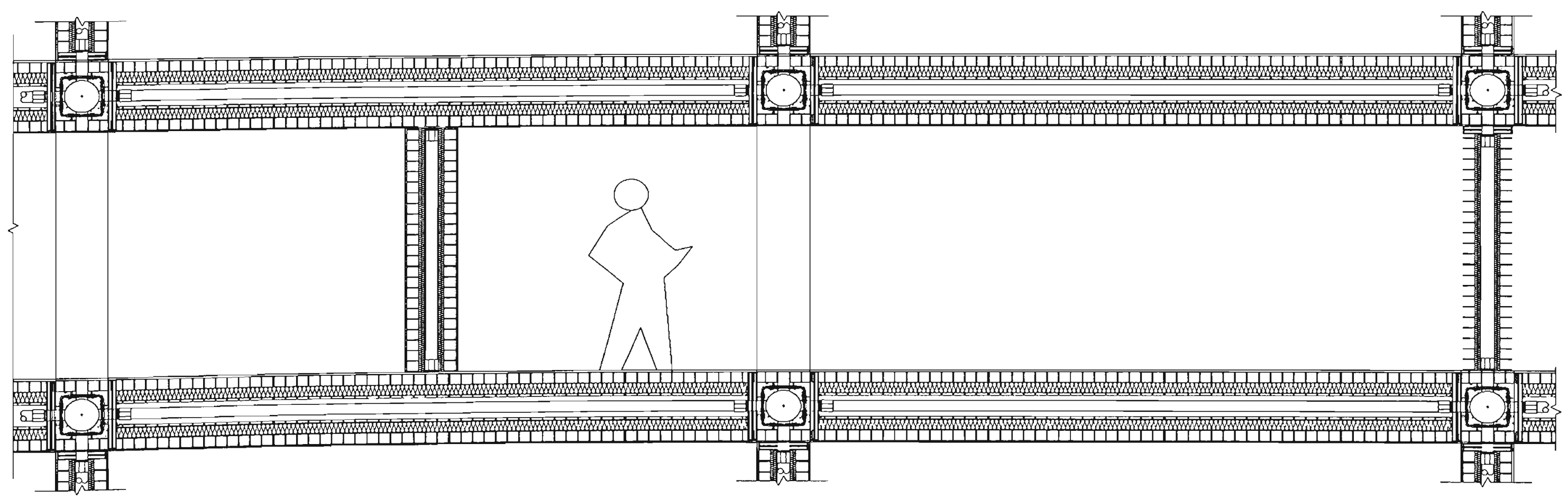

Figure 47 - Unit Section Detail 


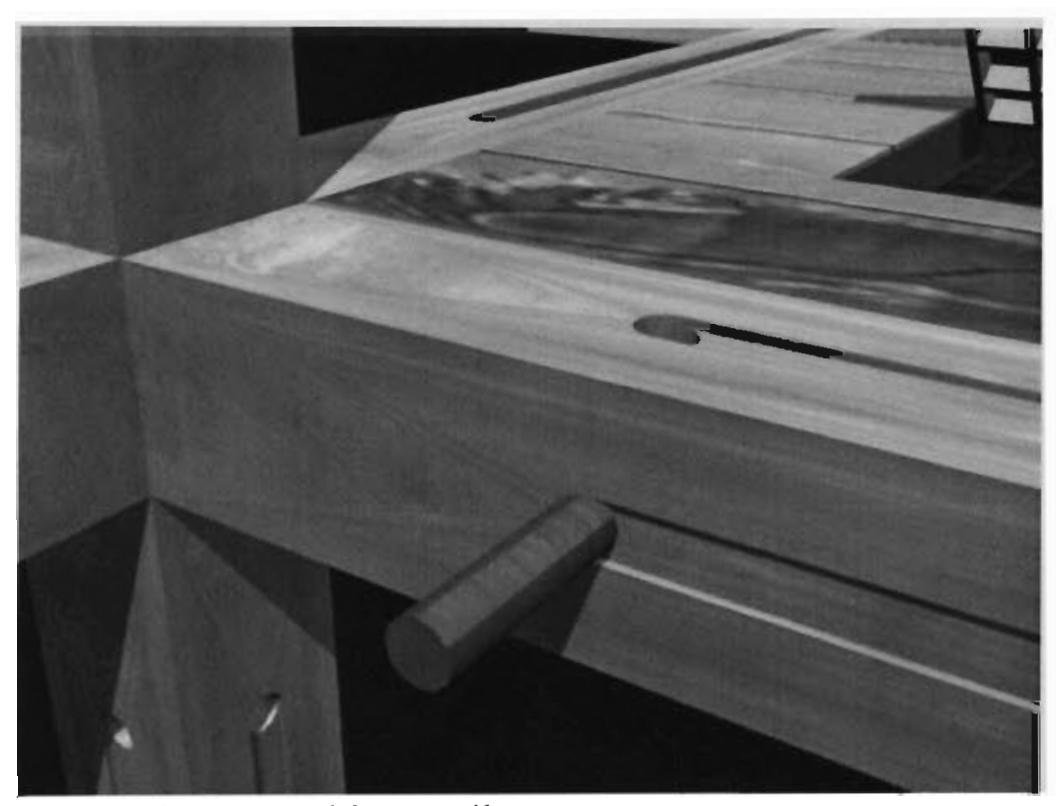

Figure 48 - Assembly Detail

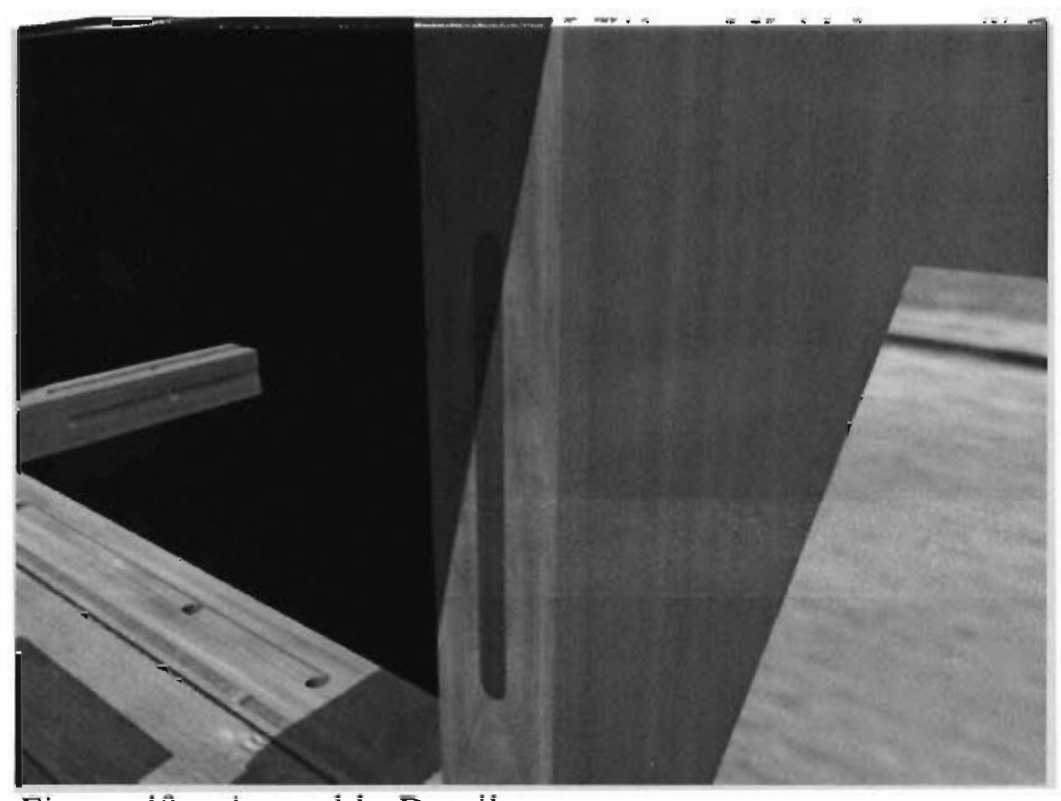

Figure 49 - Assembly Detail

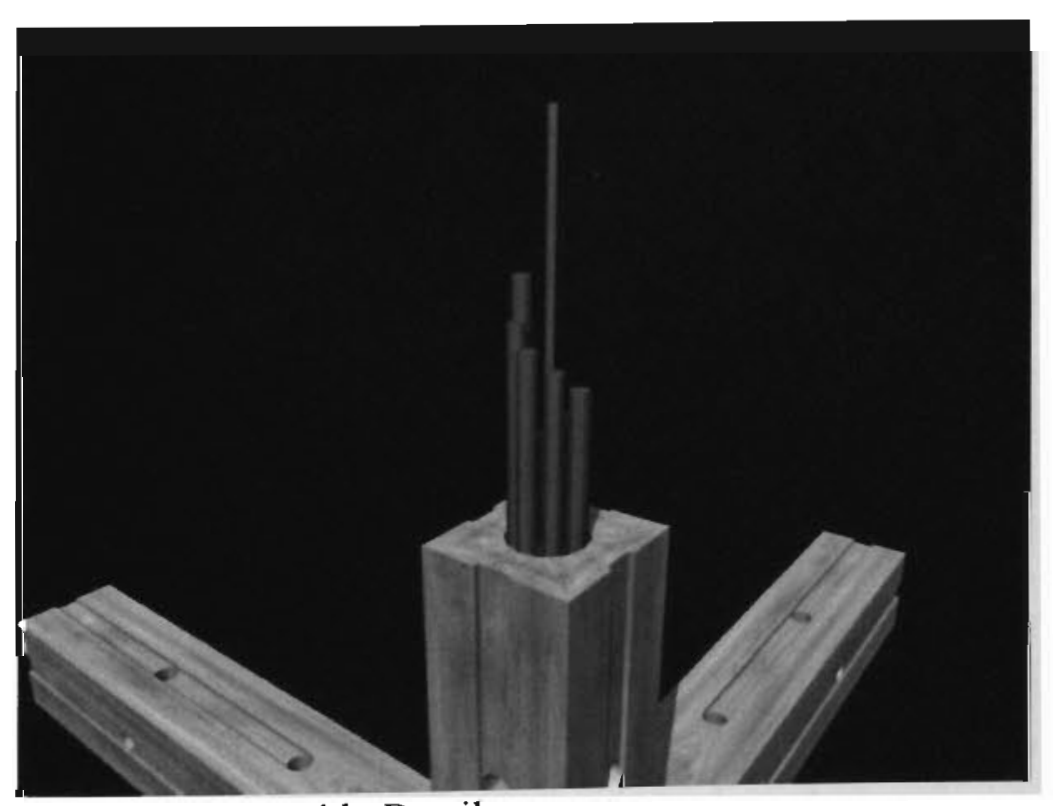

Figure 50 - Assembly Detail

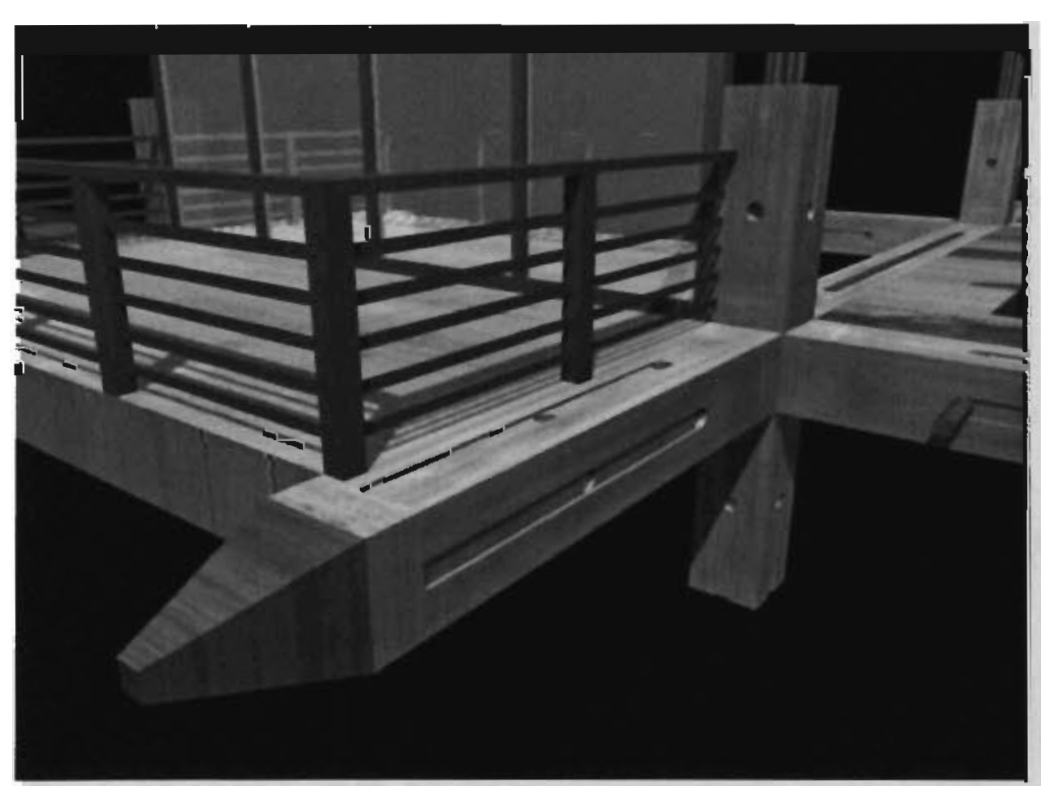

Figure 51 - Assembly Detail

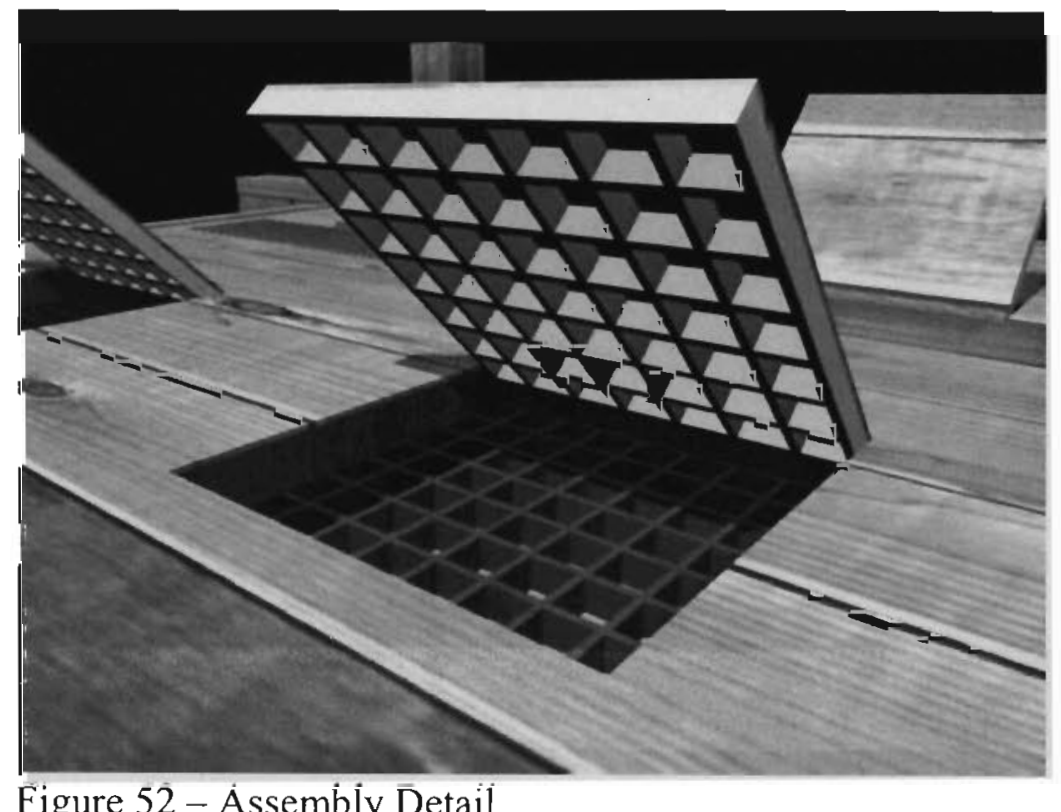

Figure 52 - Assembly Detail 


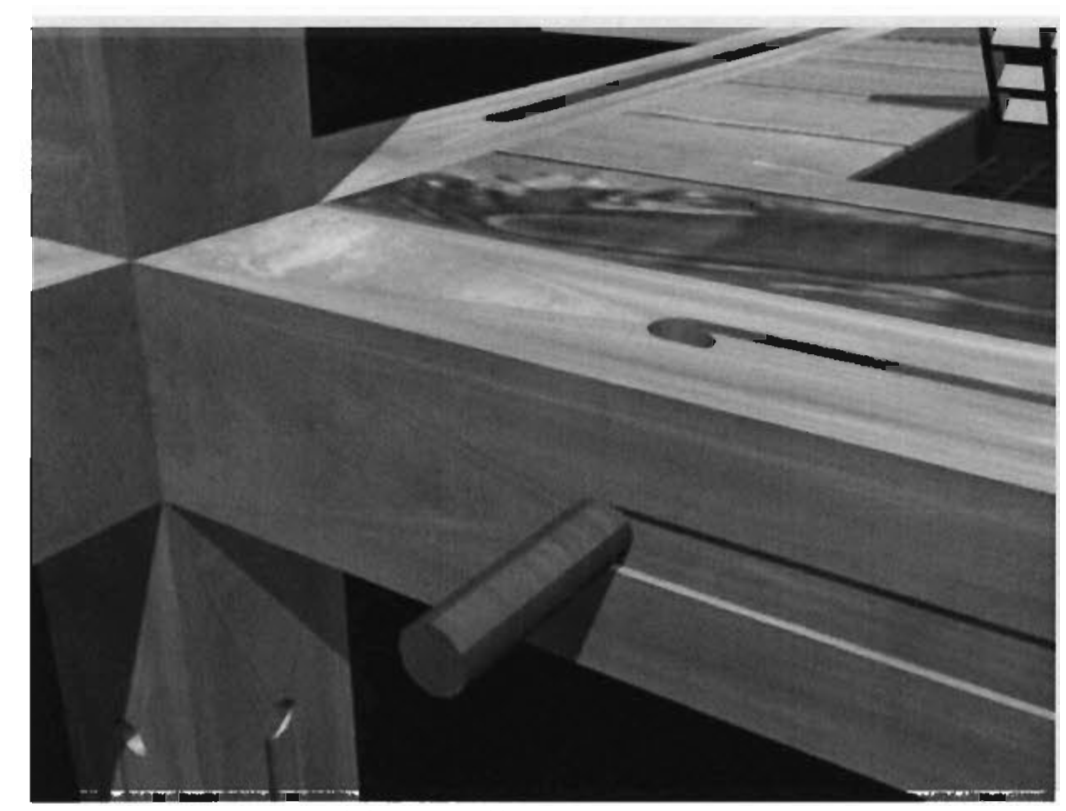

Figure 48 - Assembly Detail

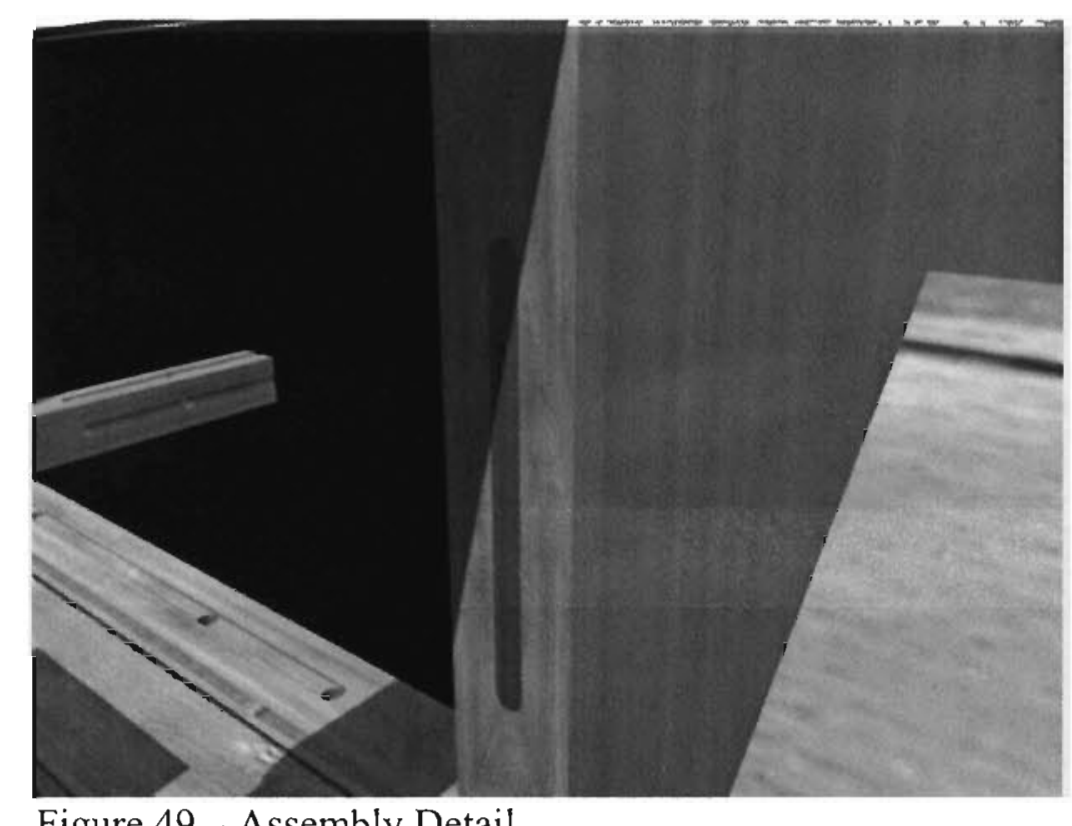

Figure 49 - Assembly Detail

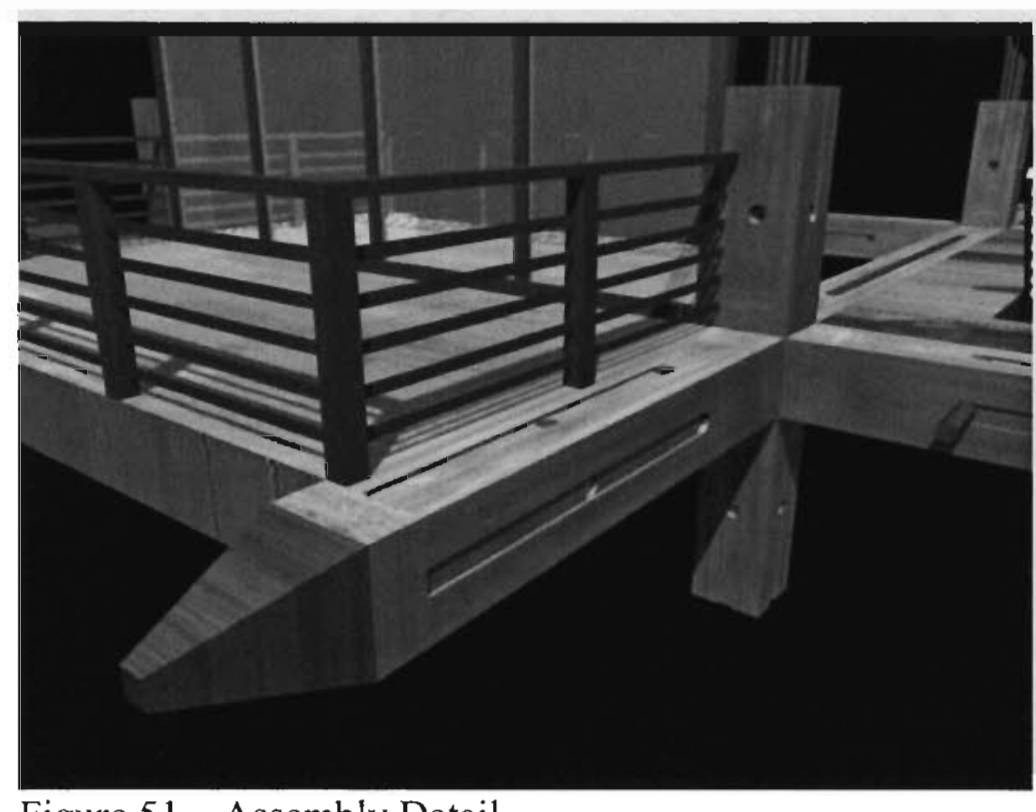

Figure 51 - Assembly Detail

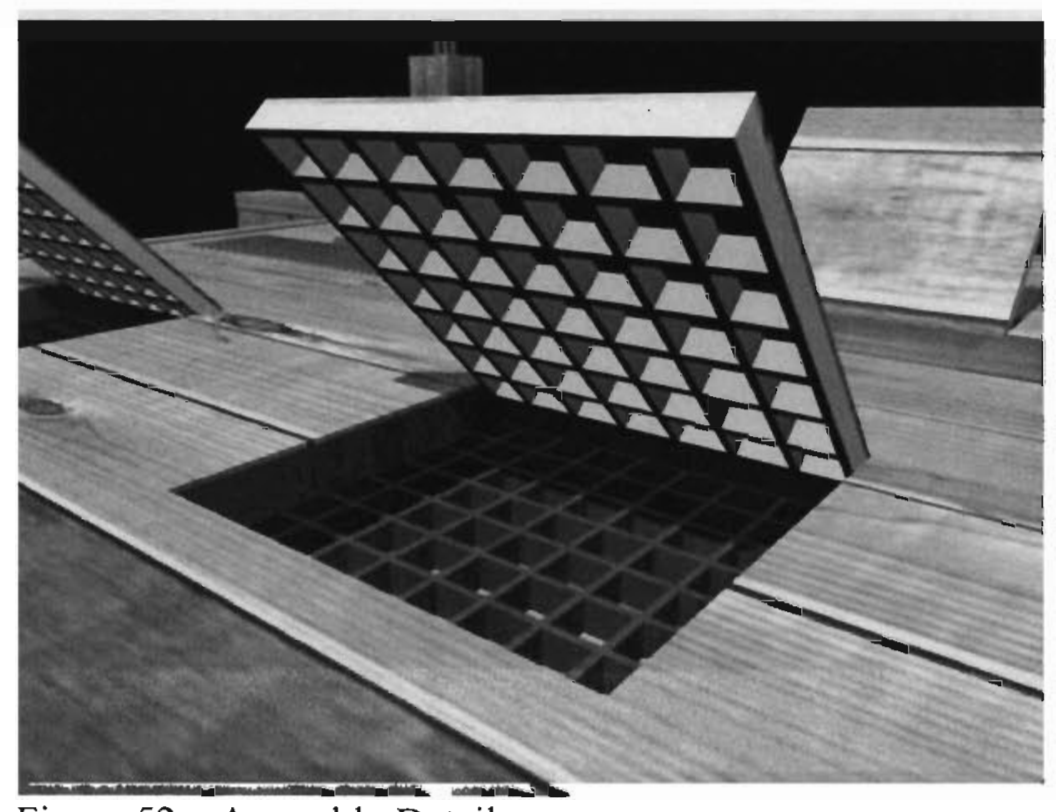

Figure 52 - Assembly Detail 


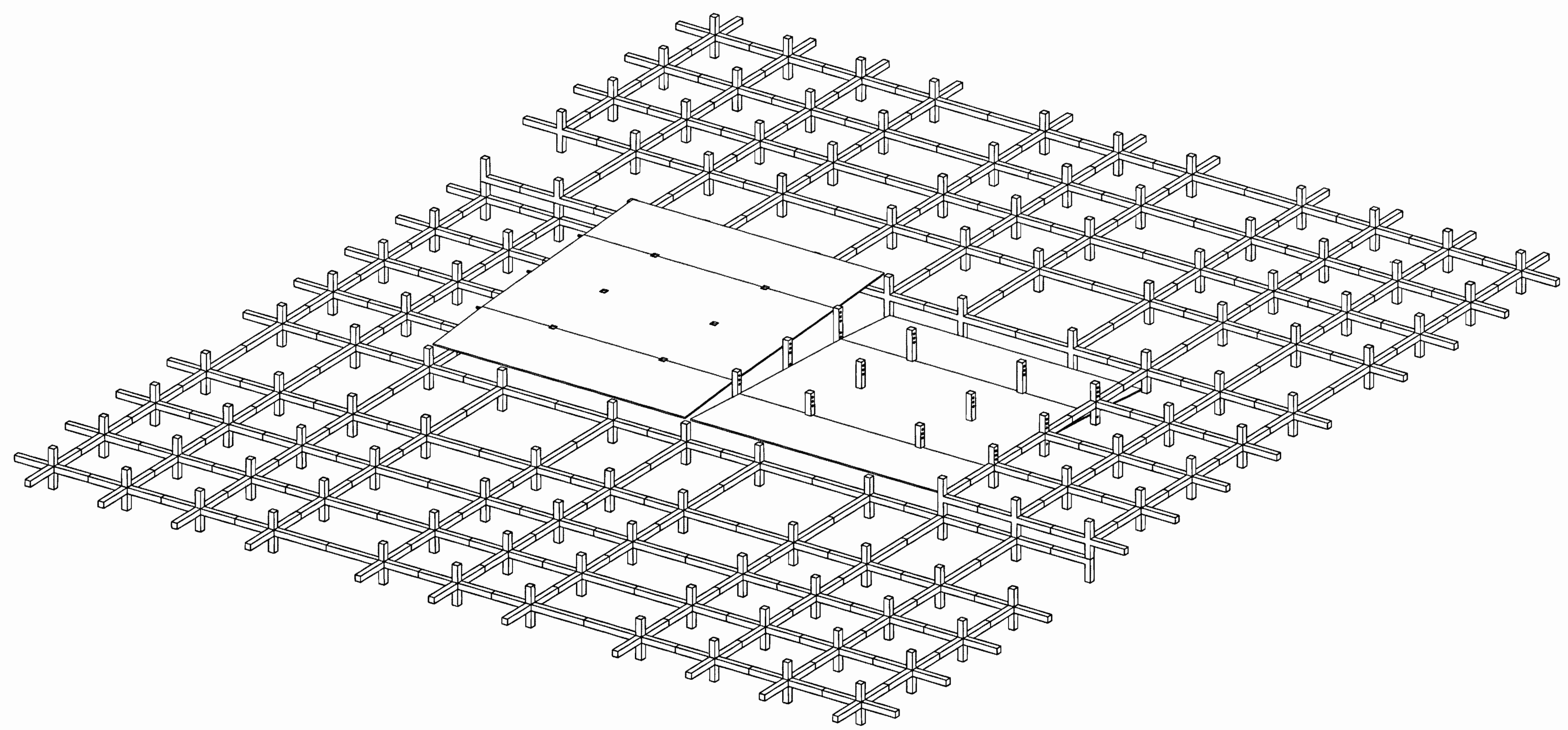




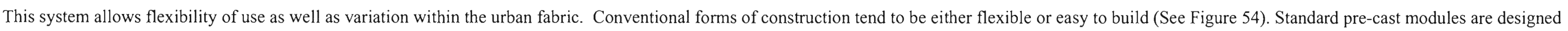

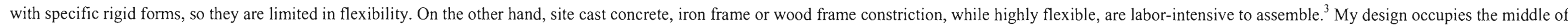

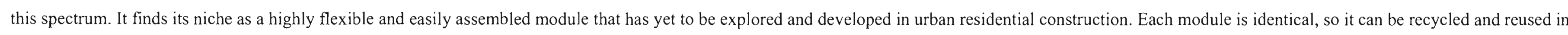

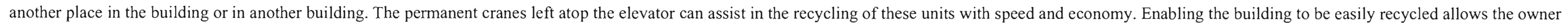
and tenant to respond with fluidity to changes within the urban landscape and adds a layer of economic flexibility to the entire system.

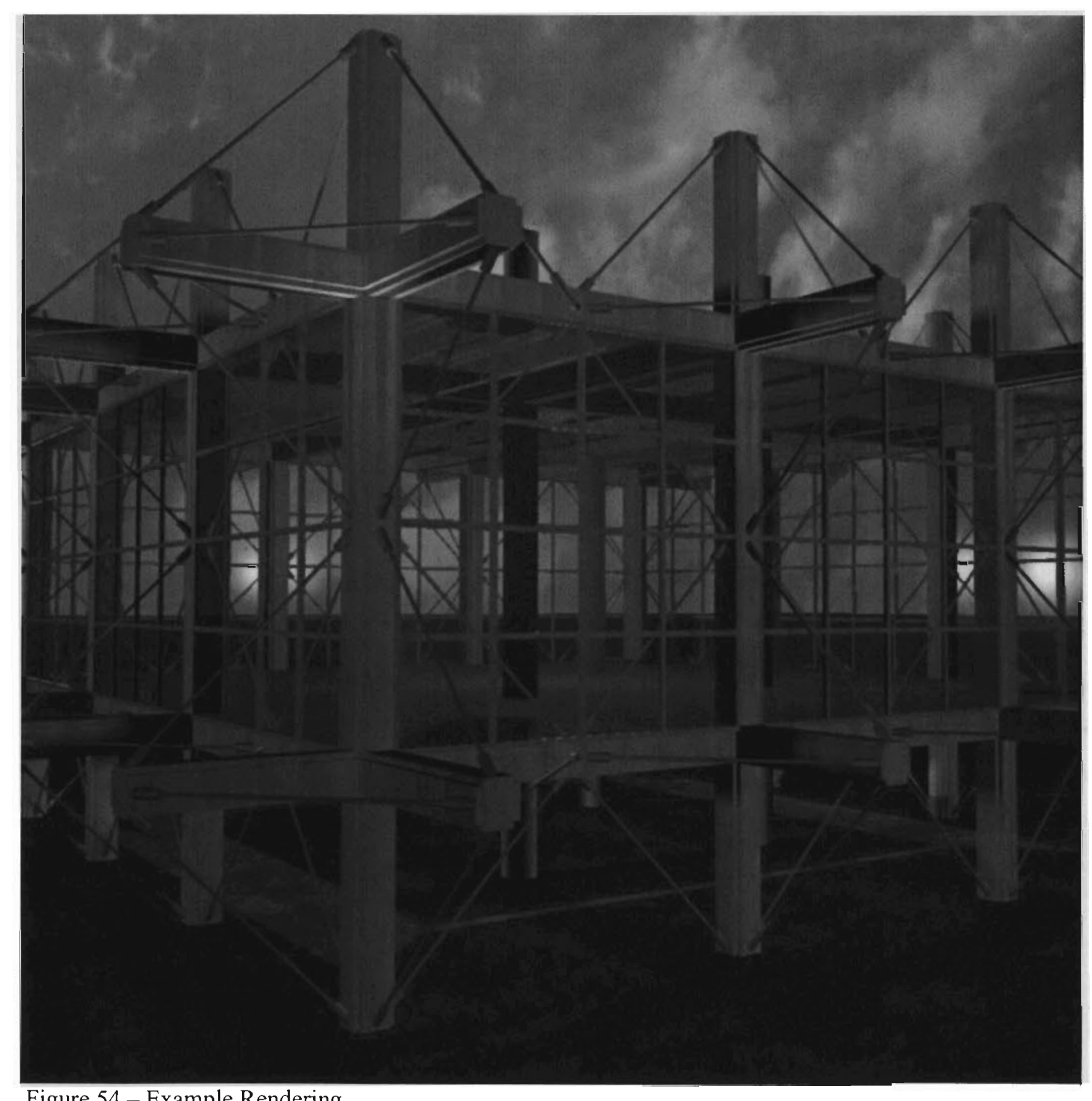




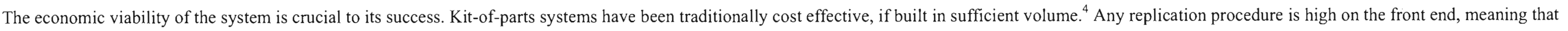

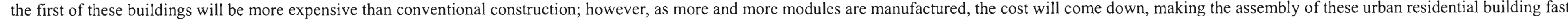

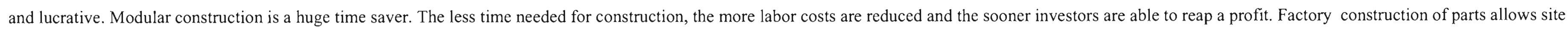

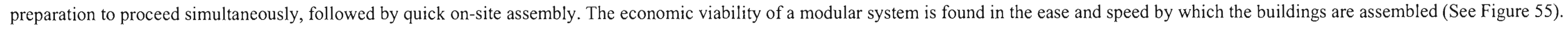

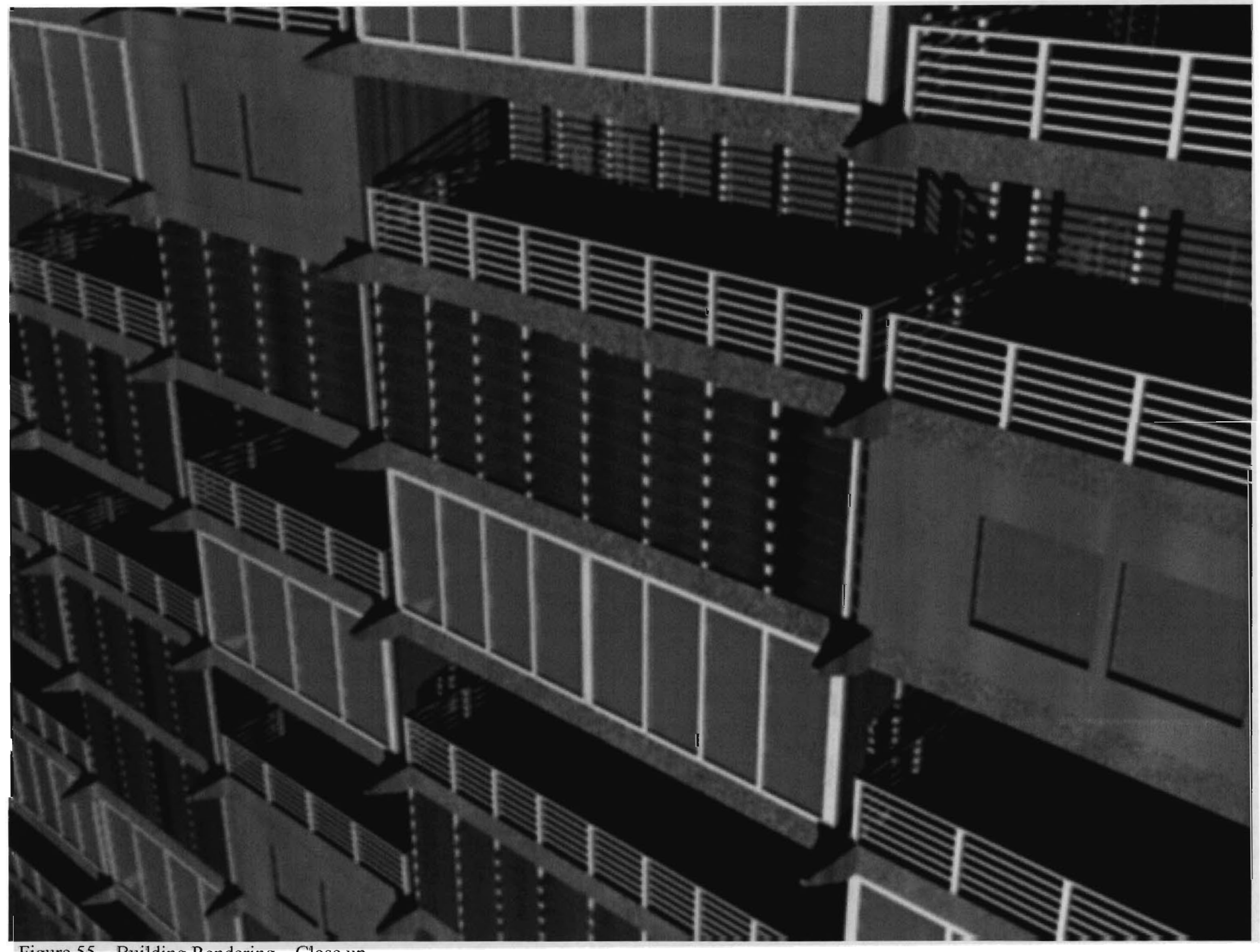




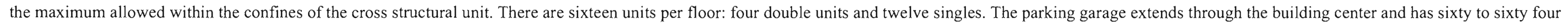
parking spaces per floor depending on the needs for accessibility (See Figures 55-71).

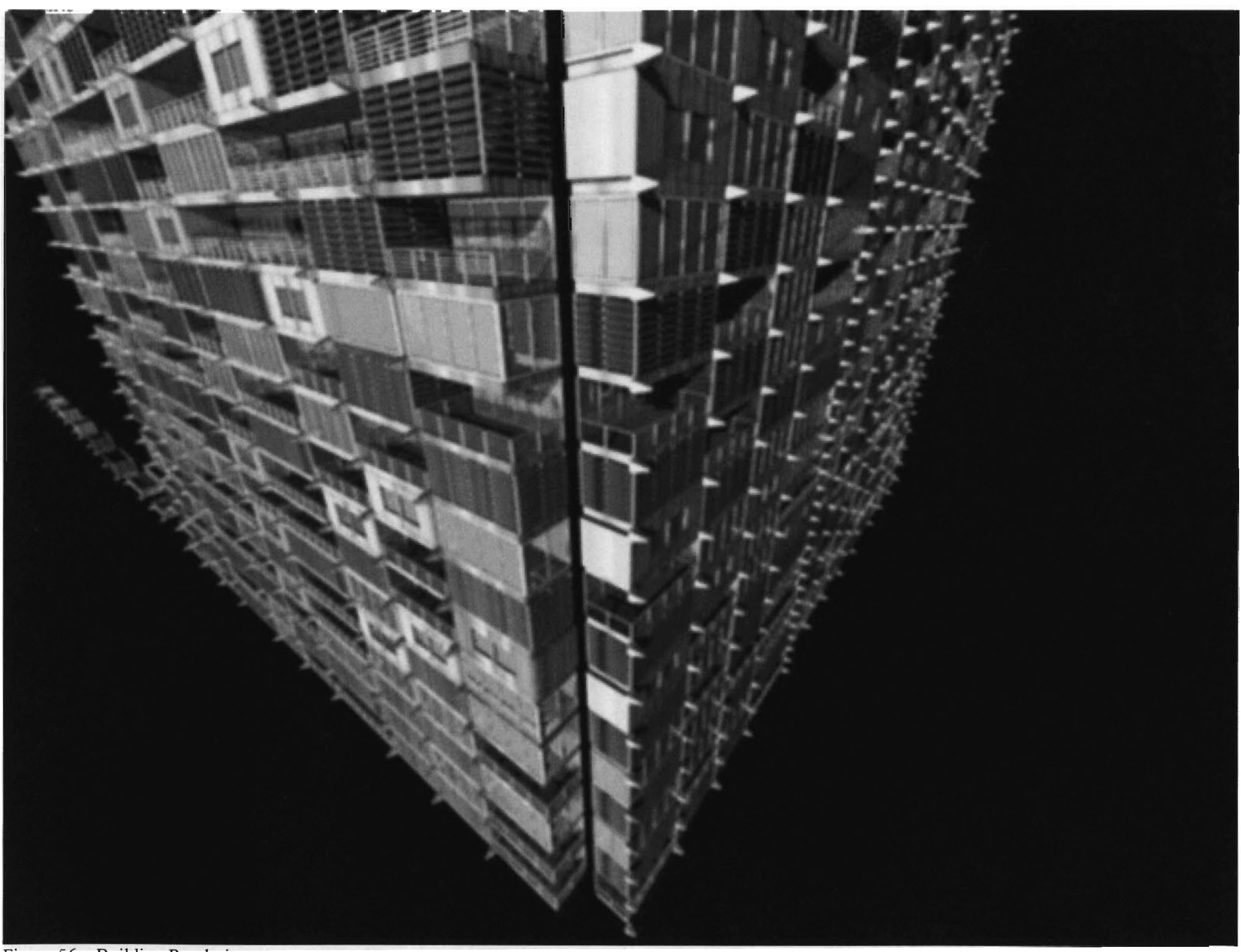




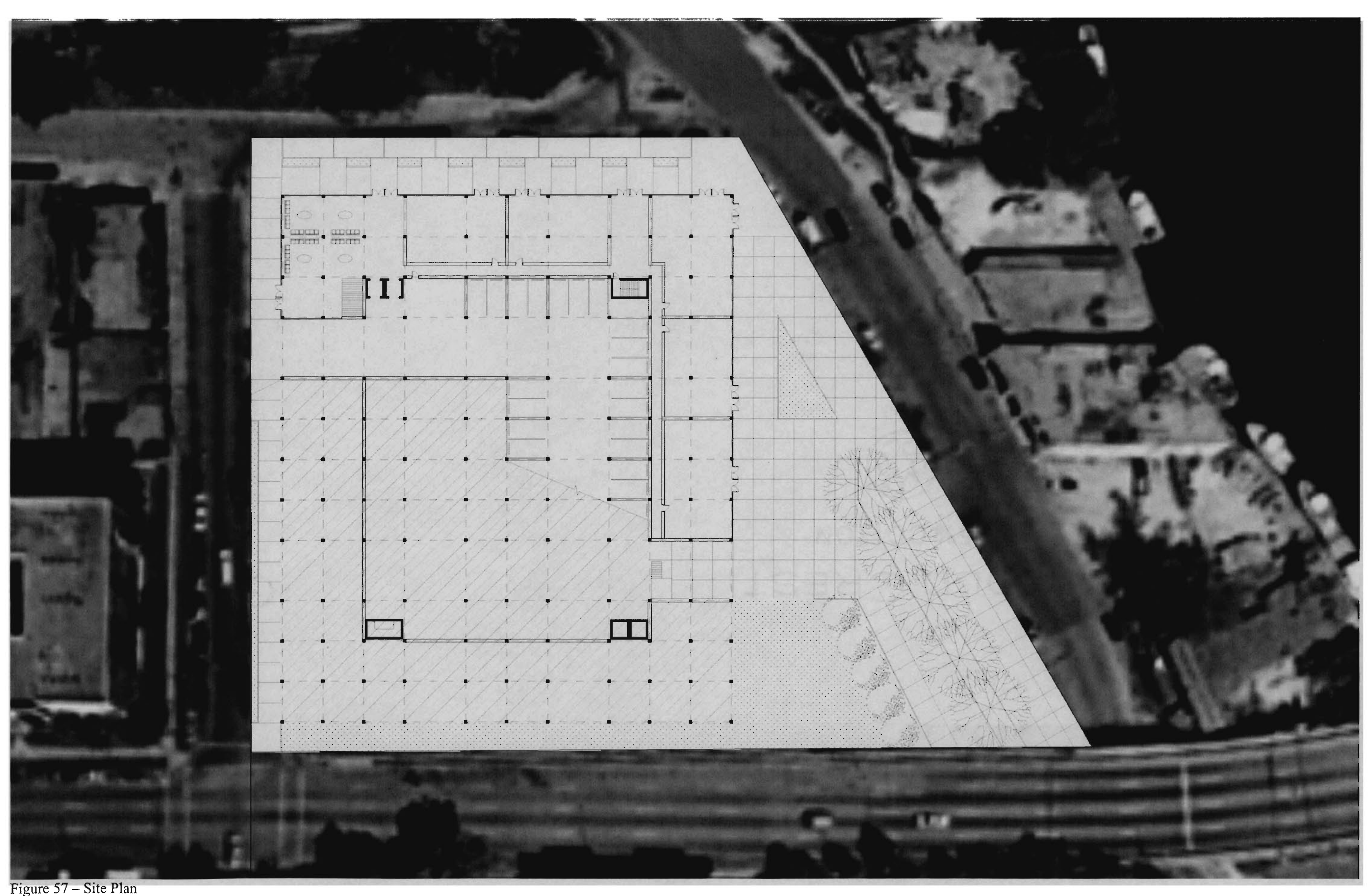




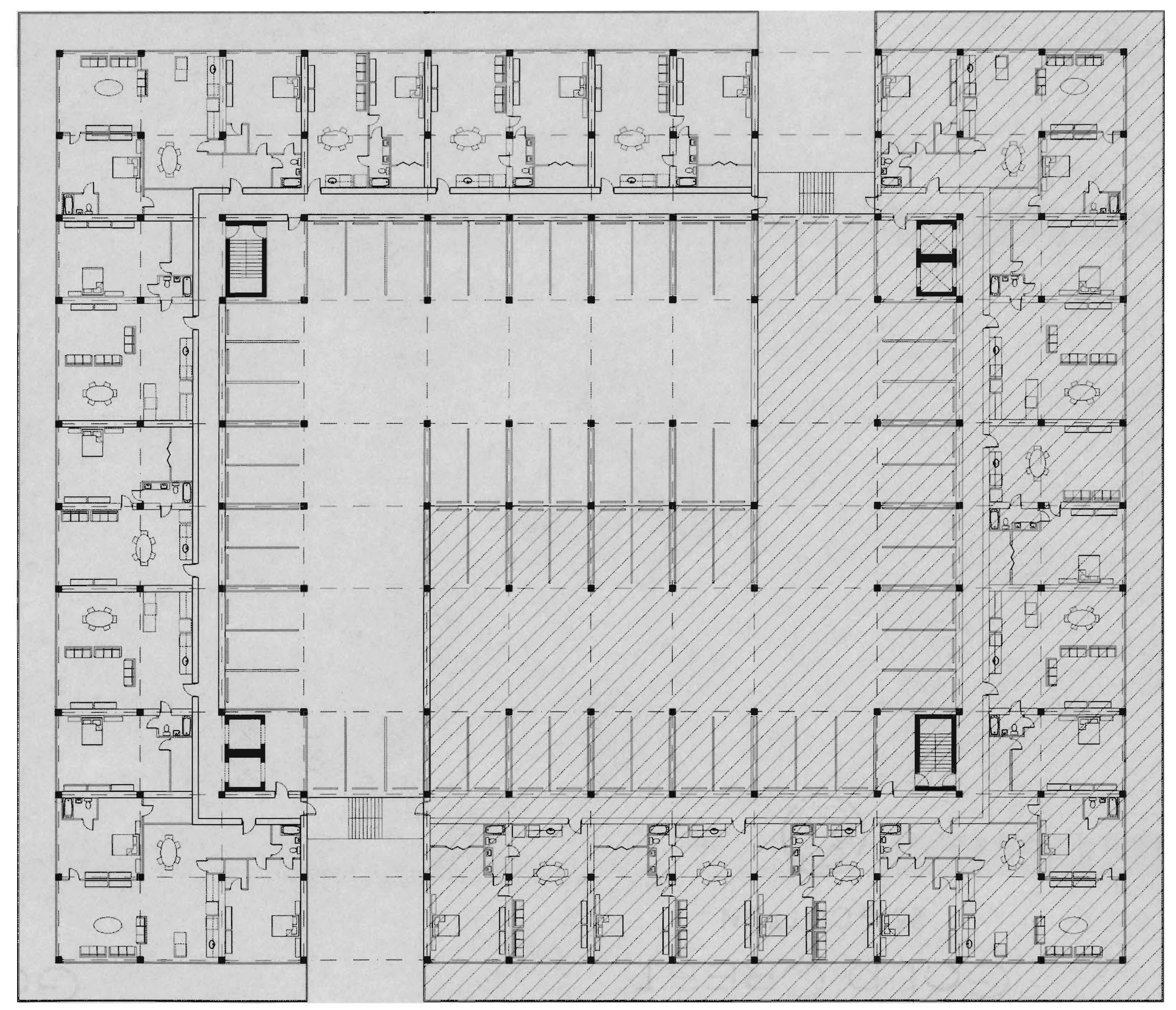

Figure 58 - Typical Plan A 


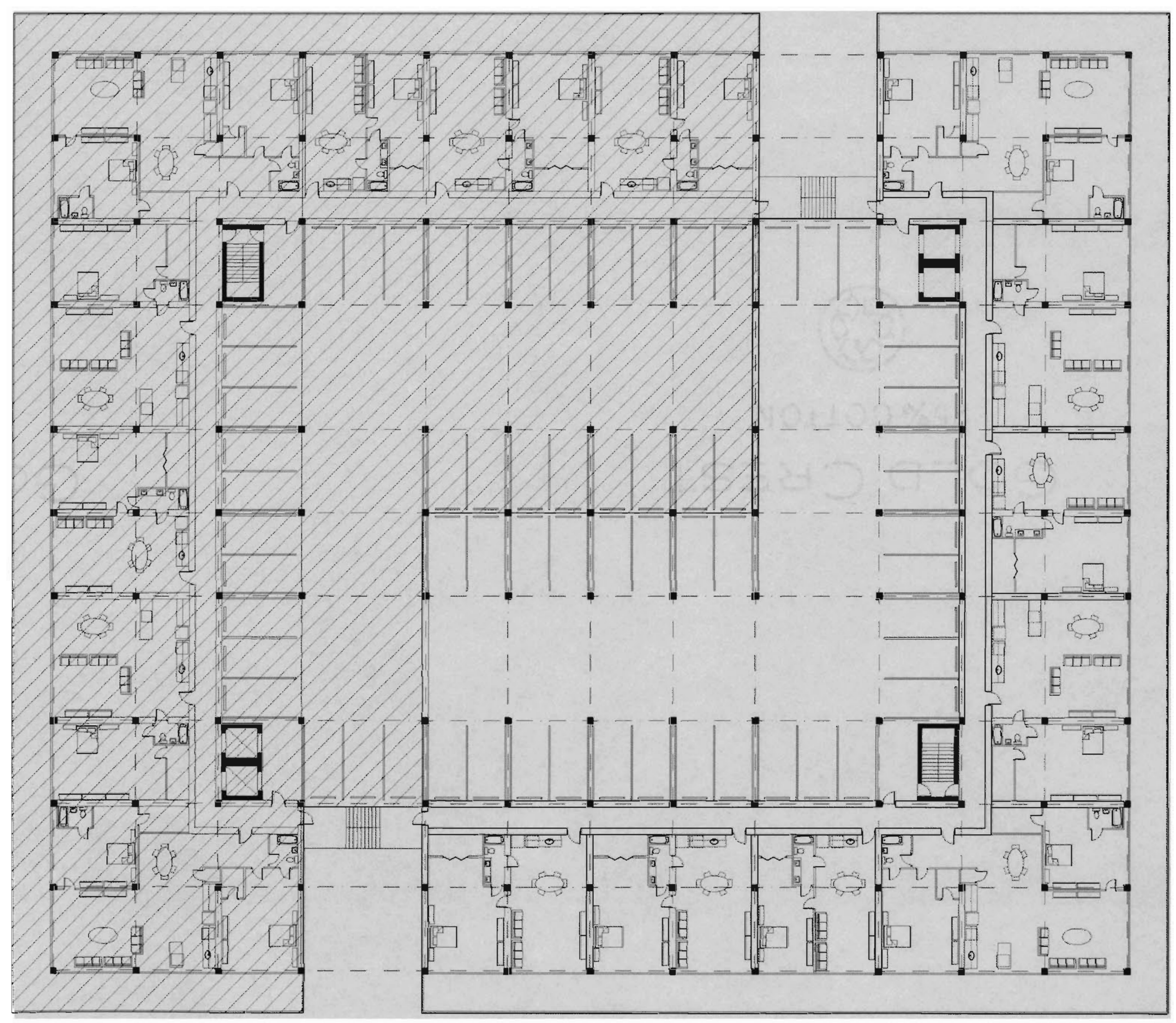




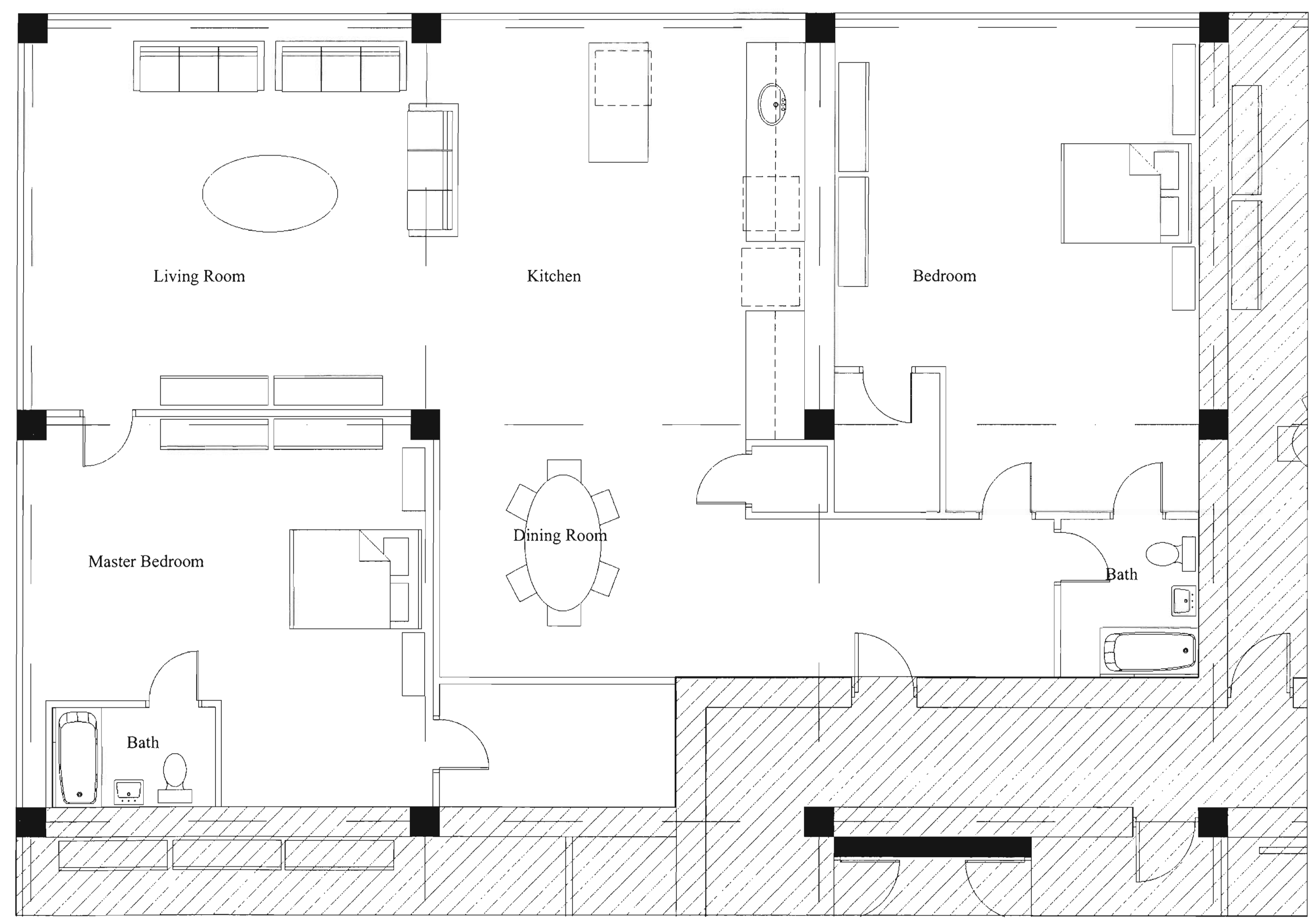

Figure 60 - Typical Double Unit 


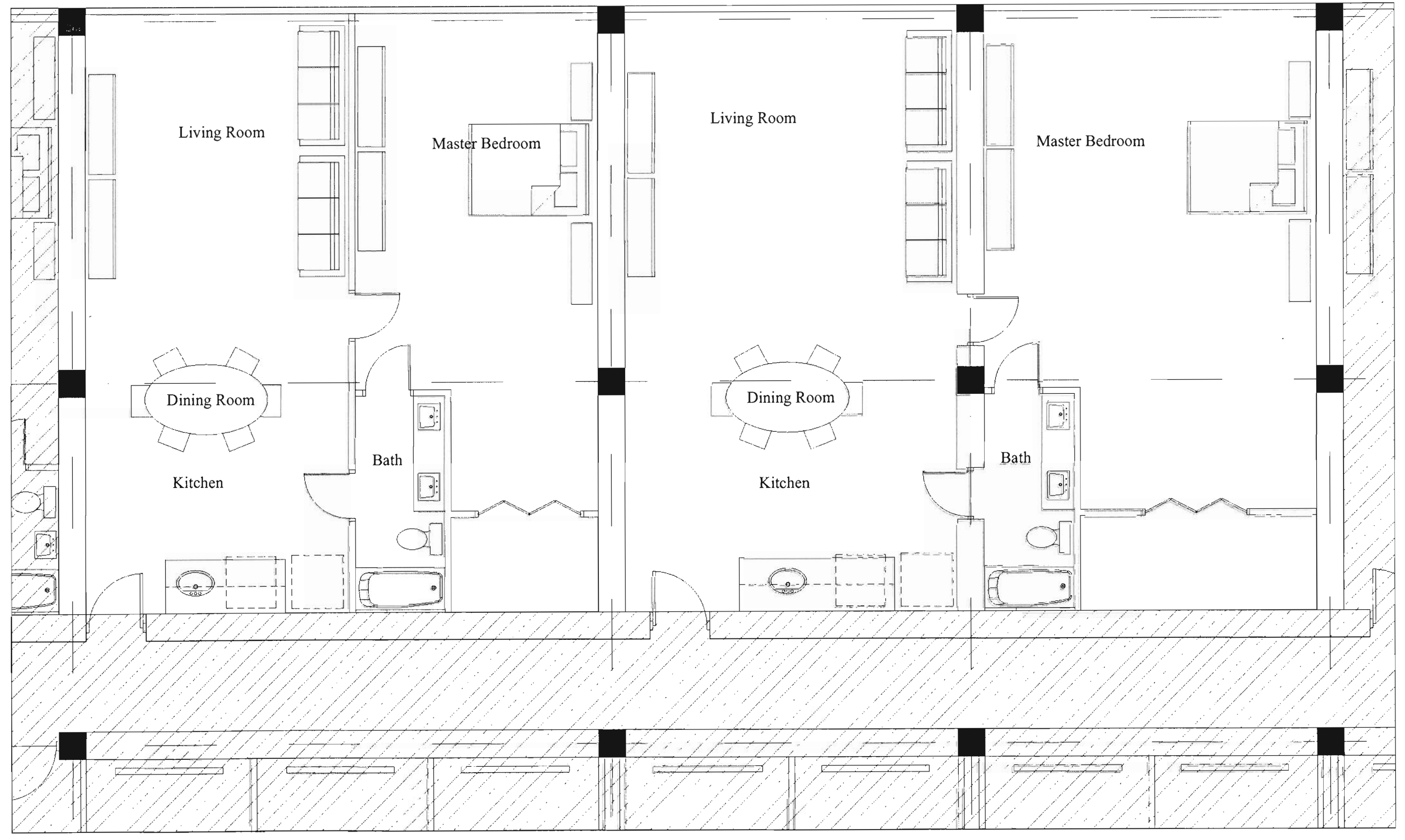

Figure 61 - Typical Single Unit A and B 


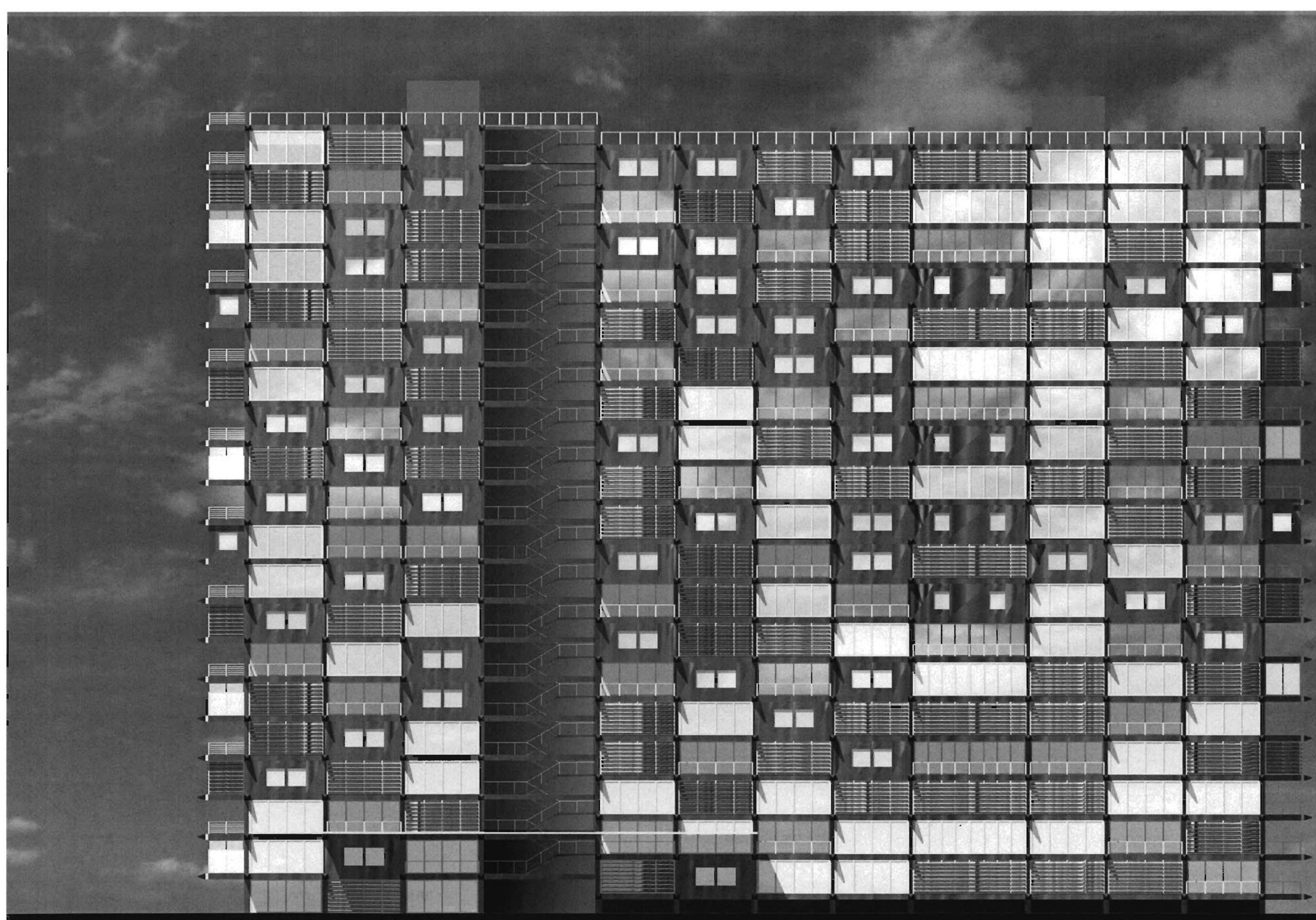




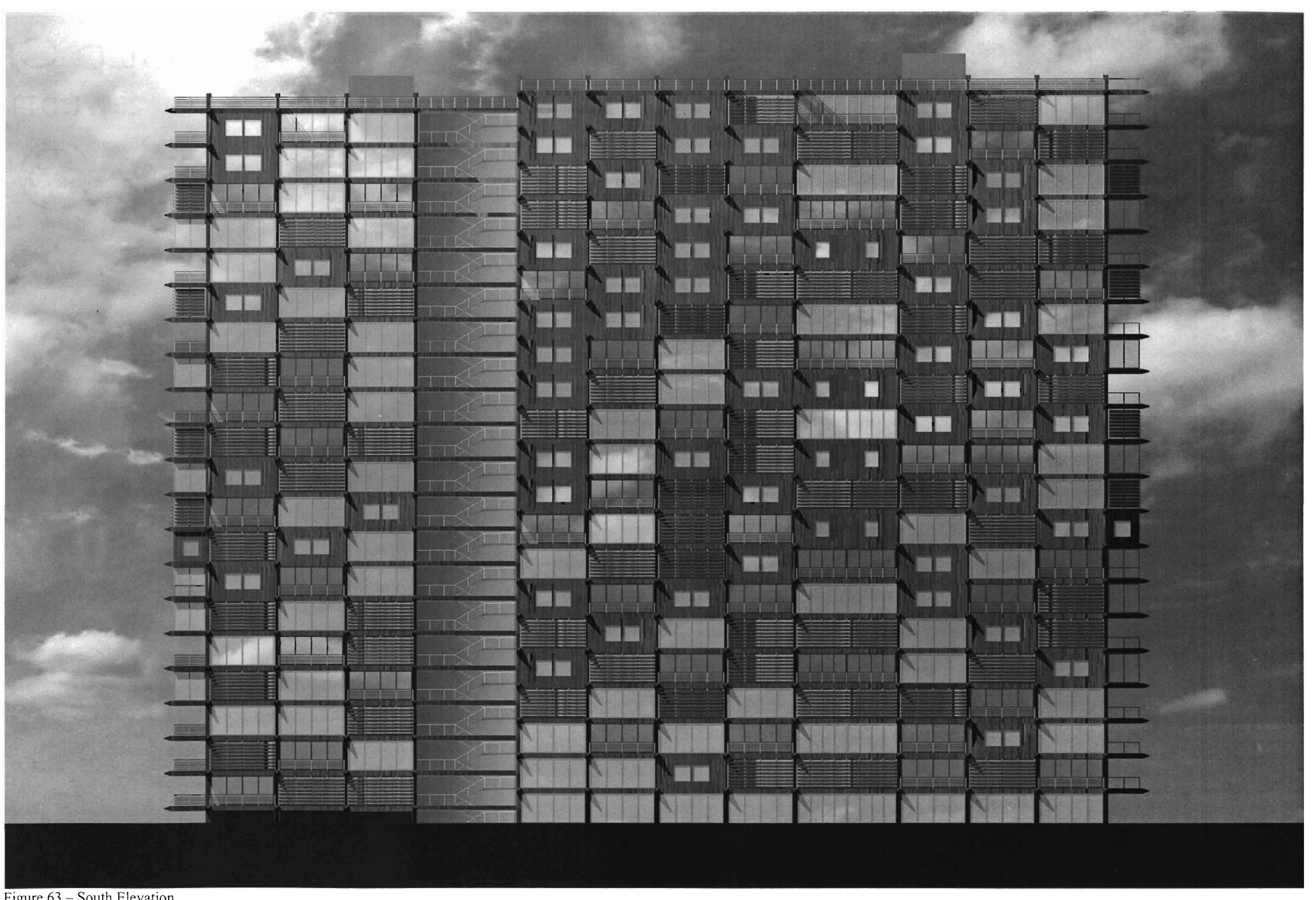




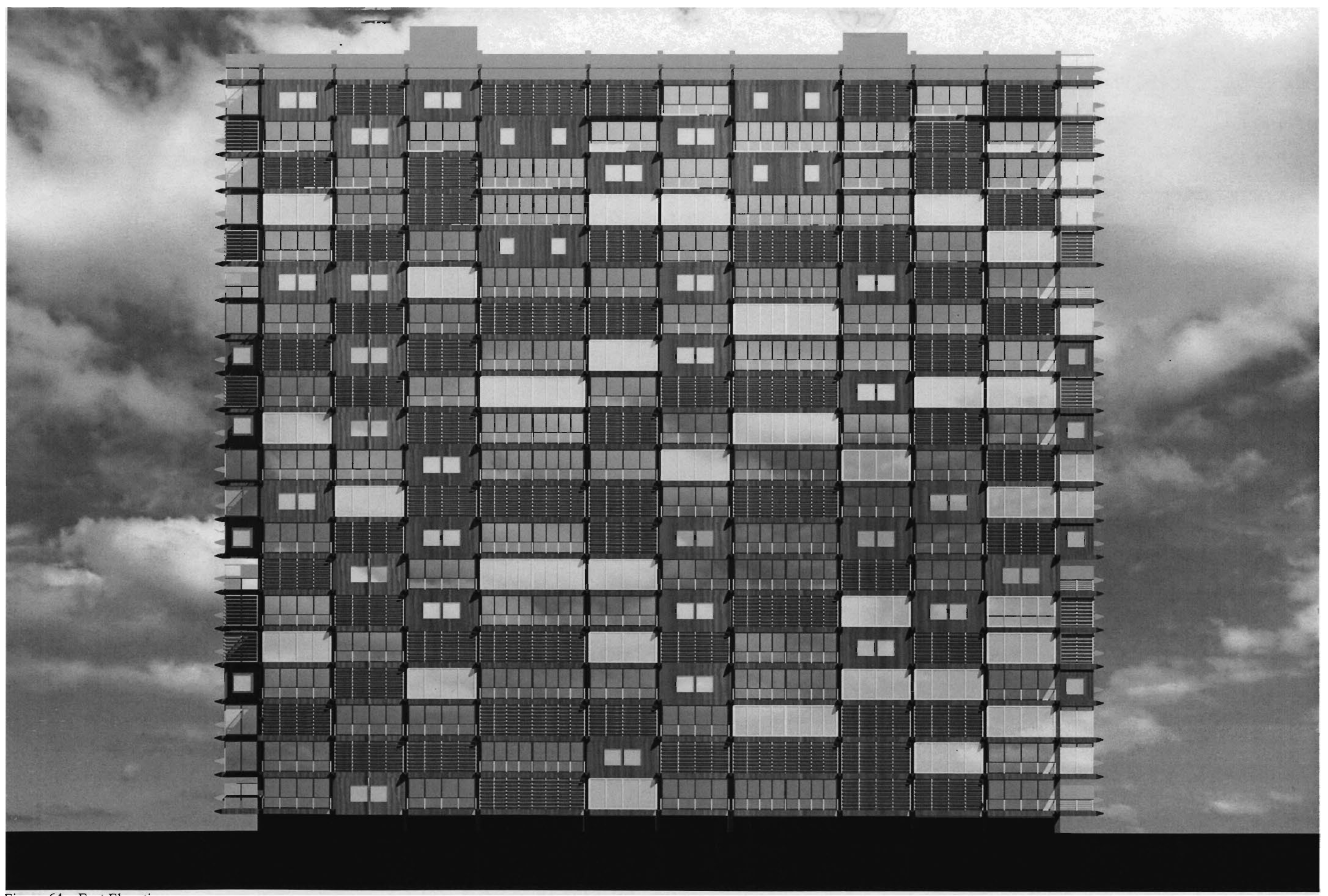




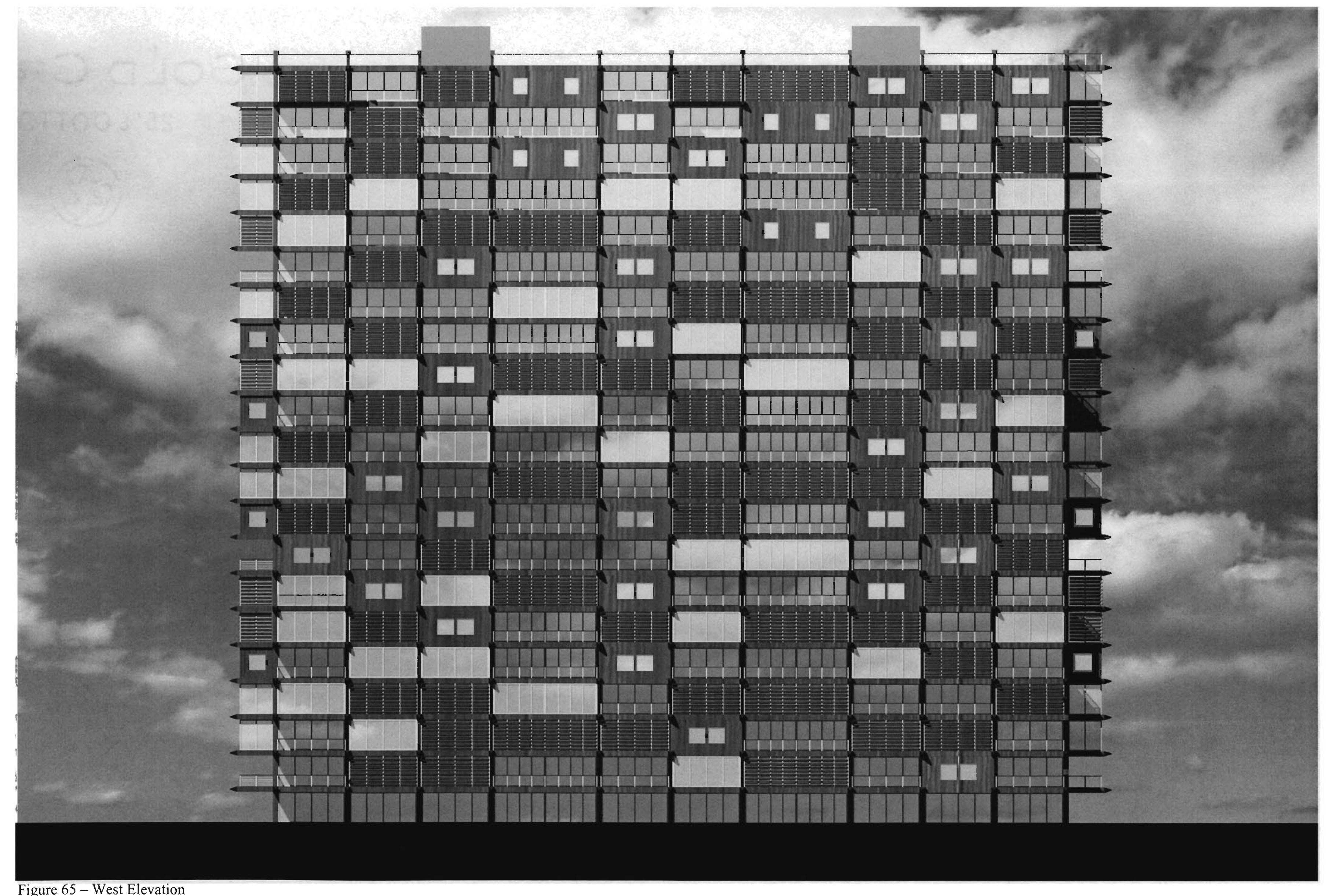




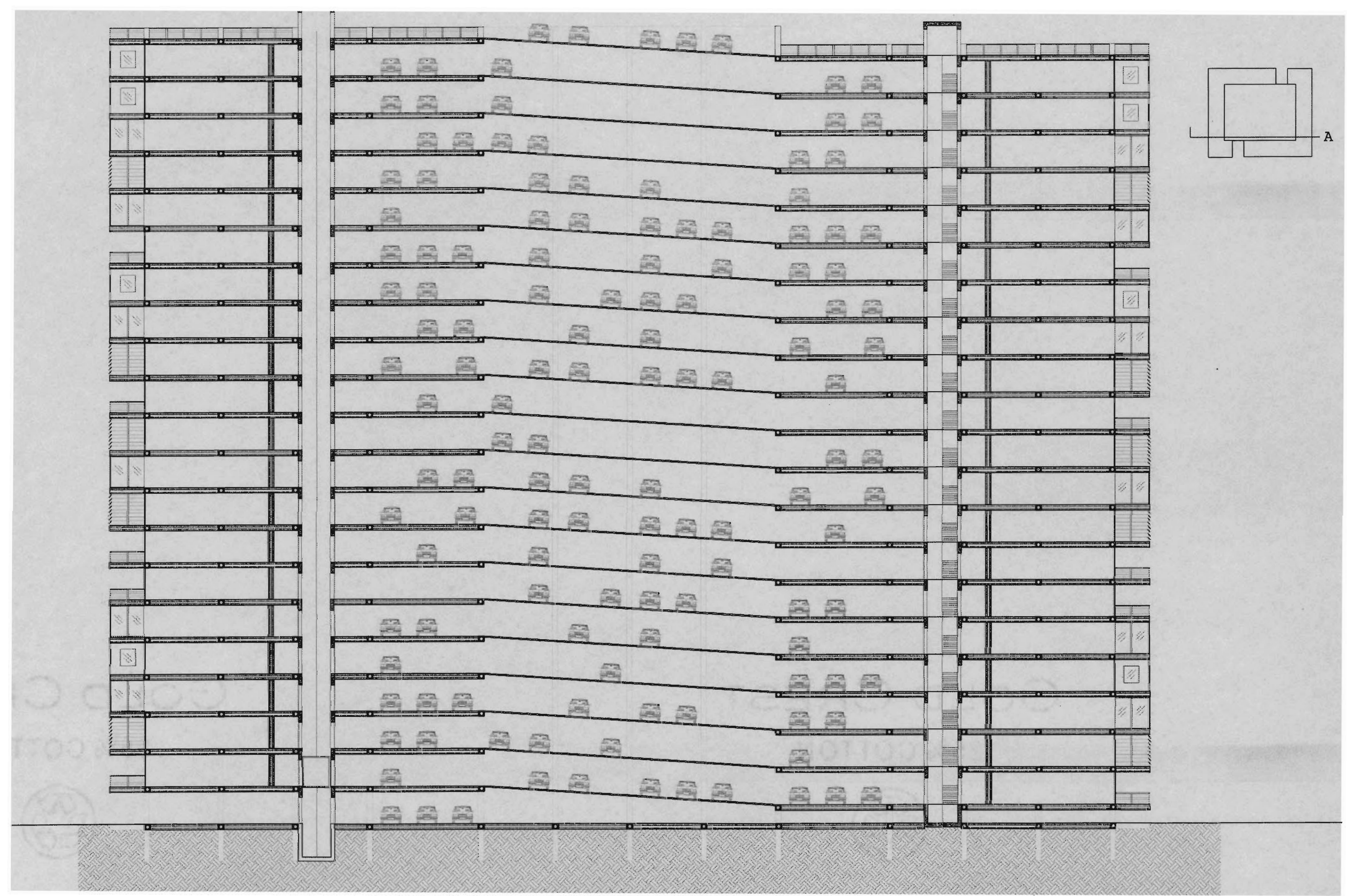




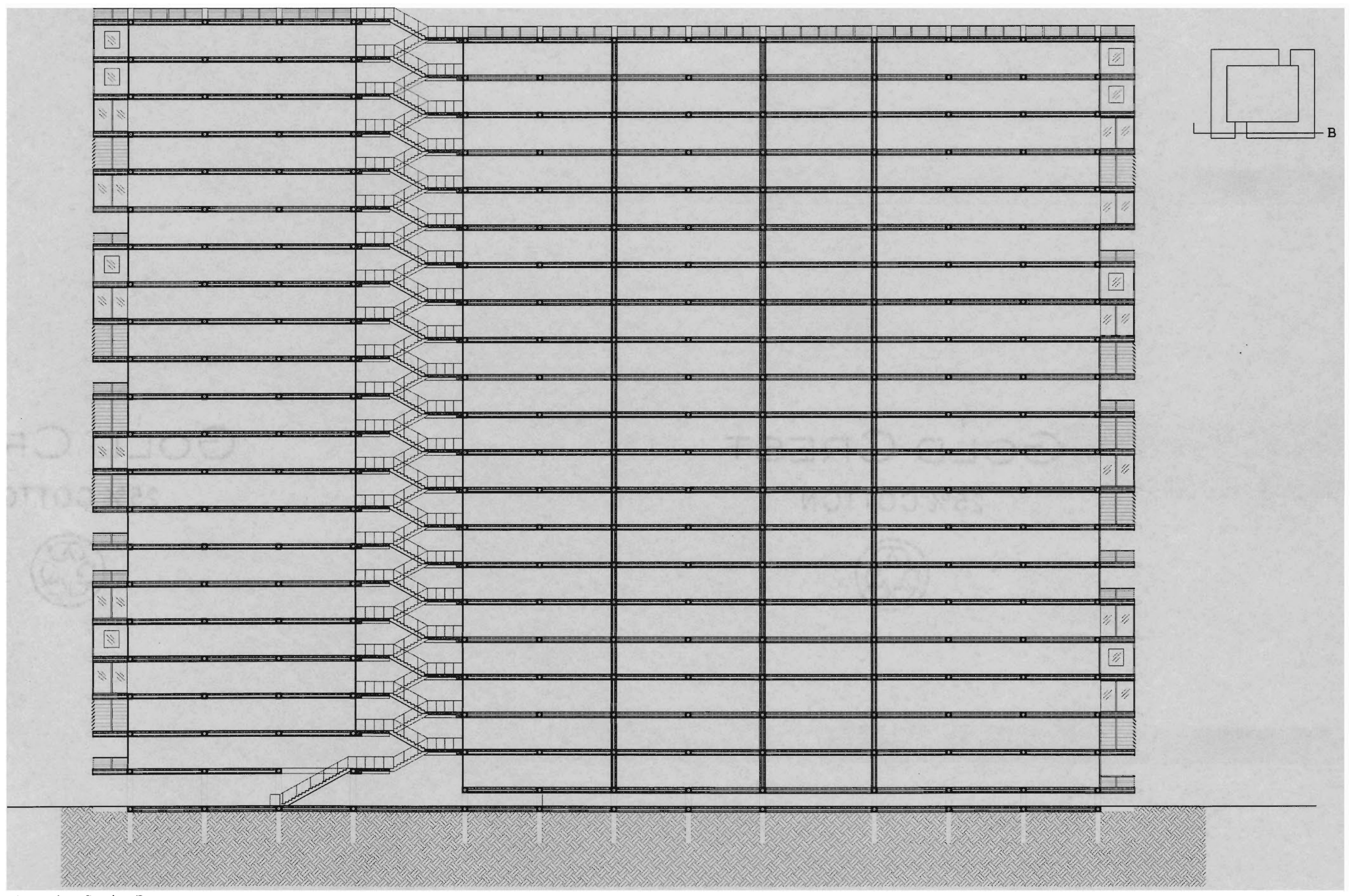




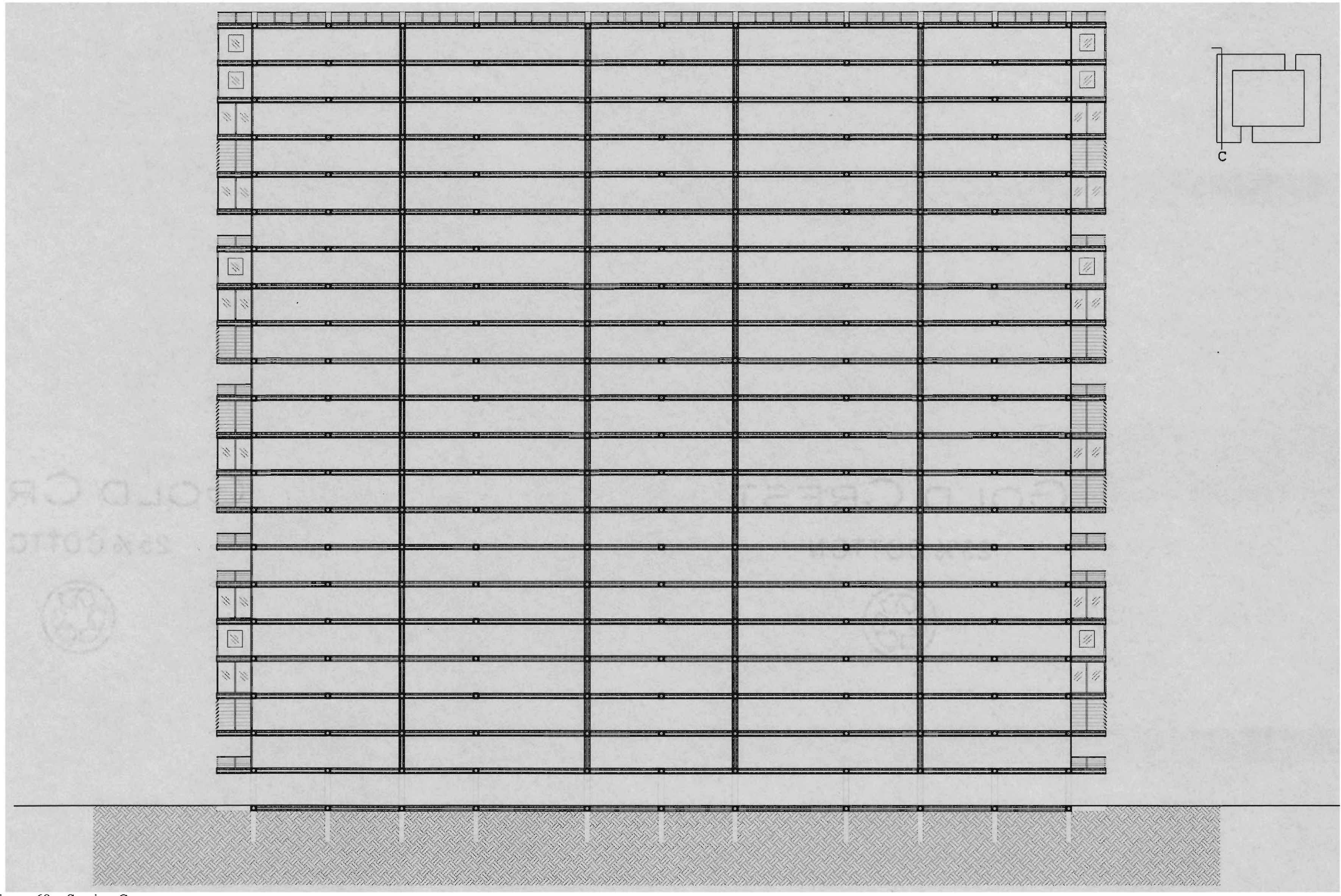

Figure 68 - Section C 


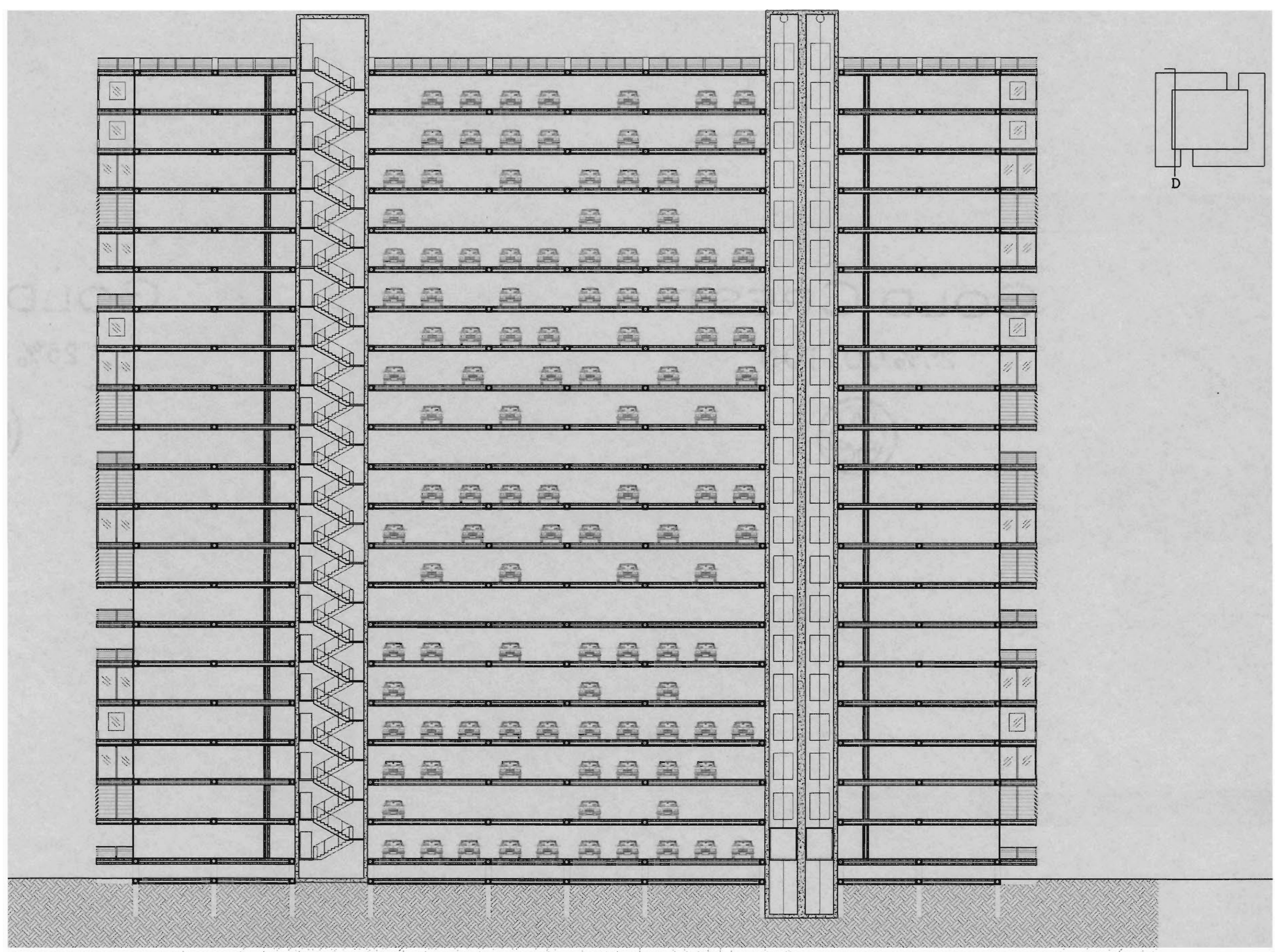




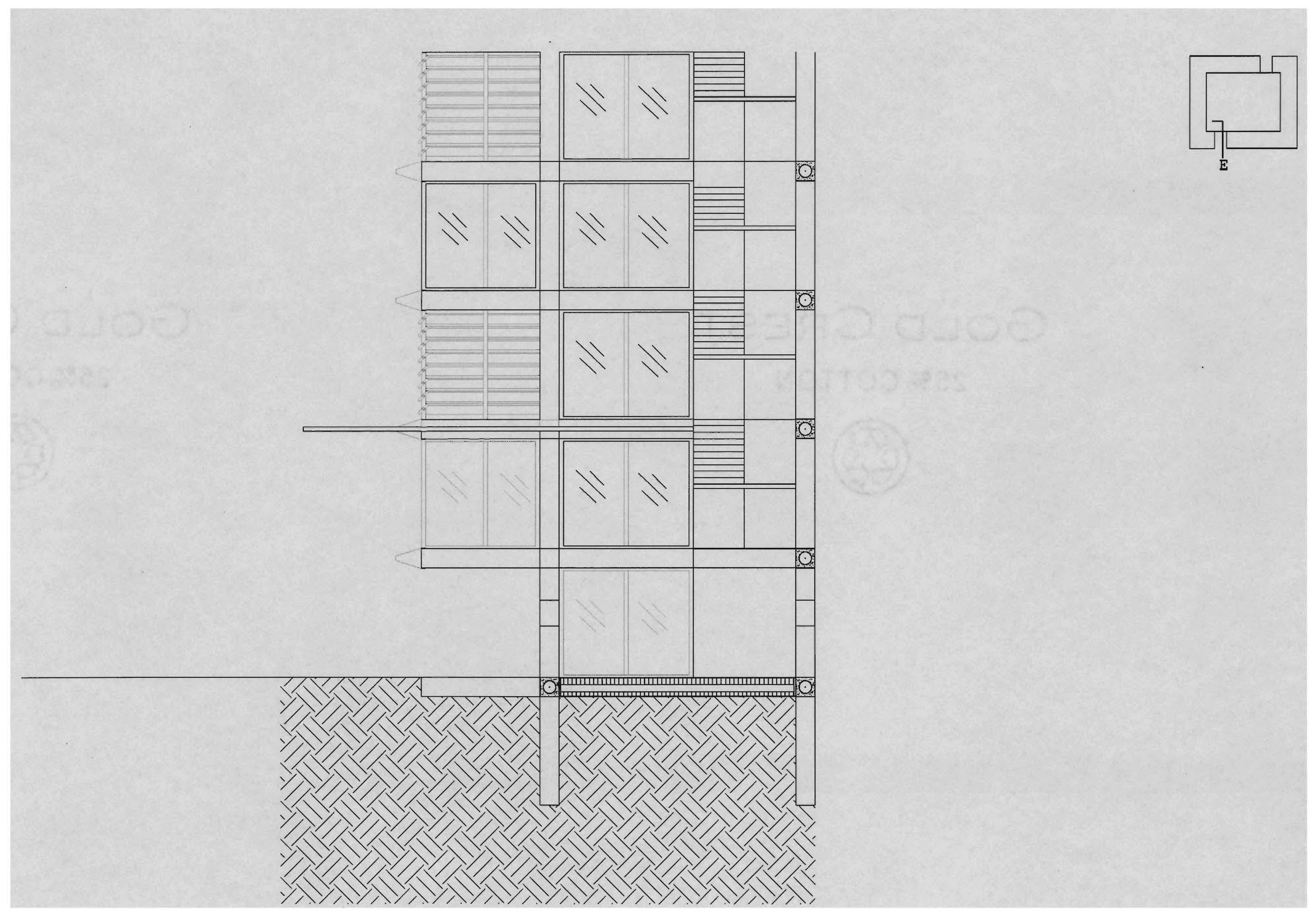


CONCLUSION

What problems in society might this system solve? It is possible that an urban renewal based on an aggressive modular system could begin to counteract urban sprawl.

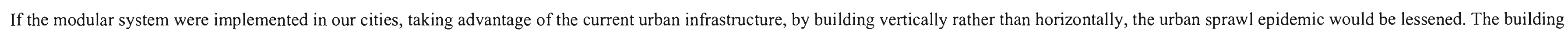

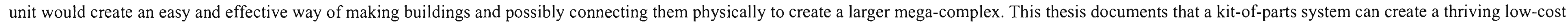
community which is both beneficial to its inhabitants as well as lucrative for its developers.

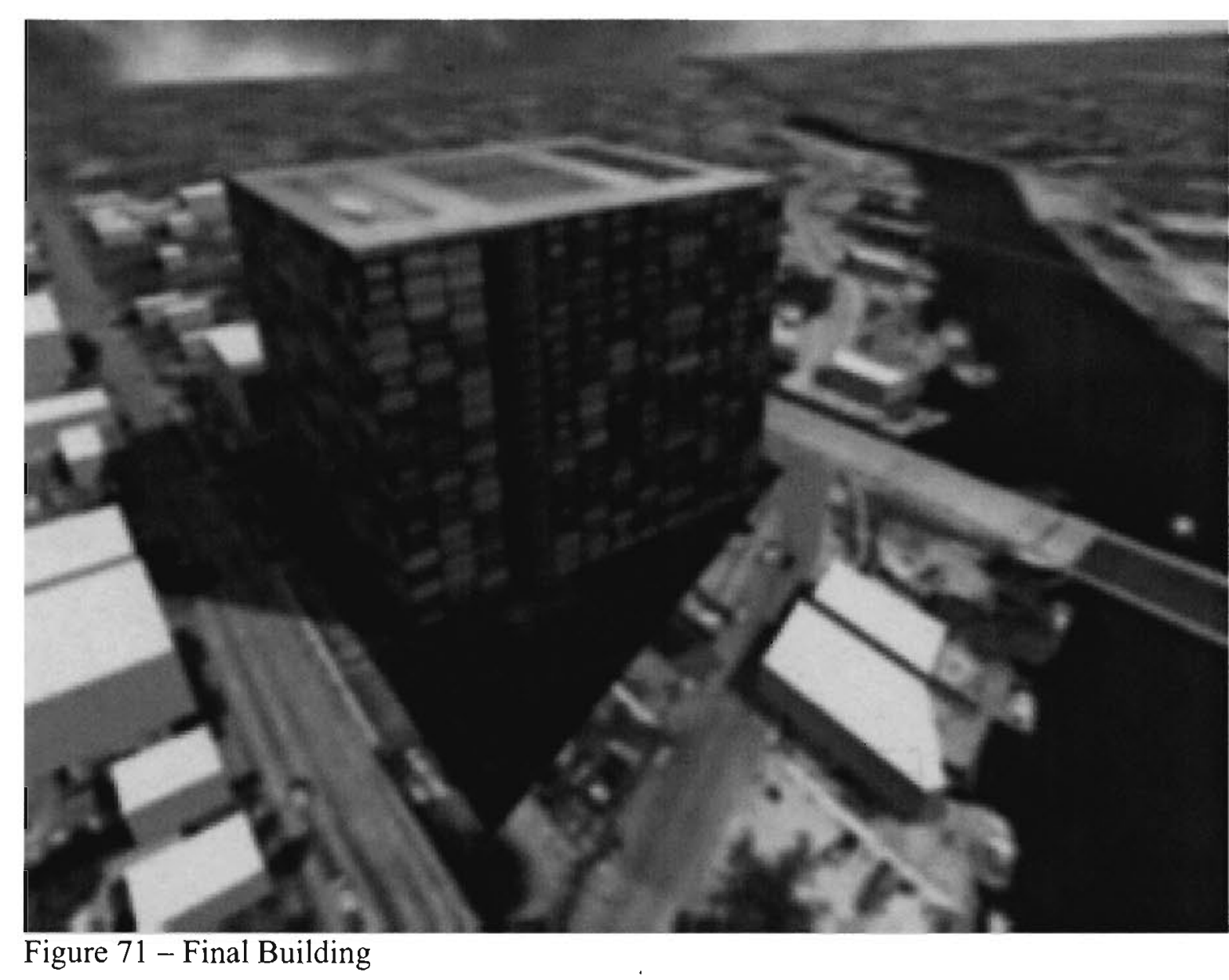


A.E.J. Morris. Pre-cast Concrete in Architecture. New York: Whitney Library of Design, 1978 p.270

Allen, Edmund. Fundamentals in Building Construction Second Edition. New York: Wiley-Interscience, 1990 pp.366,442

Alvarez, Leonardo, Ford, Joseph. Places in Time : Historic Architecture and Landscapes of Miami. Miami, FL : Florida International University, School of Design, c1994.

Burayidi, Michael A.. Downtowns : Revitalizing the Centers of Small Urban Communities. New York : Routledge, 2001.

Dunlop, Beth. Miami : Trends and Traditions New York : Monacelli Press, 1996.

Ebenezer Howard, Frank Lloyd Wright, and Le Corbusier / Robert Fishman. Urban utopias in the twentieth century New York : Basic Books, c1977.

Fritz W. Wagner, Timothy E. Joder, Anthony J. Mumphrey, Jr. Human Capital Investment for Central City Revitalization. New York : Routledge, 2003.

Gosling, David. The Evolution of American Urban Design : a chronological anthology. Chichester ; Hoboken, NJ : Wiley-Academy, 2003.

Gugler, Josef. The Urban Transformation of the Developing World. Oxford ; New York : Oxford University Press, 1996.

Hove, Erik van. Networking neighborhoods. Columbia, S.C. : University of South Carolina Press, c2001

Kenneth Frampton and Yukio Futagawa. Modern Architecture 1851-1945. New York: Rizzoli, 1983

Kolson, Kenneth. Big plans : the Allure and Folly of Urban Design. Baltimore : Johns Hopkins University Press, 2001.

Kurokawa, Kisho. Metabolism in Architecture. London: Studio Vista, 1977. pp.101-103

Le Corbusier. Modular 2. Cambridge, Mass: M.I.T. Press, 1958

Lippman, Katherine M. Downtown Revitalization. Beltsville, Md. : Rural Information Center, National Agricultural Library, [2000]

Manzanilla, Linda. Emergence and Change in Early Urban Societies. New York : Plenum Press, c1997

More, Thomas, Sir, Saint. Utopia. Cambridge, U.K. ; New York : Cambridge University Press, 2002.

Ockman, Joan. Out of Ground Zero : Case Studies in Urban Reinvention. New York : Prestel, c2002.

Powell, Ken. City Transformed : Urban Architecture at the Beginning of the 21st Century. New York : te Neues, 2000.

Patricios, Nicholas N. Building Marvelous Miami. Gainesville : University Press of Florida, c1994

Reyner Banham. Megastructure : Urban Futures of the Recent Past. New York : Harper and Row, 1976

Rothstein, Edward. Visions of Utopia. New York : Oxford University Press, 2003

The Livable City : Revitalizing Urban Communities New York : McGraw Hill, 2000

Von Hoffman, Alexander. House by House, Block by Block : the Rebirth of America's Urban Neighborhoods. Oxford ; New York : Oxford University Press, 2003.

Williams, Donald C. Urban Sprawl : a Reference Handbook. Santa Barbara, Calif. : ABC-CLIO, c2000. 
ENDNOTES

1. Kurokawa, Kisho. Metabolism in Architecture. London: Studio Vista, 1977. pp.101-103

2. Kenneth Frampton and Yukio Futagawa. Modern Architecture 1851-1945. New York: Rizzoli, 1983

3. Edmund Allen. Fundamentals in Building Construction Second Edition. New York: Wiley-Interscience, 1990 pp.366,442

4. A.E.J. Morris. Pre-cast Concrete in Architecture. New York: Whitney Library of Design, 1978 p.270 